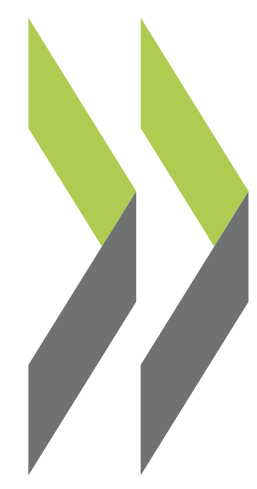

OECD Economics Department Working Papers No. 815

The Impact of Structural Policies on Saving, Investment and Current Accounts

Clovis Kerdrain, Isabell Koske, Isabelle Wanner 
Organisation de Coopération et de Développement Économiques

Organisation for Economic Co-operation and Development

02-Dec-2010

ECONOMICS DEPARTMENT

English - Or. English

Cancels \& replaces the same document of 23 November 2010

THE IMPACT OF STRUCTURAL POLICIES ON SAVING, INVESTMENT

AND CURRENT ACCOUNTS

ECONOMICS DEPARTMENT WORKING PAPERS No. 815

by Clovis Kerdrain, Isabell Koske, Isabelle Wanner

All OECD Economics Department Working Papers are available on the OECD Intranet website at www.oecd.org/eco/workingpapers

JT03293824

Document complet disponible sur OLIS dans son format d'origine

Complete document available on OLIS in its original format 


\section{ABSTRACT/RÉSUMÉ \\ The impact of structural policies on saving, investment and current accounts}

This paper explores the impact of structural policies on saving, investment, and current accounts in OECD and non-OECD economies. Since the current account effects of structural reforms are often complex and ambiguous from a theoretical perspective, new OECD empirical analysis is carried out. Reduced-form equations are estimated for a panel of 30 OECD countries as well as for a panel/cross-section of 117 OECD and nonOECD countries that relate saving, investment and current accounts to policy indicators and a set of macroeconomic control variables. This work suggests that structural reforms may influence saving, investment and current accounts through their impact on macroeconomic conditions such as productivity growth or public revenues and expenditures, but also more directly: $i$ ) higher social spending (in particular on health care) is found to lower the saving rate and thereby to weaken the current account, most likely reflecting lower precautionary saving; ii) product market liberalisation temporarily boosts investment and thus also weakens the current account; iii) financial market deregulation may lower the saving rate, though only in less developed countries; $i v$ ) stricter employment protection may be associated with lower saving rates if unemployment benefits are low, as well as with higher investment rates possibly due to greater substitution of capital for labour. A scenario analysis indicates that fiscal consolidation and structural reforms in the main world economies could significantly reduce current global imbalances, possibly by about a third.

JEL Classification: E21; E22; F41; H55; K31; K20; G18; H23

Key words: Saving; investment; current account; social welfare system; labour market regulation; product market regulation; financial market regulation; taxation

$* * * * *$

\section{L'impact des politiques structurelles sur l'épargne, l'investissement, et la balance courante}

Cet article étudie l'impact des politiques structurelles sur l'épargne, l'investissement, et la balance courante de pays membres et non-membres de l'OCDE. Cette nouvelle étude de l'OCDE en présente une analyse empirique, l'impact des réformes structurelles sur la balance courante étant souvent complexe et ambigu d'un point de vue théorique. L'épargne, l'investissement et la balance courante sont reliés à un ensemble de variables de politiques structurelles par des équations de forme réduite, estimées en incluant des variables macroéconomiques de contrôle. Les régressions sont basées d'une part sur des données de 30 pays de l'OCDE disponibles sur une longue période, et d'autre part sur des séries plus courtes pour 117 pays membres et nonmembres de l'OCDE. Cette étude suggère que les réformes structurelles peuvent influencer l'épargne, l'investissement et la balance courante via leur impact sur les conditions macroéconomiques telles que la croissance de la productivité, les recettes ou les dépenses publiques. Plus directement, elle indique également que $: i$ ) une augmentation des dépenses de protection sociale (en particulier des dépenses de santé) réduit le taux d'épargne, et donc affaiblit la balance courante, reflétant probablement une diminution de l'épargne de précaution; ii) une libéralisation du marché des biens et services augmente temporairement l'investissement, ce qui affaiblit également la balance courante ; iii) une dérégulation des marchés financiers pourrait réduire le taux d'épargne dans les pays les moins développés; $i v$ ) une protection plus stricte des emplois pourrait conduire à une réduction du taux d'épargne lorsque les allocations-chômage sont faibles, ainsi qu'à une élévation du taux d'investissement, peut-être due à une substitution de capital au travail. Les simulations indiquent qu'une consolidation budgétaire et des réformes structurelles dans les principales économies mondiales pourraient réduire significativement les déséquilibres macroéconomiques mondiaux actuels, peut-être d'environ un tiers.

Classification JEL : E21 ; E22 ; F41 ; H55 ; K31 ; K20 ; G18 ; H23

Mots-Clés : Epargne ;investissement; balance courante ; système de protection sociale ; régulation du marché du travail ; régulation du marché des biens et services ; régulation des marchés financiers ; fiscalité

Copyright $\odot$ OECD, 2010. All rights reserved. Application for permission to reproduce or translate all, or part of, this material should be made to: Head of Publications Service, OECD, 2 rue André-Pascal, 75775 PARIS CEDEX 16, France. 


\section{TABLE OF CONTENTS}

\section{THE IMPACT OF STRUCTURAL POLICIES ON SAVING, INVESTMENT

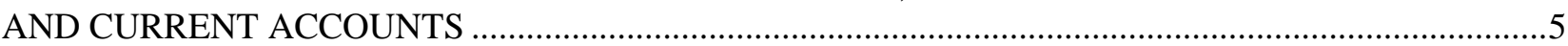

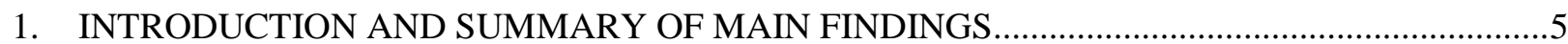

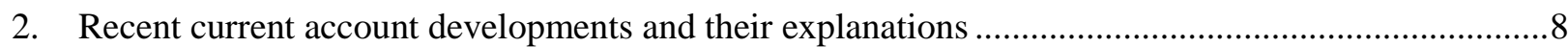

3. Structural policy reforms and current accounts: some theoretical links ........................................11

3.1. Theoretical linkages between structural reforms and saving ..................................................11

3.2. Theoretical linkages between structural reforms and investment .......................................... 14

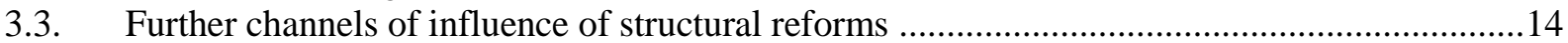

4. Empirical analysis of the effect of structural policies on saving, investment

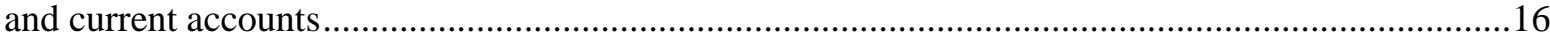

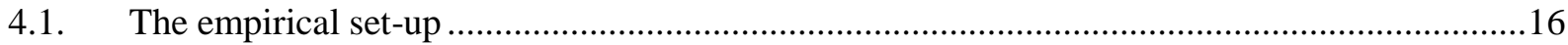

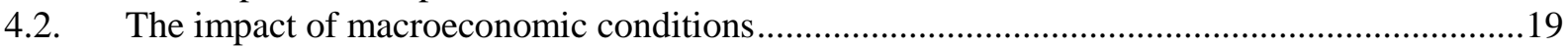

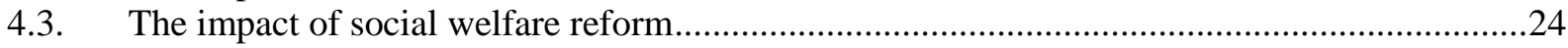

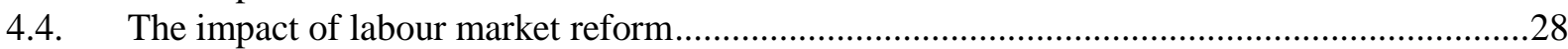

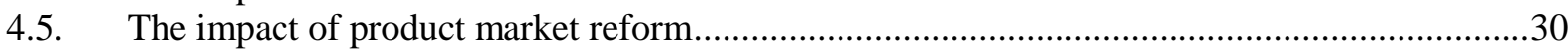

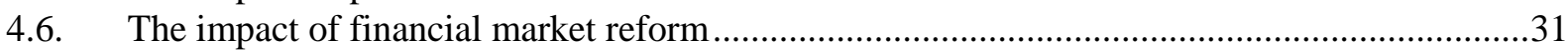

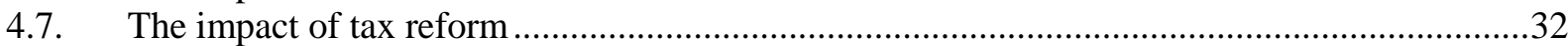

5. Quantifying the impact of policy reforms on current account imbalances ......................................33

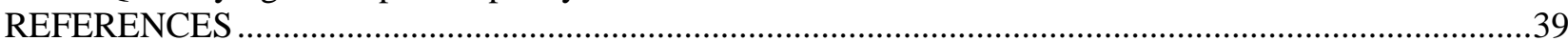

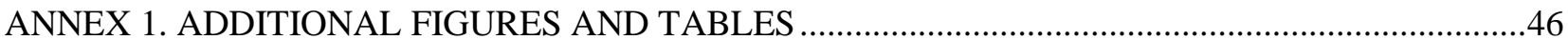

ANNEX 2. DEALING WITH (ALMOST) TIME-INVARIANT EXPLANATORY VARIABLES ...........65

\section{Tables}

1. Baseline estimation results for OECD sample 1965-2008 …..............................................22

2. Baseline estimation results for OECD/non-OECD sample ..............................................23

3. The impact of structural policies on saving, investment and current accounts

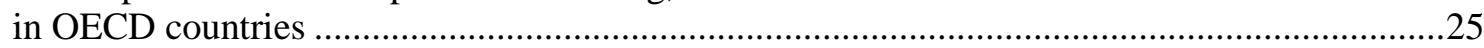

4. The impact of structural policies on saving, investment and current accounts - OECD/non-

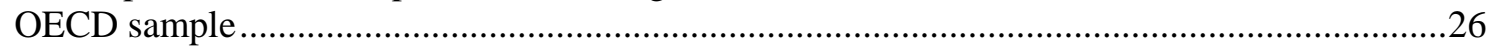

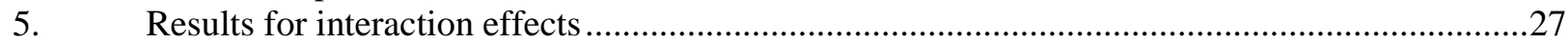

6. Overview of the estimated effects of structural policies on saving, investment

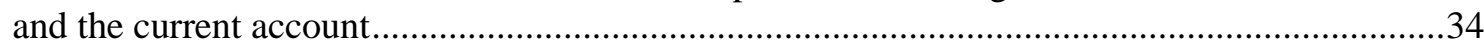

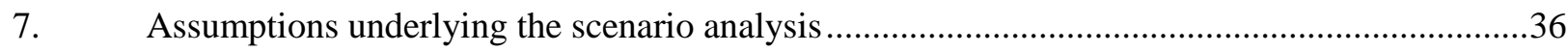

A1.1. Data definition and sources - OECD dataset ........................................................................54

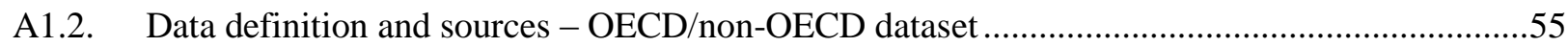

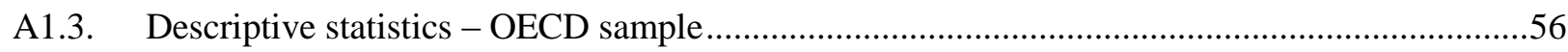

A1.4. Panel unit root tests for dependent and macroeconomic control variables

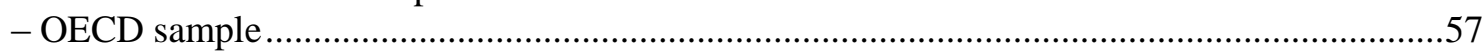

A1.5. Baseline estimation results for OECD sample 1965-2008 - country fixed effects and time trends 
A1.6. Baseline estimation results for OECD sample 1965-2008 - exclusion of influential data points

A1.7. Alternative baseline estimation results for OECD sample 1965-2008 ....

A1.8. The impact of structural policies on saving, investment and current accounts in OECD countries- country fixed effects and time trends

A1.9. The impact of structural policies on saving, investment and current accounts in OECD countries - exclusion of influential data points ....

A1.10. The impact of structural policies on saving in OECD countries - alternative specifications

A1.11. The impact of structural policies on investment in OECD countries

- alternative specifications

\section{Figures}

1. Global imbalances 1990-2008 .8

2. Saving and investment developments in selected countries and regions....................................

3. Results for interaction effects - OECD/non-OECD sample..................................................28

4. Simulated current account impact of illustrative structural reforms and fiscal consolidation scenarios

5. Simulated impact of structural reforms and fiscal consolidation on a summary measure of

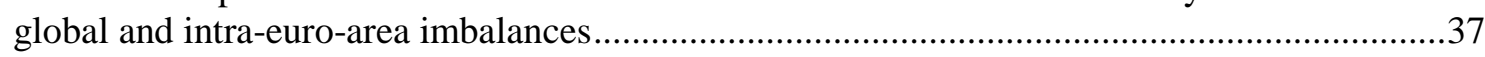

A1.1. In-sample and out-of sample forecasting properties of baseline saving rate specifications -

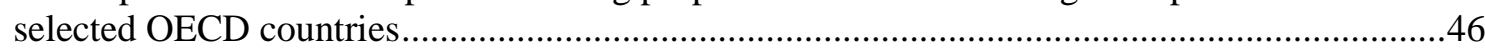

A1.2. In-sample and out-of sample forecasting properties of baseline investment rate specifications -

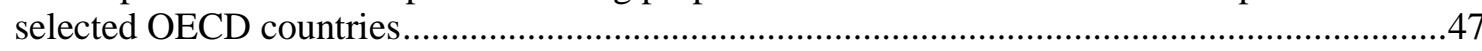

A1.3. Robustness of estimation results to variations in the set of countries included in the sample total saving rate...

A1.3. Robustness of estimation results to variations in the set of countries included in the sample total saving rate (cont.)

A1.4. Robustness of estimation results to variations in the set of countries included in the sample -

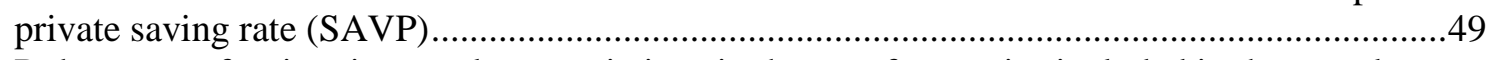

A1.4. Robustness of estimation results to variations in the set of countries included in the sample -

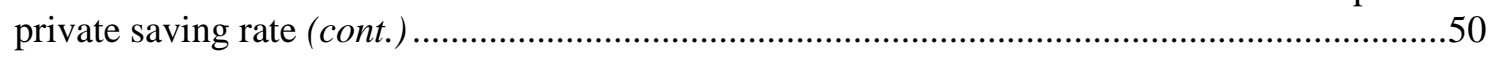

A1.5. Robustness of estimation results to variations in the set of countries included in the sample total investment rate ......................................................................................................... 51

A1.6. Robustness of estimation results to variations in the set of countries included in the sample -

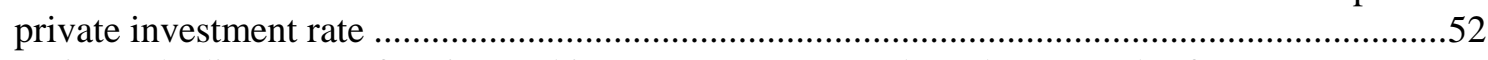

A1.7. Estimated adjustment of saving and investment rates to selected structural reforms ..................53

\section{Boxes}

Box 1. The theoretical impact of productivity shocks on saving and the current account........................13

Box 2. Details on the empirical set-up..... 
ECO/WKP(2010)71

\title{
THE IMPACT OF STRUCTURAL POLICIES ON SAVING, INVESTMENT AND CURRENT ACCOUNTS
}

\author{
by \\ Clovis Kerdrain, Isabell Koske, Isabelle Wanner ${ }^{1}$
}

\section{INTRODUCTION AND SUMMARY OF MAIN FINDINGS}

1. Global saving and investment imbalances had widened markedly in the years prior to the crisis, involving both OECD countries and non-OECD countries. Though the crisis brought some reversal of this trend with current account imbalances narrowing from around mid-2007 to mid-2009, the recent upswing was accompanied by a renewed widening of global imbalances. Under unchanged policies the decline in national saving-investment gaps is thus likely to have been at least partially a temporary phenomenon, and the issue of imbalances is set to return in the medium to long run.

2. Current accounts result from global general equilibrium conditions that are driven by multiple factors, including domestic structural policy settings in financial, product and labour markets as well as tax and social welfare systems. ${ }^{2}$ While the primary goal of structural reforms is not to address global savinginvestment imbalances, they can have more or less persistent side effects on the saving and investment decisions of households and firms as well as on public saving and investment. Against this background, this paper investigates the relationship between structural policies and saving, investment, and current account balances, focusing on five different policy areas: social welfare systems, labour market policy, product market regulation, financial market regulation, and tax policy. With this focus in mind, the paper does not explore the drivers of global current account imbalances in general, nor does it assess the extent to which they represent disequilibria.

3. The discussion in this paper is positive in the sense that it assesses the likely impact of structural policies on the saving and investment behaviour of private agents, and thereby on current accounts, without addressing the desirability of policy changes. To the extent that national saving-investment gaps are the result of utility-maximising behaviour in the absence of any distortions - for example, they could reflect a desire by households to smooth consumption over time -, the rationale for policy intervention might only be found by assessing whether these gaps cause any global or systemic risk, which is not within the scope of this paper. But it may also be the case that the gaps reflect underlying domestic distortions, which can be narrowed by domestic policy interventions. Even so, the goal of such interventions should be to maximise overall welfare, not to reduce saving-investment gaps per se. In fact, removing distortions to increase welfare may narrow or widen national saving-investment gaps, depending on the type of the distortion.

1. At the time of writing all authors were members of the Structural Surveillance Division of the OECD Economics Department. They would like to thank Jørgen Elmeskov, Jean-Luc Schneider, Romain Duval and Jean-Marc Fournier for their valuable inputs, suggestions and comments as well as Celia Rutkoski and Olivier Besson for excellent editing support. Any errors are the responsibilities of the authors alone. The views expressed in this paper are those of the authors, and do not necessarily reflect those of the OECD or its member countries.

2. Within the scope of this paper, structural policy reforms are defined as all reforms that may enhance longrun living standards, as analysed for instance by the OECD in its Going for Growth process. 
4. The present study investigates the link between domestic structural policies and the GDP shares of saving, investment and the current account both from a theoretical and an empirical perspective. In the empirical part, a set of reduced-form equations are estimated for a panel of 30 OECD countries as well as for a panel/cross-section of 117 OECD and non-OECD countries that relate the GDP shares of respectively saving, investment and the current account balance to policy indicators and a set of control variables. The following main conclusions emerge from the analysis:

- Theoretically, structural policies can influence the saving and investment decisions of firms and households through a variety of different channels. To the extent that households attempt to smooth consumption over time, any reform that affects temporarily the growth of income or the real rate of interest should temporarily influence the saving rate of households. Moreover, policies may affect the precautionary saving behaviour of households by altering the level of uncertainty they are facing and/or their insurance against adverse events (though the saving rate should change only temporarily as a result, until the new optimal precautionary wealth stock is reached). The investment rate, in turn, should be influenced by all policies that affect the cost of capital and/or the return on investment projects. Due to the wide range of different channels and the complex interactions between them, the sign and the size of the link between structural policies and saving and investment remain largely an empirical question.

- The empirical analysis suggests that structural policy reforms may influence saving and investment by altering macroeconomic conditions. In particular, policies that foster productivity growth are found to lead to a boost in saving and investment ratios in the medium to long-run. The relative size of the estimated coefficients on productivity growth hints at a negative net impact of productivity-enhancing reforms on the current account position through this channel. Similarly, policy reforms that involve changes in public revenues and expenditures and are fiscally non-neutral will alter a country's total saving rate and thereby its current account, reflecting evidence that Ricardian equivalence holds only partially.

- There is some evidence that structural policies have an influence on saving and investment on top of any impact that works through changes in these macroeconomic conditions. First, there is evidence that higher social spending (in particular on health care) is associated with a lower saving rate and a weaker current account, most likely reflecting lower precautionary saving of households. Second, there are some indications that removing competition-unfriendly product market regulation boosts investment, though this effect is likely to be only temporary. Third, financial market deregulation tends to lower the saving rate in less developed countries. Fourth, stricter employment protection legislation (EPL) may be associated with lower saving rates, but only in countries where unemployment benefits are low. Stricter EPL also appears to raise the investment rate, at least in OECD countries, possibly linked to greater substitution of capital for labour. Fifth, while no robust effects of tax reforms on investment rates could be discerned here using aggregate macroeconomic data, existing firm and sector-level evidence suggests that a lower tax burden on firms boosts business investment and thereby weakens the current account.

- The empirical analysis also gives some insights into which potential links between structural policies and saving and investment rates might be less relevant in practice. In particular, while deregulated financial markets could in theory strengthen the current account effects of other reforms by facilitating consumption smoothing, the empirical analysis does not provide any evidence that financial market reforms alter the impact of other policy reforms on the saving and investment behaviour of private agents. Also, there is no evidence that structural policies influence the speed at which firms and households adjust their saving and investment behaviour in response to changes in macroeconomic conditions. 
5. The analysis suggests that a number of structural reforms that are desirable on efficiency and/or welfare and equity grounds would be associated with a reduction of global imbalances by narrowing the gaps between domestic saving and investment in several major economic areas. In particular:

- Developing social welfare systems in China and other Asian economies would fulfil an important social goal in its own right, and as a side-effect would reduce the need for precautionary saving. This would moderate current account imbalances in those countries that are running surpluses. The empirical estimates suggest, for example, that all else equal a financed increase in public social spending on health in China by 1 percentage point of GDP might reduce total saving by as much as $2^{1 / 2}$ percentage points of GDP (though the standard deviation around this point estimate is 0.9 ).

- Reforms to improve the sustainability of pension systems will reduce current account surpluses (or raise deficits) if they increase the length of the working life and have the opposite effect if they take the form of cuts in replacement rates.

- Removing competition-unfriendly product market regulation could encourage higher capital spending. The empirical analysis suggests, for example, that aligning the level of economy-wide product market regulation in Japan and Germany with OECD best practice could raise private investment in these countries by respectively 0.15 and 0.25 percentage points of GDP in the short run.

- Financial market reforms that raise the sophistication and/or depth of financial markets may relax borrowing constraints in emerging economies and thus help to reduce the high saving rates observed in some of them. For example, if China implemented reforms that led to a liberalisation of its financial system similar in magnitude to that achieved over 1995-2005, the total saving rate could drop by over 3 percentage points of GDP.

- The removal of policy distortions that encourage consumption, such as tax deduction of interest payments on mortgages in the absence of taxation of imputed rent, might help increase household saving in a number of countries, including the United States.

- While structural reforms can contribute to reducing current account imbalances in countries that are running surpluses, their potential to reduce imbalances in deficit countries is found to be more limited. In the latter group of countries, other policy actions that are desirable per se, such as fiscal consolidation, could help achieve a more balanced external position.

- A scenario analysis indicates that the necessary fiscal tightening required to stabilise debt-toGDP ratios in OECD countries by 2025 could reduce the size of global imbalances - measured as the GDP-weighted sum of countries' absolute saving-investment-gap-to-GDP ratios - by almost one-sixth. If, in addition, Japan, Germany and China were to deregulate their product markets and China were to raise public health spending by 2 percentage points of GDP (in a fiscally neutral way) and liberalize its financial markets, global imbalances could decline by twice as much.

- While the fiscal tightening assumed in the scenario analysis would also contribute to a narrowing of intra-euro-area imbalances, the size of the effect would be more muted. A lowering of employment protection in Spain, Portugal and Greece would also only slightly reduce the overall size of intra-euro-area imbalances, but saving-investment gaps of these three countries would fall considerably. 
6. The remainder of this document is structured as follows: Section 2 starts with a brief overview of recent aggregate saving, investment and current account developments, focusing on those countries and regions that have contributed most to global current account imbalances. Section 3 then outlines the main theoretical channels through which structural policies may influence private saving and investment behaviour. Section 4 discusses existing evidence on these channels and presents new empirical results regarding the impact of structural policy changes on saving, investment and current accounts. These results are then used in Section 5 to simulate the impact of possible policy reform packages on global and intraeuro-area imbalances.

\section{Recent current account developments and their explanations}

7. Global current account imbalances had widened markedly in the years preceding the crisis with the United States the main contributor on the deficit side and several of the fast-growing Asian and oilproducing countries as well as Japan and Germany the main contributors on the surplus side (Figures 1 and 2). While the euro area's current account balance with the rest of the world was relatively small, a number of individual member countries recorded sizeable and growing deficits (in particular Greece, Portugal and Spain) or surpluses (next to Germany, mainly the Netherlands). Examining changes in saving and investment patterns highlights that rising saving rates in surplus countries and falling saving rates in deficit countries were the dominant driver behind the divergence in current account positions. In the United States, total saving dropped by around 31/2 percentage points between the mid-1990s and 2007, while in China and oil producing countries the total saving rate rose by about 15 percentage points of GDP over the same period. A few countries have also experienced sizable changes in investment rates. These include in particular Japan, where total investment has fallen by about 10 percentage points of GDP over the past two decades, and Spain, where it has risen by the same amount between the mid-1990s and 2007, before beginning to fall back sharply.

Figure 1. Global imbalances 1990-2008

Current account balances, \% of world GDP

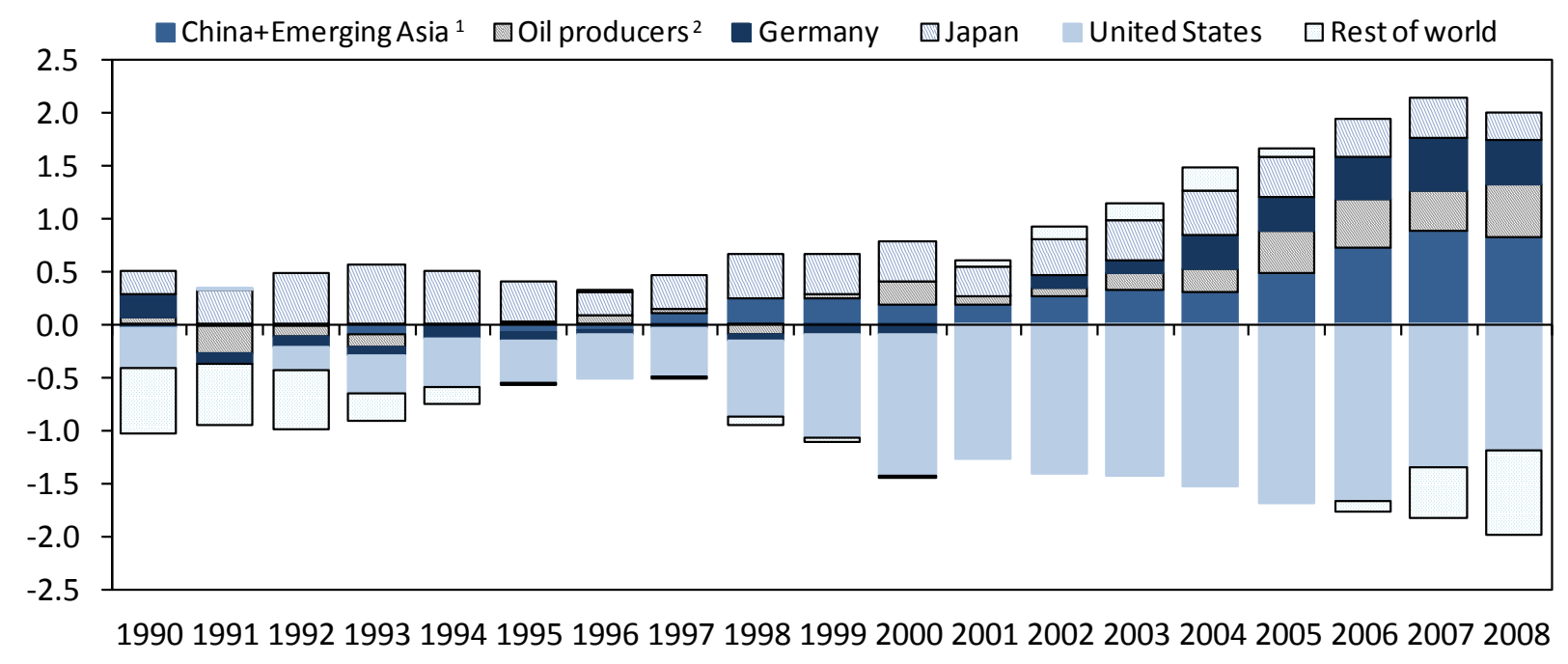

Note: $\quad$ 1. Hong Kong (SAR China), Malaysia, Philippines, Singapore, Vietnam, Thailand, India, Indonesia.

2. Azerbaijan, Kazakhstan, Brunei Darussalam, Bahrain, Iran, Kuwait, Oman, Libya, Yemen, Ecuador, Trinidad and Tobago, Venezuela, Angola, Congo, Gabon, Sudan, Saudi Arabia. 
Figure 2. Saving and investment developments in selected countries and regions $\%$ of GDP

Current account (right scale)

Total saving (left scale)

Total investment (left scale)
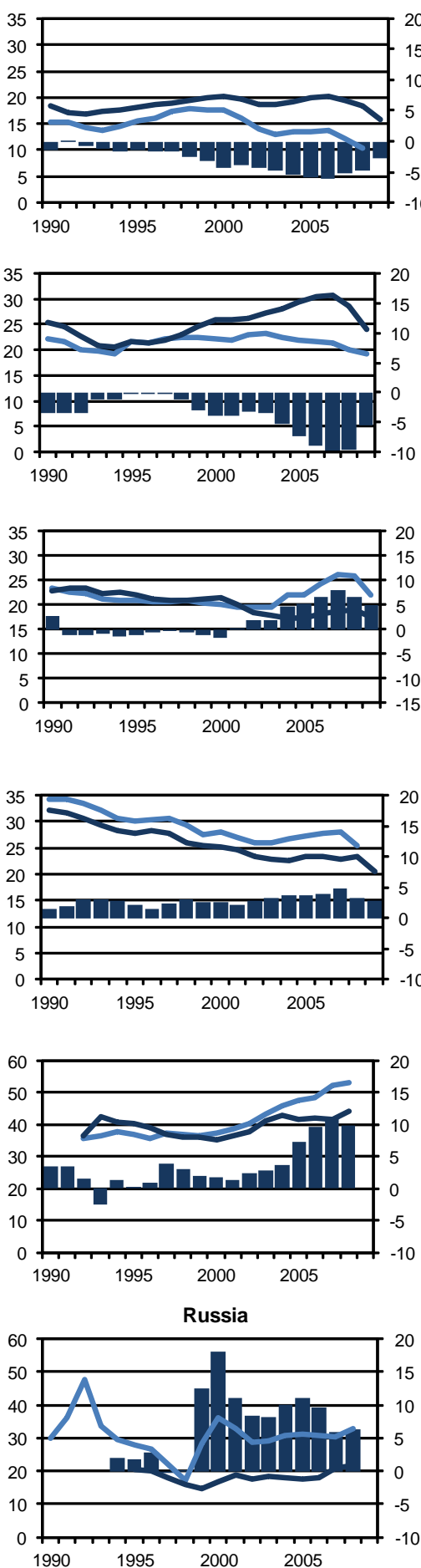

Household saving Business saving

Public saving Total saving

United States
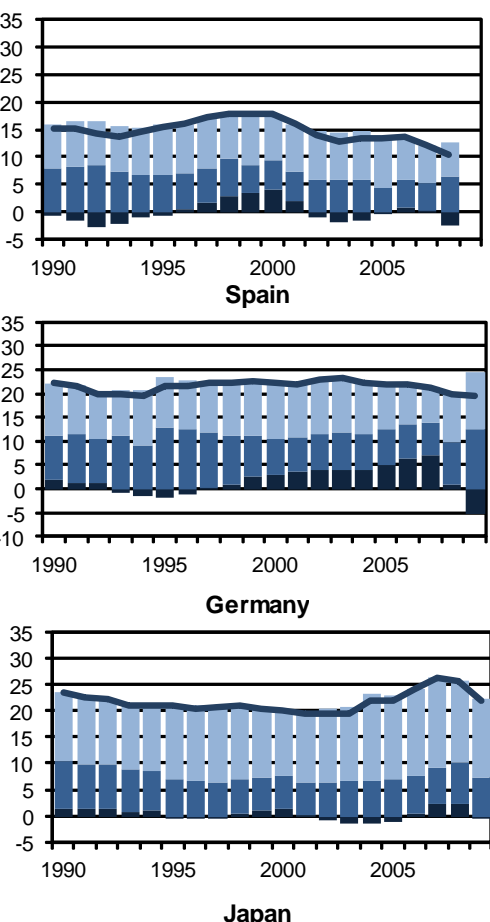

Japan
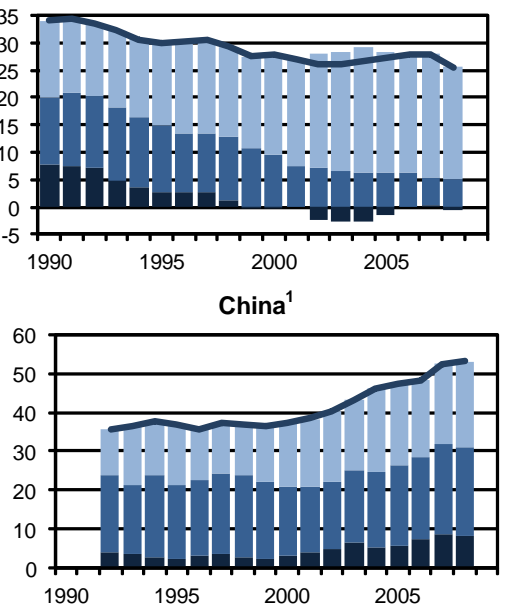

Oil producers ${ }^{2}$

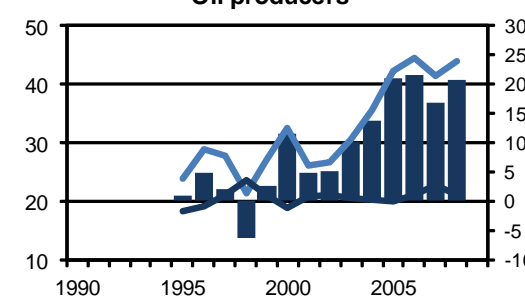

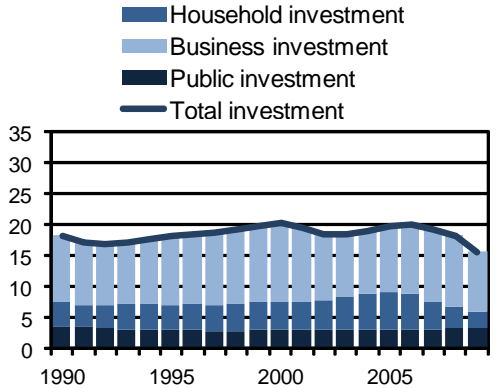
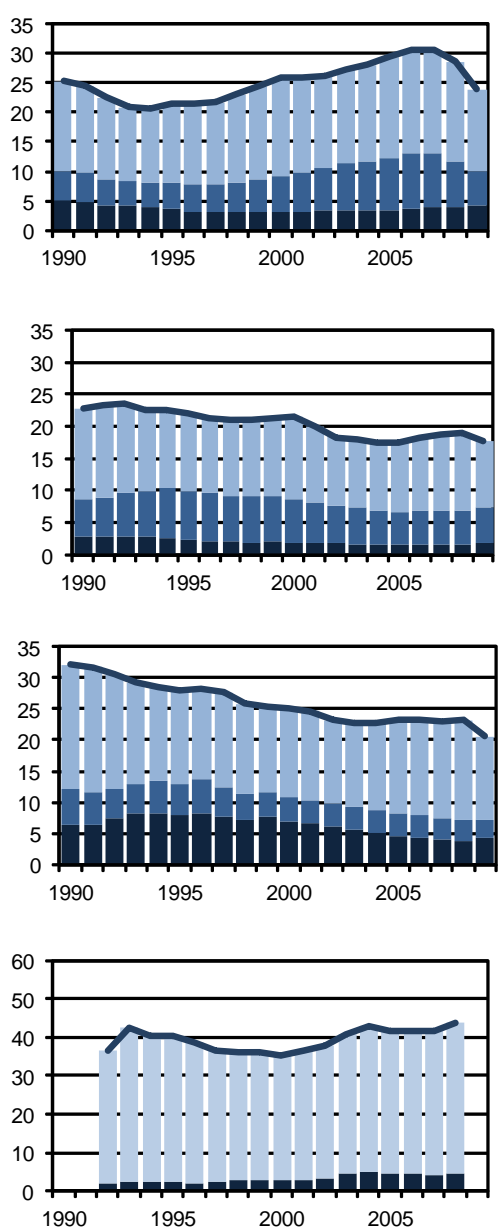

Emerging Asia $^{3}$

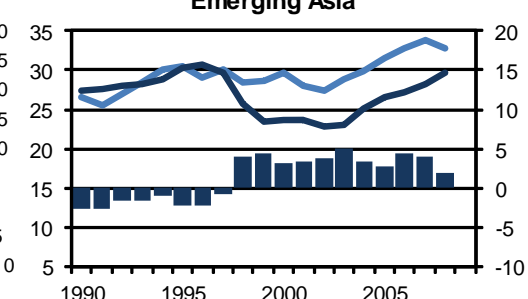

Note: $\quad 1 . \quad$ Only private (light blue) and public (dark blue) investment rates are shown.

2. Azerbaijan, Kazakhstan, Brunei Darussalam, Bahrain, Iran, Kuwait, Oman, Libya, Yemen, Ecuador, Trinidad and Tobago, Venezuela, Angola, Congo, Gabon, Sudan, Saudi Arabia.

3. Hong Kong (SAR China), Malaysia, Philippines, Singapore, Vietnam, Thailand, India, Indonesia. 
8. These persistent saving-investment gaps are reflected in international capital flowing mainly from emerging markets in Asia and oil producing countries towards advanced economies, in particular the United States. This direction of capital flows is surprising at first glance since higher expected (marginal) rates of return would imply that emerging markets should instead attract capital from advanced countries. A number of explanations have been put forward to explain the global widening of saving-investment imbalances as well as the implied direction of capital flows (see e.g. Bracke et al., 2008, for an overview). Most of these explanations take a macroeconomic perspective and do not allow for a major role of structural policy settings - with the exception of financial market regulation. The main arguments put forward include the following:

- The series of financial crises that struck some emerging and developing countries in the late 1990s and early 2000s: In the aftermath of these crises, most emerging countries - including those that had escaped crisis like China - began to build up large foreign exchange reserves as an insurance device against the risk of balance-of-payments crises (Bernanke, 2005; Gruber and Kamin, 2007; Jeanne and Ranciere, 2008).

- $\quad$ The surge in oil prices which boosted income in oil-exporting countries: To the extent that oilexporting countries attempt to smooth consumption over time, this rise in their income may explain the pick-up in total saving, in particularly since these countries are extracting a finite resource. ${ }^{3}$ Together with the lack of domestic investment opportunities, this surge in saving resulted in net capital outflows.

- Insufficient financial market development in many fast-growing emerging countries: Regional financial market imperfections, together with an increasing demand for a store of value, may have resulted in an insufficient supply of safe assets and triggered net capital flows to regions where safe assets were perceived to be produced, notably the United States (Caballero et al., 2008; Caballero and Krishnamurthy, 2009). By creating borrowing constraints, the financial market imperfections may also have prevented households in emerging markets from borrowing against future income (Ju and Wei, 2006).

- "Dark matter": Official statistics may overstate the US net foreign debt by not properly accounting for US intangible assets such as insurance services (safe investments) and knowledge services (organizational knowledge and brand recognition). The argument is based on the observation that US net interest income from abroad has remained positive, meaning that US foreign investments, properly measured at their income-generating capacity, must exceed US foreign investors' claims on the United States (Hausmann and Sturzenneger, 2005).

- Other factors that are likely to have played at least some role include: $i$ ) the decline in business cycle volatility in many developed countries prior to the crisis, which might have been perceived as permanent by households thus inducing them to reduce their precautionary savings (Fogli and Perri, 2006); ii) asset price booms, partly related to low interest rates against a background of low business cycle and inflation volatility, ${ }^{4}$ which may have pushed down saving rates in several advanced countries such as the United States and the United Kingdom by raising perceived wealth and relaxing credit constraints; iii) population ageing that may have contributed to a decline in the saving rates of some advanced economies (Bernanke, 2005).

3. This mechanism was strengthened in so far as the corresponding income loss in oil-importing countries was considered as temporary.

4. Some authors have also pointed towards too lax monetary policy (in particular in the US) as a source for too low interest rates (e.g. Obstfeld, 2010; Obstfeld and Rogoff, 2009), though this view is heavily disputed (for example, Bernanke, 2010, concludes that there is little empirical support for this proposition). 
9. The economic crisis was accompanied by a substantial narrowing of global saving-investment gaps as well as by a change in their composition. As for saving, household saving rates in developed countries rose from their pre-crisis levels on account of tighter credit conditions, rising labour market uncertainty and efforts to make up for the sudden wealth losses. The increase in household saving was particularly large in several deficit countries such as the United States, the United Kingdom, and Spain. In most OECD countries, higher household saving was, however, more than offset by lower government saving, implying that changes in saving behaviour contributed to a narrowing of imbalances foremost in surplus countries. The latter also applies to oil-exporting countries, where the high saving rates dropped on account of collapsing oil prices, thus reducing current account surpluses. As for investment, total investment rates fell substantially in the majority of countries, driven by falling business investment and, at least in those countries that had experienced house price and construction booms in the run-up to the crisis, falling residential investment. By contrast, the total investment rate rose noticeably in China, owing largely to the sizeable policy stimulus, thereby reducing the current account surplus. As argued by OECD (2010a), the narrowing of global saving-investment gaps is unlikely to be permanent; as the recovery unfolds and output gaps close, saving-investment gaps are widening again.

\section{Structural policy reforms and current accounts: some theoretical links}

10. Any reform that influences aggregate saving or investment will likely also alter a country's current account position. This section discusses the broad channels through which structural policies could influence the saving and investment behaviour of firms and households (more specific discussion of each individual reform area is provided in Section 4 when presenting the results of the empirical analysis). Current account constellations are the outcome of a global general equilibrium and thus do not only depend on domestic economic conditions but also on the conditions abroad. For simplicity, the discussion below assumes that no reforms take place in the rest of the world or at least that any such reforms are smaller in the magnitude of their effects than those in the domestic economy. Moreover, the focus mainly is on structural policies that affect domestic settings rather than on policies that directly affect capital flows (e.g. corporate tax reforms, removal of restrictions on trade and foreign direct investment). Partly for this reason, the discussion abstracts from the fact that any change in the domestic saving-investment gap must be accompanied by a corresponding change in net capital inflows/outflows and thus a change in the savinginvestment gap in the rest of the world. ${ }^{5}$ The discussion below also abstracts from adjustment mechanisms that ensure that changes in the saving-investment balance are matched by corresponding changes in the current account balance, not least real exchange rate adjustments. ${ }^{6}$

\subsection{Theoretical linkages between structural reforms and saving}

11. Structural policy reforms may influence the saving behaviour of private agents through a variety of channels. In particular, to the extent that households attempt to smooth consumption over time, structural policies may influence private saving rates by changing income patterns over the lifecycle, the uncertainty of these income streams, or the real rate of interest. In turn, reforms may change income patterns by affecting either productivity growth (e.g. product market reforms) or the age-income profile (e.g. pension reforms):

- The productivity growth channel: Structural reforms that raise productivity may affect the overall private saving rate through both a composition effect and changes in the saving rates of individual households. The composition effect emerges because the income gain from higher productivity is likely to benefit workers more than retirees and the former tend to have a higher

5. Equilibrium may also be restored through changes in other macroeconomic variables and in particular in interest rates.

6. For example, a reform that boosts consumption would put upward pressure on the relative price of nontradables and thereby weaken the trade balance to a point where the current account balance equals the (new) saving-investment balance. 
propensity to save (Modigliani, 1966). ${ }^{7}$ Individual saving rates may also change as households smooth consumption over time (Friedman, 1957). The direction and size of the impact will depend on whether the change in permanent income reflects an increase in current or future income and on whether income changes temporarily or permanently (see Box 1 and Fournier and Koske, 2010, for a more thorough discussion). ${ }^{8}$ Structural reforms such as product or labour market deregulation or reforms that increase financial market efficiency are usually thought to be associated with a temporary rise in the growth rate of income and thus a permanent shift in its future level, which sets in some time after the reform is implemented. This should lead to a temporary fall in the household saving rate, which, if large enough, may dominate the composition effect and the aggregate saving rate may actually decline in the aftermath of a reform before rising again once the income effects of the reform set in.

- The age-income profile channel: Structural reforms can also affect individual households' saving rates by altering the lifecycle pattern of income streams. For example, a pension reform that unexpectedly reduces the benefit replacement rate should increase the saving rates of the working-age population as households attempt to accumulate more wealth in order to offset the effect of lower future pensions on consumption in retirement. ${ }^{9}$ By contrast, unexpected increases in the statutory retirement age should reduce the saving rates of workers as they have more years to accumulate wealth and fewer years during which to spend this wealth. ${ }^{10}$ At an aggregate level the saving impact of pension reforms would be expected to show up only temporarily, as in the long run, the amount saved during the working period should broadly match the amount spent during retirement, in line with unchanged individual preferences. ${ }^{11}$

- The uncertainty channel: Households hold a certain amount of precautionary wealth as a cushion against unexpected adverse events such as unemployment, sickness or disability. This amount of precautionary wealth, and with it the level of precautionary saving, depends on the risk aversion of the household, the probability of adverse events and their expected severity. While policy is unlikely to affect the risk aversion of households, it may well affect the other two factors. For example, a lowering of employment protection has an ambiguous effect on the saving rate, since the higher likelihood of dismissal should increase precautionary saving, while the higher labour turnover should lower it by reducing the expected length of unemployment spells. Reforms that alter the sectoral specialization of economies may also influence precautionary saving by changing the volatility of GDP growth (a lowering of product market regulation in services sectors may raise their share of output which may in turn lower overall output volatility and precautionary saving).

7. In countries where private pensions are dominant, retirees might also gain from increased profits.

8. If a distinction is made between tradable and non-tradable goods, the saving impact of an income shock will also depend on whether consumers are more concerned about keeping overall consumption stable over time or keeping the composition of the consumption basket stable and on the sector in which the shock occurs since disturbances that affect the relative price structure over time also affect the optimal path of consumption and external borrowing (Dornbusch, 1983 and Fournier and Koske, 2010).

9. Aglietta et al. (2007) provide simulations of the impact of different pension reforms on aggregate saving in an overlapping-generations model.

10. This holds insofar as the effective retirement age also rises, as has typically been the case in the aftermath of past increases in the statutory retirement age across OECD countries (see, e.g. Duval, 2003). However, if the effective retirement age increases by less than the statutory age and individuals self-finance retirement ahead of the statutory age in order to stick with their original retirement plans, the saving rate might temporarily increase following the reform.

11. Although individuals may leave some of their wealth to their heirs, the size of the bequest should not rise indefinitely over generations. 
- The interest rate channel: Structural reforms may also affect the saving behaviour of households through changes in the real rate of interest that they face. For example, a strengthening of competition in the banking sector should reduce the spread between borrowing and lending rates by squeezing the profit margins of banks (and reduce the shadow real borrowing rate even more by relaxing quantitative constraints). Likewise, tax reforms should affect the saving decisions of firms and households through their impact on the after-tax rate of return on saving and interest expenses on loans. The ultimate impact on the saving rate is ambiguous, however, and depends on the relative sizes of the substitution, income and wealth effects (with the latter depending again on whether households are net lenders or net borrowers).

\section{Box 1. The theoretical impact of productivity shocks on saving and the current account ${ }^{1}$}

Structural reforms such as product or financial market deregulation typically lead to a gradual, but ultimately permanent, rise in the level of productivity. The size and even the sign of the associated impact on the saving behaviour of private agents, and thereby on a country's current account position, are theoretically ambiguous and depend on many factors. These include in particular consumers' preferences for consumption smoothing, their beliefs in whether the rise in the level of productivity is permanent or temporary, and the productivity effects of the reforms in tradable versus non-tradable sectors. To illustrate these channels, a number of productivity shocks have been simulated in a simple two-country DSGE model that distinguishes between tradable and non-tradable goods. For simplicity, the model features flexible prices and abstracts from capital accumulation, thereby focusing solely on the links between productivity and saving. Consumers live infinitely and have perfect foresight, so that they anticipate the consequences of a shock and adjust their consumption and labour supply accordingly. Also, the issue of precautionary saving behaviour is not dealt with in the model. The following main conclusions emerge from the analysis:

- The immediate current account impact of a gradual and ultimately permanent rise - and correctly interpreted as such by households - in overall productivity hinges crucially on whether consumers are more concerned about inter-temporal consumption smoothing (i.e. keeping overall consumption stable over time) or intra-temporal consumption smoothing (i.e. keeping the composition of the consumption basket stable). If households have a high propensity to smooth consumption over time, a reform that boosts aggregate productivity will be associated with a weakening of the current account position in the short run as consumers try to benefit from the future rise in income to consume more already today. This temporary deterioration in the current account is then gradually reversed as productivity rises towards its new level. By contrast, the current account may strengthen in the immediate aftermath of a reform if consumers have a low propensity for inter-temporal consumption smoothing, because households postpone their consumption increase to benefit from lower prices in the future as productivity rises (all else equal, the fall in prices leads to a higher real rate of interest; see also Dornbusch, 1983).

- Reforms that boost productivity solely in the tradable goods sector unambiguously lead to a weakening of the current account in the short run, which is gradually reversed once the productivity increase sets in. The short-run current account reaction is driven by two factors: First, consumers try to benefit from the future rise in income by consuming more already today and second, they frontload consumption since the relative price of non-tradable goods is seen as rising over time. Since both effects work in the same direction the magnitude of the current account reaction is larger than in the case of an economy wide shock (where the second effect partially offsets the first or even outweighs it if consumers have a low propensity to smooth consumption over time). For structural reforms that boost productivity only in the nontradable goods sector, the direction of the short-run current account reaction is ambiguous and depends on consumers' preferences for intra-temporal vs. inter-temporal consumption smoothing, similarly to the consequences of an economy-wide shock.

- If a reform boosts the level of productivity only temporarily - or if economic agents perceive the impact of the reform as such - and consumers have a strong preference for consumption smoothing, the current account temporarily strengthens as households save part of the higher income for the future: they foresee a decrease of income and save accordingly.

1. This box is based on Fournier and Koske (2010), "A Simple Model of the Relationship between Productivity, Saving and the Current Account", OECD Economics Department Working Paper No. 816. 


\subsection{Theoretical linkages between structural reforms and investment}

12. Since firms weigh the returns on an investment project against its cost when making their investment decisions (Jorgenson, 1963; Hall and Jorgenson, 1967), structural reforms can influence the investment rate by altering the cost of the investment good, the revenue that the investment will generate and/or the uncertainty of that revenue stream:

- The cost channel: Structural reforms that reduce the cost of an investment project - e.g. by lowering the price of investment goods or the cost of financial capital - should increase the investment rate by raising the profitability of marginal investment projects. Examples include financial reforms that reduce lending margins, tax reforms that increase depreciation allowances, or the relaxation of competition-unfriendly regulation in capital goods sectors that lowers the price of investment goods. ${ }^{12}$

- The revenue channel: Reforms that boost the expected revenues from investment projects stimulate investment. Therefore, reforms that boost total factor productivity (TFP) growth on a long-lasting basis (e.g. improvements in innovation frameworks that address innovation failures and durably raise overall $\mathrm{R} \& \mathrm{D}$ spending) or temporarily (e.g. efficiency-enhancing tax reforms) should have permanent and temporary positive effects on overall investment, respectively. ${ }^{13}$ While product market deregulation should push up the investment rate through temporarily higher TFP growth, this effect may be counteracted, at least in the short run, by the reduction in rates of return on capital for incumbent firms associated with the squeeze in profit margins (Alesina et al., 2005).

- The uncertainty channel: Relaxing the assumption of certainty that underpins the cost of capital theory, structural reforms may also influence the investment rate by altering the level of uncertainty in a context where investment is at least partly irreversible (Abel and Eberly, 1994) ${ }^{14}$ In this sense reforms that reduce uncertainty (e.g. by broadening prudential regulation or by strengthening property rights) should raise the investment rate.

\section{3. $\quad$ Further channels of influence of structural reforms}

13. A number of additional channels may shape the impact of structural reforms on saving, investment and current accounts:

- Expectations of future structural policy settings: The magnitude and, potentially, the direction of the saving/investment response to a structural policy change may depend on the credibility of the reform. For example, while a productivity-enhancing reform would usually reduce the saving rate if the reform is considered as permanent, it could instead induce households to save

12. Ultimately, the investment decision of a firm should not depend on the absolute price of an investment good but on its relative price vis-à-vis alternative factors for production. In this sense, reforms that affect the price of labour or other inputs should also influence the investment rate, with the size and the direction of the impact depending on the rate of substitution between production factors. For example, Alesina et al. (2002) show that higher government spending on wages has a sizable negative impact on private investment and attribute this result to wage spillovers between the public and private sectors.

13. The productivity-induced rise in profits may at least partially be offset by higher real interest rates or by declining world market prices - as has happened in the 1990s and 2000s in some countries that enjoyed large productivity gains in the production of ICT goods.

14. Higher uncertainty can be thought of as raising the magnitude by which the return on investment must exceed its cost (Dixit and Pindyck, 1994) or by directly raising costs (Abel and Eberly, 1994). 
more if they expect the reform to be fully taken back in the future (see the discussion in Box 1). By the same token, firms and households might change their behaviour even in the absence of a reform if they believe that the status quo cannot be maintained. For example, if households believe that the national pension system is unsustainable, they might increase their saving even before the government actually decides to undertake reforms that cut into pension wealth. Moreover, uncertainty about a structural reform should boost saving and lower investment through the uncertainty channel discussed above.

- Financial market imperfections and the interdependence between saving and investment decisions: In imperfect financial markets, the saving and investment decisions of households and firms may not be independent from each other. For example, if information asymmetries drive a wedge between the internal and external cost of finance, companies might be reluctant to pay out dividends and instead use the funds to finance investment projects. ${ }^{15}$ Similarly, households are likely to accumulate a certain amount of wealth before purchasing property. Consequently, policies that influence the investment decisions of economic agents are likely to also alter their saving decisions, with ambiguous effects on the current account position. Similarly, international financial market imperfections and/or home bias in consumption may reduce the mobility of capital across countries, thereby causing aggregate saving and investment rates to be correlated, the so-called Feldstein-Horioka puzzle. Policy settings such as financial market regulation (e.g. barriers to entry in the banking sector, or macro-prudential regulatory settings such as maximum housing loan-to-value ratios) may impact the degree of interdependence between saving and investment decisions.

- The speed of shock transmission: The influence of structural policy changes on saving, investment and current accounts might be mediated by certain factors. In particular, the exchange rate regime may affect the speed at which actual saving and investment adjust to this new equilibrium - though it is unlikely to affect this new equilibrium itself - following a reform. Under a fixed exchange rate regime and sticky prices, the lack of an external adjustment mechanism should slow down adjustment, implying more persistent real exchange rate and current account disequilibria. ${ }^{16}$ Similarly, structural policies themselves may influence the speed of shock transmission. For example, a reduction in regulatory burdens may enhance the ability of firms to adjust their capital stock to productivity shocks, and thus the speed at which investment reacts to such shocks.

- Interactions between policies and between policies and macroeconomic conditions: Structural policies may interact with other policies or with macroeconomic conditions to influence the saving and investment behaviour of firms and households. For example, the impact of lower employment protection on the precautionary saving behaviour of households might be smaller where high unemployment benefits already provide some insurance against the risk of job loss. Likewise, wealth effects on saving could be larger in countries with more developed financial markets (Boone et al., 2001). Also, housing policy reforms such as removing land-use restrictions, raising taxes on vacant undeveloped lands, or relaxing competition-unfriendly regulation in the construction industry may amplify the reaction of housing investment to changes in demand (OECD, 2010b).

15. This may have been one reason why the surge in corporate profits in China over the past decade translated in an increase in retained earnings rather than in higher dividend payouts (e.g. Jha et al., 2009). It may also explain why companies in advanced economies increased net savings during the recent crisis.

16. This may partially explain for instance the persistent and sizeable imbalances within the euro area. 


\section{Empirical analysis of the effect of structural policies on saving, investment and current accounts}

\subsection{The empirical set-up}

14. Given the theoretical complexities and ambiguities discussed in the previous section, the impact of structural reforms on saving, investment and current accounts ultimately remains an empirical issue. It is explored here by estimating a series of reduced-form equations that relate the GDP shares of respectively saving, investment and the current account balance to policy indicators and a set of control variables. The policy indicators span five different policy areas: social welfare systems, regulation in labour, product and financial markets, and taxation (see Tables A1.1 and A1.2 in Annex 1 for a list of the policy indicators used and details on data sources and construction and Table A1.3 for some descriptive statistics). ${ }^{17}$ Taking a macroeconomic perspective allows examining a large set of countries simultaneously and exploiting a broad range of reform experiences. However, the discussion of the empirical results and their implications will also draw on recent microeconomic evidence on the link between structural policies and saving and investment, which tends to be narrower in scope but more robust to variations in, for example, the samples or the econometric methods than macroeconomic cross-country time-series analysis. The empirical analysis consists of two main parts:

- Cross-country/time-series regressions in the form of error correction models (ECMs) for an unbalanced panel data set covering 30 OECD countries. ${ }^{18,19}$ As it is likely that structural policy reforms have a different impact on public and private saving and investment - with some reforms likely to have virtually no impact on public saving/investment - the error correction models are estimated for both total and private saving and investment. Baseline equations are first estimated that only feature the control variables as explanatory factors, and in a second step, the policy indicators are introduced separately in the baseline specification. Some of the policy variables are also interacted with the error correction parameter to investigate whether structural reforms affect the speed of adjustment to long-term equilibrium, and with some of the control or other policy variables to test for policy interactions (see Box 2 for details on the specifications). As this analysis did not provide strong evidence of such interaction effects, the discussion below only briefly touches upon these results.

- Cross-section and cross-country/time-series regressions for a total of 117 OECD and nonOECD economies over the period 1993 to $2008 .^{20}$ While this second dataset is more limited in its time dimension and in the range of policies, it allows studying a broader set of countries and also facilitates the analysis of policies with little time variation. In a first step, baseline equations are estimated that relate the GDP shares of saving, investment and current account

17. The impact of indicators of overall institutional quality is not addressed in the analysis since a recent OECD study could not find any significant effect of this factor on saving and investment rates (Cheung et al., 2010).

18. All OECD member countries apart from Chile, Israel and Slovenia. The time dimension of the sample varies by country and by specification with the maximum time period covered being 1965 to 2008 .

19. By using an error correction specification the response of the dependent variable to a change in one of the explanatory variables may be stronger in the short run than in the long run and also differ in its sign (which could, for example, be relevant in the case of productivity shocks as discussed in Fournier and Koske, 2010).

20. The statistical data for Israel are supplied by and under the responsibility of the relevant Israeli authorities. The use of such data by the OECD is without prejudice to the status of the Golan Heights, East Jerusalem and Israeli settlements in the West Bank under the terms of international law. 
balances to a set of macroeconomic control variables, and in a second step these baseline equations are augmented by structural policy indicators (see Box 2 for details). ${ }^{21}$ To look beyond short-term fluctuations and limit the possibility of measurement error the regressions are carried out on non-overlapping five-year averages of the data. ${ }^{22}$ For some of the policy variables data are only available for a single five year time window (or even for just a single year), in which case the analysis is reduced to a pure cross-section regression.

\section{Box 2. Details on the empirical set-up}

The baseline dynamic panel regressions for the OECD sample take the following general form:

$$
\Delta Y_{i t}=\alpha\left(Y_{i t-1}-\delta_{i}-\lambda_{t}-\tau_{i} t-\beta X_{i t-1}\right)+\sum_{j=1}^{3} \Phi_{j} \Delta Y_{i t-j}+\sum_{j=0}^{3} \mathrm{~B}_{j} \Delta X_{i t-j}+\varepsilon_{i t}
$$

where the dependent variable $Y$ is alternatively the saving or investment to GDP ratio for the overall economy (public plus private) or the private sector, or the current account balance as a share of GDP. $X$ is a vector of control variables, $\varepsilon$ is an error term, and the indices $i$ and $t$ denote country and year. ${ }^{1}$ Insignificant short-run dynamic terms are dropped from the specification to obtain a parsimonious model. ${ }^{2}$ Equation (1) is estimated using the ordinary least squares estimator with standard errors that are robust to contemporaneous correlation and heteroskedasticity. ${ }^{3}$ All variables included in the ECMs are either stationary around a constant mean or trendstationary (Table A1.4 in Annex 1). In the current account equations, all explanatory variables are converted into deviations from a GDP-weighted cross-country average to emphasize that current accounts are influenced both by domestic and foreign economic conditions. The average is calculated across all countries for which data are available for a given year. ${ }^{4}$ The saving and investment equations, by contrast, feature the absolute values of all explanatory variables.

Since the results may be sensitive to the choice of deterministic regressors, all specifications are estimated including: i) only country fixed effects (to control for unobserved cross-country heterogeneity such as differences in institutions, non-economic factors and differences in national accounting rules); ii) country and period fixed effects (the latter controlling for unobserved shocks that affect all countries simultaneously); and iii) country fixed effects and country-specific time trends (the latter capturing e.g. policy reforms or trending macroeconomic variables such as inflation). ${ }^{6}$ While the inclusion of these deterministic regressors increases the number of coefficients to be estimated, thus rendering the model less parsimonious, not controlling for them could potentially lead to a sizeable omitted variable bias. Furthermore, standard tests for the significance of the deterministic regressors generally reject the hypothesis that they are jointly equal to zero across countries. The discussion of the results mainly focuses on the specifications that feature both country and period fixed effects. While the results for specifications with country fixed effects only are very similar and therefore not shown in the paper, the results for the specifications with country fixed effects and country-specific time trends are shown in Annex 1.

Three different analyses are carried out to investigate the impact of structural policies on saving, investment, and the current account. The first analysis investigates whether structural policies have an impact on top of any impact that works through changes in the macroeconomic variables that are already included in the baselines. This is done by including the structural policy indicators as separate explanatory variables both in the short run and in the long run of the baseline specification (1):

$$
\Delta Y_{i t}=\alpha\left(Y_{i t-1}-\delta_{i}-\lambda_{t}-\tau_{i} t-\beta X_{i t-1}-\gamma P_{i t-1}\right)+\sum_{j=1}^{3} \Phi_{j} \Delta Y_{i t-j}+\sum_{j=0}^{3} \mathrm{~B}_{j} \Delta X_{i t-j}+\sum_{j=0}^{3} \Gamma_{j} \Delta P_{i t-j}+\varepsilon_{i t}
$$

where $P$ is a policy indicator. ${ }^{8}$ The policy indicators are introduced one-by-one into the baseline specification and also simultaneously (taking a single indicator from each policy area). While the latter approach has the advantage of reducing the risk of omitted variable bias, it reduces the size of the sample. Introducing indicators from different policy areas simultaneously does in general not affect the conclusions compared with a one-by-one approach. Sensitivity analysis is carried out to verify whether the results are robust to sample variations, namely to:

21. For this broader country set no data on private saving and investment rates are available.

22. For all macroeconomic control variables, a five year average is calculated whenever data are available for at least three years; otherwise, the data point is reported as missing. For policy variables, an average is calculated whenever data are available for at least one year. For some of the policy variables data are only available for a single five-year time window (or even just a single year), in which case the analysis is reduced to a pure cross-section regression. 
i) exclusion of influential data points; and ii) exclusion of individual countries from the sample (see Annex 1).

Some of the policy variables change only slowly over time, in which case a fixed effects estimation of equation (2) is likely to produce inaccurate point estimates (Beck, 2001; Beck and Katz 2001). To circumvent this problem while keeping the fixed effects approach, a special estimator is applied that essentially relies on a random effects model for the almost-time-invariant explanatory variables and a fixed-effects model for the remaining ones (further details on this estimator can be found in Annex 2). This estimator is used for all policy variables, for which the share of the cross-country variance in the total variance exceeds $75 \%$, a threshold inspired by the rules of thumb of Plümper and Troeger (2007). These are employment protection legislation (and its sub-components), public social spending (total, old-age and health) and the statutory retirement age (Table A1.3 in Annex 1). In practice, however, the use of the special estimator is not found to influence the results obtained for these policies. ${ }^{9}$

The second type of analysis explores whether structural policies have an impact on the speed of adjustment to long-term equilibrium. For example, by reducing capital stock adjustment costs, product market deregulation could speed up the adjustment of the investment-to-GDP ratio to its new equilibrium level following an exogenous shock (Alesina et al., 2005). This is done by interacting the error correction parameter $\alpha$ with a policy indicator $P$ (measured as deviation from the sample average to facilitate interpretation):

(3) $\Delta Y_{i t}=-\left(\alpha+\varphi\left(P_{i t}-\overline{\bar{P}}\right)\right)\left(Y_{i t-1}-\delta_{i}-\lambda_{t}-\tau_{i} t-\beta X_{i t-1}\right)+\sum_{j=1}^{3} \Phi_{j} \Delta Y_{i t-j}+\sum_{j=0}^{3} \mathrm{~B}_{j} \Delta X_{i t-j}+\varepsilon_{i t}$

A positive (negative) sign of $\varphi$ means that a higher value/score on a certain policy indicator is associated with a faster (slower) convergence to the new equilibrium. Specification (3) relies on the long run of the baseline specification and thus ignores any permanent effects of policies on saving and investment rates.

The third type of analysis explores the extent to which interactions across different policies, as well as across policies and macroeconomic conditions, matter. For example, the link between employment protection and precautionary saving may be expected to vary depending on the generosity of unemployment benefits. To this end, specification (2) which estimates only average effects of policies is extended to allow for interactions between two different policy indicators $P^{1}$ and $P^{2}$ (specification (4)) or between a policy indicator $P^{1}$ and a macroeconomic variable $X^{1}$ (specification (5)). Following standard practice, the interactions are specified as multiplicative terms, which take the form of products of deviations of policies and macroeconomic variables from their sample means:

$$
\begin{aligned}
& \Delta Y_{i t}=\alpha\left(Y_{i t-1}-\delta_{i}-\lambda_{t}-\tau_{i} t-\beta X_{i t-1}-\gamma P_{i t-1}^{1}-\mu P_{i t-1}^{2}-\tau\left(P_{i t-1}^{1}-\bar{P}^{1}\right)\left(P_{i t-1}^{2}-\overline{\bar{P}}^{2}\right)\right) \\
& \quad+\sum_{j=1}^{3} \Phi_{j} \Delta Y_{i t-j}+\sum_{j=0}^{3} \mathrm{~B}_{j} \Delta X_{i t-j}+\sum_{j=0}^{3} \Gamma_{j} \Delta P_{i t-j}^{1}+\sum_{j=0}^{3} \Omega_{j} \Delta P_{i t-j}^{2}+\sum_{j=0}^{3} \mathrm{~T}_{j} \Delta\left(\left(P_{i t-j}^{1}-\overline{\bar{P}}^{1}\right)\left(P_{i t-j}^{2}-\overline{\bar{P}}^{2}\right)\right)+\varepsilon_{i t} \\
& \Delta Y_{i t}=\alpha\left(Y_{i t-1}-\delta_{i}-\lambda_{t}-\tau_{i} t-\beta X_{i t-1}-\gamma P_{i t-1}^{1}-\tau\left(X_{i t-1}^{1}-\overline{\bar{X}}^{1}\right)\left(P_{i t-1}^{1}-\overline{\bar{P}}^{1}\right)\right) \\
& \quad+\sum_{j=1}^{3} \Phi_{j} \Delta Y_{i t-j}+\sum_{j=0}^{3} \mathrm{~B}_{j} \Delta X_{i t-j}+\sum_{j=0}^{3} \Gamma_{j} \Delta P_{i t-j}^{1}+\sum_{j=0}^{3} \mathrm{~T}_{j} \Delta\left(\left(X_{i t-j}^{1}-\overline{\bar{X}}^{1}\right)\left(P_{i t-j}^{1}-\overline{\bar{P}}^{1}\right)\right)+\varepsilon_{i t}
\end{aligned}
$$

where $\overline{\bar{P}}^{1}, \overline{\bar{P}}^{2}$ and $\overline{\bar{X}}^{1}$ are the sample means (across countries and over time) of $P^{1}, P^{2}$ and $X^{1}$, respectively, and other variables are denoted as before.

The analysis that involves the broader country set of both OECD and non-OECD economies is based on the following equation:

$$
\tilde{Y}_{i t}=\alpha+\beta \tilde{X}_{i t}+\gamma \tilde{P}_{i t}+\varepsilon_{i t}
$$

where a tilde denotes a five-year average and all other notations are as before. The equation is estimated with linear least squares, using a variance-covariance matrix that is robust to country-specific heteroskedasticity. In a first step, equation (6) is estimated relating the GDP shares of saving, investment and current account balances only to macroeconomic control variables. In a second step, structural policy indicators are introduced one-by-one into these baseline specifications. The broader dataset is also used to test for policy interactions:

$$
\tilde{Y}_{i t}=\alpha+\beta \tilde{X}_{i t}+\gamma \tilde{P}_{i t}^{1}+\varpi \tilde{P}_{i t}^{2}+\kappa\left(\tilde{P}_{i t}^{1}-\overline{\overline{\widetilde{P}}}^{1}\right)\left(\tilde{P}_{i t}^{2}-\overline{\overline{\widetilde{P}}}^{2}\right)+\varepsilon_{i t}
$$

where $\overline{\overline{\widetilde{P}}}$ and $\overline{\overline{\widetilde{P}}}^{2}$ are the sample means (across countries and over time) of respectively $\tilde{P}^{1}$ and $\tilde{P}^{2}$.

The empirical strategy has a number of shortcomings which have to be kept in mind when interpreting the 
results. First, the approach does not explicitly account for the joint determination of current accounts and some of the explanatory variables (e.g. interest rates), potentially leading to an endogeneity bias. Second, it does not allow distinguishing between different types of shocks (e.g. temporary versus permanent shocks, expected versus unexpected shocks, credible versus non-credible shocks). The analysis is thus likely to capture an average effect across heterogeneous reform experiences, which reduces chances of obtaining significant and robust results. ${ }^{10}$ Third, the approach treats saving and investment decisions separately. As discussed in the previous section this assumption of independence between saving and investment is unlikely to be fulfilled, especially during earlier periods of the sample when the Feldstein-Horioka puzzle was still strong. Fourth, structural policies are likely to influence saving and investment decisions through changes in the macroeconomic control variables, reducing the chances of finding significant coefficients on the policy variables themselves. ${ }^{11}$

1. It might be more natural to think of equation (1) in terms of an autoregressive distributed lag (ARDL) model linking the (stationary) level of $Y$ to its lags as well as to current and lagged levels of $X$ and $P$. The ECM is strictly equivalent to an ARDL model, but gives direct estimates of the longer-run effects - i.e. cumulated over years - of the explanatory variables.

2. Lag delegation is done by successively dropping the least significant variable until all coefficients have an individual $p$ value below $10 \%$. Note that once some lags are dropped from the dynamic part of the ECM, it is no longer necessarily equivalent to an unrestricted autoregressive distributed lag (ARDL) model.

3. Controlling for autocorrelation is less relevant in the context of an ECM due to the inclusion of lagged dependent variables. Lagrange multiplier tests indeed indicate that the residuals do not suffer from autocorrelation. Alternative variancecovariance matrices that are robust to arbitrary heteroskedasticity and within-country serial correlation or country-specific heteroskedasticity (but not to correlation between residuals for different countries) produce very similar conclusions.

4. The maximum set of countries includes Australia, Austria, Belgium, Brazil, Canada, Chile, China, Czech Republic, Denmark, Estonia, Finland, France, Germany, Greece, Hungary, Iceland, India, Indonesia, Ireland, Israel, Italy, Japan, Korea, Luxembourg, Mexico, Netherlands, New Zealand, Norway, Poland, Portugal, Russia, Slovakia, Slovenia, South Africa, Spain, Sweden, Switzerland, Turkey, the United Kingdom, and the United States. While in principle calculating the average across all countries for which data are available might cause sudden jumps in the data in years where a large country is added to the list, calculating the average alternatively over the G7 economies and only for years for which data are available for all of them is found to hardly affect the results.

5. Measuring all variables relative to a world average as in the current account equations (not shown in the paper) produces very similar results.

6. While dynamic panel regressions with fixed effects may produce biased results when the time dimension of the panel $T$ is small and the number of cross sections $N$ is large (e.g. Nickell, 1981), the average $T$ in the regressions is generally large enough for the bias to be sufficiently small to be ignored.

7. In order not to increase the number of regressors and reduce degrees of freedom too much, linear time trends, period fixed effects and country fixed effects are not considered all together in a single specification.

8. For all policy variables that capture social welfare no short-run dynamics are included in the specification since some years of data had to be interpolated for these variables.

9. No lagged differences are included for these variables in the regressions since they show little dynamics over time.

10. In cases where the direction of impact differs across different types of shocks, the sign of the estimated coefficient may still give some hints on how economic agents perceived the shock, however.

11. A two-stage approach which would properly address the problem by first estimating the impact of structural policies on the macroeconomic variables and then incorporating the results in the saving, investment and current account equations is beyond the scope of this paper.

\subsection{The impact of macroeconomic conditions}

Saving

15. The baseline saving equations feature the real interest rate, the growth rates of productivity (measured as real GDP per worker) and the terms of trade, the youth and old-age dependency ratios and the government budget balance (Table 1). ${ }^{23,24}$ The results for the OECD sample are fairly robust to alternative specifications (see Tables A1.5 an A1.6 in Annex 1). ${ }^{25}$ The positive impact of productivity growth on

23. The budget balance is excluded from the static regressions that involve non-OECD countries as data for this variable are available only for a very small number of non-OECD countries.

24. Other variables that were initially included in the baseline regressions for the OECD sample but later dropped due to insignificance or lack of robustness include the GDP shares of the capital stock and the net foreign asset position, inflation, inflation volatility, GDP growth volatility, and the unemployment rate.

25. The main exceptions are the youth dependency ratio and the real interest rate which are neither significant for total nor for private saving in a pure - but arguably inappropriate - country fixed-effects regression that neither controls for common shocks nor for country-specific time trends. Moreover, the coefficient on the 
saving in the medium to long run is consistent with a standard life cycle framework: to the extent that higher productivity growth benefits workers more than retirees and saving rates per age remain unchanged, the higher saving rate of workers generates an increase in the aggregate saving rate. The positive relationship between improvements in the terms-of-trade and the aggregate saving rate can be explained by households smoothing consumption in the face of a transitory level shock. ${ }^{26}$ The effect appears to be stronger for oil exporting countries (see Table A1.7 in Annex 1), which is not surprising given that the terms of trade of these countries are highly influenced by the price of a finite resource. The short-run dynamics do not provide any evidence of overshooting with the transition of saving rates to the new equilibrium following a shock to the growth rates of productivity or the terms of trade being rather smooth. The regressions for the broader data set confirm the positive relationship between total saving rates and changes in productivity and the terms of trade, with the magnitudes of the estimated effects being very close to the medium to long-run effects found in the dynamic panel regressions for OECD countries (Table 2).

16. The old-age dependency ratio turns out to be negatively related to the aggregate saving rate in the medium to long run, in line with the standard life-cycle hypothesis that older people tend to have a higher propensity to consume out of income than people in their working age (Modigliani and Ando, 1963). The point estimate implies that a 1 percentage point increase in the old-age dependency ratio reduces total saving by about half a percentage point of GDP in the medium to long run, which is in line with the findings of other recent studies (e.g. Cheung et al., 2010) and with the estimate obtained in the regression for OECD and non-OECD countries. ${ }^{27,28}$ While the baseline specifications shown in Table 1 suggest that a rise in the youth dependency ratio temporarily reduces saving rates in OECD countries but leads to an increase in saving rates in the medium to long run, this result appears to be sensitive to the choice of deterministic control variables (i.e. country and period fixed effects, only country fixed effects or country fixed effects and country-specific time trends). ${ }^{29}$ Improvements in government budget balances have a significantly positive effect on total saving in the medium to long run, but reduce household saving, potentially due to (partial) Ricardian equivalence. ${ }^{30}$ The private saving offset is estimated at around twothirds, which is somewhat larger than the magnitudes found in previous studies (e.g. Cheung et al., 2010; Röhn, 2010). Changes in the real interest rate also have a significant influence on saving behaviour, with a 1 percentage point increase in the real interest rate lowering private saving by about half a percentage point

youth dependency ratio changes its sign when including country-specific time trends instead of period fixed effects.

26. An improvement in a country's terms of trade increases real income, measured as the purchasing power of its exports, therefore affecting private saving in the same way as income growth (e.g. Ostry and Reinhart, 1991). The finding of a significantly positive relationship with the terms of trade is in line with other macroeconomic studies on the determinants of saving (e.g. Ferrucci and Miralles, 2007; de Mello et al., 2004; de Serres and Pelgrin, 2003; Loayza et al., 2000).

27. While the expected longer longevity which is typically associated with a rise in the old-age dependency ratio and which may encourage younger people to increase their saving rate may counteract the effect of a higher share of dis-savers, the latter effect apparently dominates.

28. The medium to long-run elasticities obtained from the regressions for OECD countries and the elasticity obtained from the regression for OECD and non-OECD countries are very close to those reported, for example, by Cheung et al. (2010) and Furceri and Mourougane (2010).

29. While the negative short-run effect is consistent with the typical humped-shaped saving rate profile across age cohorts, the positive medium- to long-run effect could be explained by medium-aged households increasing their saving rate in response to a rise in the youth dependency ratio to prepare for future education expenses.

30. The results should be interpreted with care, however, since the specifications do not control for possible reverse causality between government budget balances and saving rates. 
of GDP. ${ }^{31}$ One interpretation is that, on average across countries, the income effect of an interest rate change outweighs its substitution and wealth effects.

17. Figure A1.1 in Annex 1 show the in-sample and out-of-sample fit of the estimated baseline saving equations for selected OECD countries. While fitted saving rates track actual rates fairly well for most countries in-sample, this is clearly driven by the lagged dependent variables for at least some of them. To explore the out-of-sample forecasting properties of the equations, they are estimated until 2000 and then used to dynamically forecast the GDP shares of saving and investment until 2008. Since the period fixed effects do not exhibit any clear trend, they are set equal to zero over the forecasting horizon. The outof-sample fit varies considerably across countries, though in general actual saving rates lie within the $90 \%$ confidence interval around the forecast. ${ }^{32}$ For example, while the equations track the actual saving rate fairly well for Japan, Germany, the United Kingdom, Australia and the Netherlands, they perform rather poorly for the United States, Spain and Norway. This rather poor forecasting performance for some countries could be explained by the omission from the baseline equations of structural policy variables which may explain at least some of the recent changes in saving rates. ${ }^{33}$

\section{Investment}

18. The baseline investment specifications feature the user cost of capital (or the real interest rate when based on the second sample that involves non-OECD countries), productivity growth and the growth rate of the working age population, and yield results that are qualitatively in line with existing empirical evidence. ${ }^{34}$ The regressions for the OECD sample indicate that higher TFP growth, a higher growth rate of the working age population or lower cost of capital raise investment rates in the medium to long run (Table 1). The user cost effect is consistent with the notion that higher user costs lower the returns on investment projects and confirms the findings of previous OECD work (e.g. Vartia, 2008; Schwellnus and Arnold, 2008). The point estimate implies that a 1 percentage point increase in the user cost of capital reduces private investment by a quarter of a percentage point of GDP in the medium to long-run, which is somewhat smaller than the magnitude implied by other studies (Cummins et al., 1994). As it turns out, a fall in the interest rate is found to raise saving by slightly more than investment. The short-run dynamics suggest that, following a shock to any of the three explanatory variables, half of the full adjustment of the private investment rate to the new equilibrium is achieved within four years. The results are very robust to alternative choices of deterministic regressors and to the omission of influential data points (see Tables A1.5 and A1.6 in Annex 1). ${ }^{35}$ Moreover, the conclusions are confirmed by the regressions for the broader

31. This elasticity is close to that obtained in previous OECD work (de Serres and Pelgrin, 2003; de Mello et al., 2004) and somewhat larger than that obtained here for the broader OECD/non-OECD sample.

32. The baseline specifications with country-specific time trends tend to produce somewhat better out-ofsample forecasts (results not shown).

33. Equations that feature policy variables yield indeed better out-of-sample forecasts for a number of countries, including in particular Spain and the United States.

34. A number of other variables were initially included in the dynamic panel baseline specifications but were later dropped because of insignificance. These are the GDP shares of the capital stock and the net foreign asset position and GDP growth volatility.

35. The results are also robust to a change in the precise calculation of the user cost variable. For example, when assuming a uniform depreciation rate of $11.8 \%$ (which corresponds to the sample mean) across countries and time, a 1 percentage point decline in the user cost of capital is estimated to raise total and private investment by respectively 0.26 and 0.20 percentage points of GDP. 
ECO/WKP(2010)71

Table 1. Baseline estimation results for OECD sample 1965-2008 - Country and period fixed effects

\begin{tabular}{|c|c|c|c|c|c|}
\hline & SAVT & SAVP & INVT & INVP & $\mathrm{CA}$ \\
\hline \multicolumn{6}{|l|}{ Long-run relationship } \\
\hline User cost of capital & & & $\begin{array}{l}-0.150^{* *} \\
(0.062)\end{array}$ & $\begin{array}{l}-0.249^{* * *} \\
(0.070)\end{array}$ & $\begin{array}{l}-0.113 \\
(0.157)\end{array}$ \\
\hline Productivity growth & $\begin{array}{l}1.063^{\star \star *} \\
(0.386)\end{array}$ & $\begin{array}{l}0.542^{\star *} \\
(0.250)\end{array}$ & $\begin{array}{l}1.908^{* * *} \\
(0.343)\end{array}$ & $\begin{array}{l}1.912^{\star \star \star} \\
(0.335)\end{array}$ & $\begin{array}{l}-1.497^{\star * *} \\
(0.530)\end{array}$ \\
\hline Change in population aged $15-64$ & & & $\begin{array}{l}1.938^{* * *} \\
(0.526)\end{array}$ & $\begin{array}{c}0.982^{* *} \\
(0.481)\end{array}$ & $\begin{array}{l}-4.550^{* * *} \\
(1.654)\end{array}$ \\
\hline Change in terms of trade & $\begin{array}{l}0.427^{\star * \star} \\
(0.130)\end{array}$ & $\begin{array}{c}0.172^{\star *} \\
(0.083)\end{array}$ & & & $\begin{array}{l}0.489^{* * *} \\
(0.162)\end{array}$ \\
\hline Real long-term interest rate & $\begin{array}{l}-0.623^{\star \star *} \\
(0.233)\end{array}$ & $\begin{array}{l}-0.486^{\star *} \\
(0.205)\end{array}$ & & & $\begin{array}{c}0.012 \\
(0.324)\end{array}$ \\
\hline Old-age dependency ratio & $\begin{array}{l}-0.547^{\star * \star} \\
(0.145)\end{array}$ & $\begin{array}{l}-0.330^{\star *} \\
(0.156)\end{array}$ & & & $\begin{array}{l}-0.680^{* * *} \\
(0.216)\end{array}$ \\
\hline Youth dependency ratio & $\begin{array}{l}0.294^{* *} \\
(0.146)\end{array}$ & $\begin{array}{l}0.432^{* * *} \\
(0.142)\end{array}$ & & & $\begin{array}{c}0.259^{*} \\
(0.141)\end{array}$ \\
\hline Government net lending & $\begin{array}{l}0.322^{* * *} \\
(0.118)\end{array}$ & $\begin{array}{l}-0.596^{* * *} \\
(0.107)\end{array}$ & & & $\begin{array}{c}0.008 \\
(0.160)\end{array}$ \\
\hline \multicolumn{6}{|l|}{ Short-run dynamics } \\
\hline Error correction parameter & $\begin{array}{l}-0.182^{* * *} \\
(0.038)\end{array}$ & $\begin{array}{l}-0.223^{* * *} \\
(0.037)\end{array}$ & $\begin{array}{l}-0.176^{\star * *} \\
(0.025)\end{array}$ & $\begin{array}{l}-0.178^{* * *} \\
(0.028)\end{array}$ & $\begin{array}{l}-0.210^{\text {*** }} \\
(0.038)\end{array}$ \\
\hline$\Sigma \Delta$ Dependent variable & $\begin{array}{l}-0.114^{\star \star \star} \\
(0.040)\end{array}$ & & $\begin{array}{l}0.154^{\star \star \star} \\
(0.057)\end{array}$ & $\begin{array}{l}0.152^{\star \star \star} \\
(0.058)\end{array}$ & \\
\hline$\Sigma \Delta$ User cost of capital & & & $\begin{array}{l}0.039^{* * *} \\
(0.013)\end{array}$ & $\begin{array}{l}-0.038^{* * *} \\
(0.011)\end{array}$ & \\
\hline$\Sigma \Delta$ Productivity growth & $\begin{array}{l}0.222^{\star * \star} \\
(0.055)\end{array}$ & $\begin{array}{c}0.042 \\
(0.079)\end{array}$ & $\begin{array}{l}0.207^{\star \star \star} \\
(0.034)\end{array}$ & $\begin{array}{l}0.253^{\star * *} \\
(0.030)\end{array}$ & $\begin{array}{l}-0.234^{\star *} \\
(0.096)\end{array}$ \\
\hline$\Sigma \Delta$ Change in population aged $15-64$ & & & $\begin{array}{l}0.422^{\star \star *} \\
(0.106)\end{array}$ & & $\begin{array}{l}-1.106^{\star * *} \\
(0.362)\end{array}$ \\
\hline$\Sigma \Delta$ Change in terms of trade & $\begin{array}{l}0.100^{* \star *} \\
(0.014)\end{array}$ & $\begin{array}{l}0.047^{\star \star \star} \\
(0.016)\end{array}$ & & & $\begin{array}{l}0.135^{\star * *} \\
(0.023)\end{array}$ \\
\hline$\Sigma \Delta$ Real long-term interest rate & $\begin{array}{l}-0.071^{* *} \\
(0.028)\end{array}$ & $\begin{array}{l}-0.049^{*} \\
(0.027)\end{array}$ & & & $\begin{array}{l}-0.143^{* * *} \\
(0.055)\end{array}$ \\
\hline$\Sigma \Delta$ Old-age dependency ratio & $\begin{array}{c}0.562^{* *} \\
(0.240)\end{array}$ & $\begin{array}{l}0.248^{* * *} \\
(0.365)\end{array}$ & & & \\
\hline$\Sigma \Delta$ Youth dependency ratio & $\begin{array}{l}-0.522^{\text {** }} \\
(0.146)\end{array}$ & $\begin{array}{l}-0.342^{*} \\
(0.179)\end{array}$ & & & $\begin{array}{l}-0.742^{* * *} \\
(0.276)\end{array}$ \\
\hline$\Sigma \Delta$ Government net lending & $\begin{array}{l}0.178^{\star * *} \\
(0.033)\end{array}$ & $\begin{array}{l}-0.416^{\star \star \star} \\
(0.042)\end{array}$ & & & $\begin{array}{c}0.114^{*} \\
(0.062)\end{array}$ \\
\hline
\end{tabular}

Note: Robust standard errors in parentheses. ${ }^{*},{ }^{* *}$ and ${ }^{* * *}$ denote significance at the $10 \%, 5 \%$ and $1 \%$ significance level. SAVT, SAVP, INVT, INVP, and CA denote the GDP shares of respectively total saving, private saving, total investment, private investment, and the current account balance. All models include country and period fixed effects. 
data set of OECD and non-OECD countries (Table 2). ${ }^{36}$ The out-of-sample forecasting performance of the estimated investment equations varies considerably across countries (Figure A1.2 in Annex 1). For example, the equations produce a very good forecast for the United States and, to a lesser extent, for the Netherlands. In the case of Germany, the United Kingdom and Norway, the equations perform well at least during more recent years, though they are not able to predict movements in the investment rate at the beginning of the forecasting period (i.e. in 2001/2002). ${ }^{37}$

\section{Current account}

19. The current account equations feature all macroeconomic variables that have a significant influence on total saving, total investment or both and yield results that are broadly consistent with the regression results for the two components. ${ }^{38}$ The regressions for OECD countries indicate that changes in productivity, changes in the size of the working age population, and changes in the terms of trade have a lasting impact on current account positions (Table 1). However, the current account equations do not provide any evidence that the real interest rate have a lasting impact on current account positions. The somewhat counter-intuitive relative magnitudes of the medium- to long-run interest rate elasticities found in the saving and investment rate equations do thus not carry over to the current account equation. As for the user cost of capital, the real interest rate and the dependency ratios, the results are sensitive to the precise specification used (see Tables A1.5 and A1.6 in Annex 1). Overall, the results are consistent with those from comparable studies (e.g. Chinn and Ito, 2007; Cheung et al., 2010). In the regression for OECD and non-OECD countries only the two dependency ratios and terms-of-trade changes come out as significant (Table 2).

Table 2. Baseline estimation results for OECD/non-OECD sample

\begin{tabular}{l|c|c|c}
\hline & SAVT & INVT & CA \\
\hline Real interest rate & $-0.101^{* * *}$ & $-0.069^{* *}$ & -0.059 \\
Productivity growth & $(0.031)$ & $(0.033)$ & $(0.046)$ \\
& $0.326^{*}$ & $1.146^{\star * *}$ & -1.011 \\
Change in population aged 15-64 & $(0.196)$ & $(0.308)$ & $(0.659)$ \\
& & $0.514^{*}$ & 0.454 \\
Change in terms of trade & & $(0.282)$ & $(0.924)$ \\
& $0.263^{* *}$ & & $0.501^{* * *}$ \\
Old-age dependency ratio & $(0.120)$ & & $(0.131)$ \\
Youth dependency ratio & $-0.572^{* * *}$ & & $-0.323^{*}$ \\
\hline Number of cross sections & $(0.139)$ & & $(0.175)$ \\
\hline Number of observations & $-0.281^{* * *}$ & & $-0.223^{\star * *}$ \\
\hline
\end{tabular}

Note: Robust standard errors in parentheses. *, ${ }^{* *}$ and ${ }^{* * *}$ denote significance at the $10 \%, 5 \%$ and $1 \%$ significance level. SAVT, INVT, and CA denote the GDP shares of respectively total saving, total investment, and the current account balance.

36. The real interest rate effect appears to be about five times larger for OECD than for non-OECD economies, whereas for the other explanatory variables, there is no evidence that elasticities differ between OECD and non-OECD countries.

37. Equations that feature policy variables yield better out-of-sample forecasts for several countries, including Japan, Germany and the United Kingdom, among others.

38. The set of explanatory variables does not feature the real exchange rate since it is jointly determined with the current account. 


\section{Implications for the impact of structural policies}

20. Insofar as structural policies affect the macroeconomic variables included in the baseline specifications, significant coefficients on these variables imply that these reforms should ultimately also affect saving and investment rates. In particular, there is growing evidence that removing anti-competitive product market regulation, relaxing overly stringent employment protection legislation and fostering the completeness and depth of financial markets all boost productivity growth. ${ }^{39}$ The empirical results in Tables 1 and 2 would therefore imply that such reforms also have a negative impact on the current account position. Similar implications can be derived from the significant influence of government fiscal balances on saving since structural reforms can, and often do have side-effect on public budgets. ${ }^{40}$

\subsection{The impact of social welfare reform}

21. The empirical analysis shows that a higher GDP share of public spending on health is associated with lower saving rates (Tables 3 and 4), in line with the notion that improvements in the coverage and/or quality of social welfare schemes reduce the need for precautionary saving. ${ }^{41}$ The effect appears to be especially strong under low initial levels of social spending (Table 5 and Figure 3, panel A), consistent with existing evidence (e.g. Furceri and Mourougane, 2010; Baldacci et al., 2010). The point estimates for the OECD sample imply that, on average, a 1 percentage point increase in the GDP share of public health spending reduces total and private saving rates by over $1 \frac{1}{2}$ percentage points in the medium to long run. The standard deviation around this point estimate is high, however. For other areas of social welfare, the analysis yields less robust results. The results depend in particular on the choice of deterministic control variables, with higher total public social spending, ${ }^{42}$ higher public social spending on old age ${ }^{43}$ and higher and more long-lasting unemployment benefits only found to reduce saving rates in specifications that feature country-specific time trends (see Table A1.8 in Annex 1). ${ }^{44}$ The current account regression results are in line with those obtained for saving, with more developed public health care systems being associated with weaker current account positions.

39. For product market regulation see, for example, Scarpetta and Tressel (2002), Nicoletti and Scarpetta (2003), Conway et al. (2006) and the literature review by Schiantarelli (2008); for employment protection legislation see, for example, Scarpetta and Tressel (2002; 2004) and Bassanini and Venn (2007); for financial market reform see, for example, de Serres et al. (2006) and the literature surveys by Levine (2005) and Papaioannou (2007); and for innovation policy, see Box (2009).

40. Though quantitatively of minor importance (especially in the short to medium run), it should be noted that structural policies may affect saving and investment also through the demographic variables. Examples include improvements in the availability of early childcare places (which might raise fertility) or improvements in health care provision (which might increase longevity).

41. The finding is robust to variations in the sample and in the precise specification (Tables A1.8 to A1.10 and Figures A1.3 and A1.4 in Annex 1).

42. Total public social spending includes, among others, public spending on old age, survivors, incapacityrelated benefits, health, family, active labour market programmes, unemployment, and housing.

43. Public social spending on old age includes, among others, spending on pensions and residential care/homehelp services.

44. Insofar as the social welfare reforms affect the level of employment (e.g. in the case of pension or unemployment benefit reform) they should also alter investment. However, this effect is likely to be of secondary importance, as also suggested by the current account regressions. 
$\mathrm{ECO} / \mathrm{WKP}(2010) 71$

Table 3. The impact of structural policies on saving, investment and current accounts in OECD countries

Baseline equations augmented with structural policy indicators

\begin{tabular}{|c|c|c|c|c|c|c|c|c|c|c|}
\hline & \multicolumn{2}{|c|}{ SAVT } & \multicolumn{2}{|c|}{ SAVP } & \multicolumn{2}{|c|}{ INVT } & \multicolumn{2}{|c|}{ INVP } & \multicolumn{2}{|c|}{$\mathrm{CA}$} \\
\hline & LR & SR & LR & SR & LR & SR & LR & SR & LR & SR \\
\hline \multicolumn{11}{|l|}{ Social security programs } \\
\hline $\begin{array}{l}\text { Unemployment benefit } \\
\text { replacement rate }\end{array}$ & $\begin{array}{c}0.008 \\
(0.067)\end{array}$ & & $\begin{array}{l}-0.029 \\
(0.052)\end{array}$ & & & & & & $\begin{array}{l}-0.090 \\
(0.088)\end{array}$ & \\
\hline $\begin{array}{l}\text { Public social spending, } \\
\text { total }\end{array}$ & $\begin{array}{l}-0.165 \\
(0.191)\end{array}$ & & $\begin{array}{l}-0.260 \\
(0.206)\end{array}$ & & & & & & $\begin{array}{l}-0.185 \\
(0.304)\end{array}$ & \\
\hline $\begin{array}{l}\text { Public social spending, old } \\
\text { age }\end{array}$ & $\begin{array}{c}0.099 \\
(0.564)\end{array}$ & & $\begin{array}{l}-0.005 \\
(0.499)\end{array}$ & & & & & & $\begin{array}{l}-0.008 \\
(0.518)\end{array}$ & \\
\hline $\begin{array}{l}\text { Public social spending, } \\
\text { health }\end{array}$ & $\begin{array}{l}-1.889^{* * *} \\
(0.612)\end{array}$ & & $\begin{array}{l}-1.549^{* * \star} \\
(0.523)\end{array}$ & & & & & & $\begin{array}{l}-2.269^{* * *} \\
(0.626)\end{array}$ & \\
\hline Standard retirement age & $\begin{array}{l}-0.516^{*} \\
(0.291) \\
\end{array}$ & & $\begin{array}{l}-0.664^{* *} \\
(0.283)\end{array}$ & & & & & & $\begin{array}{l}-0.351 \\
(0.396)\end{array}$ & \\
\hline \multicolumn{11}{|l|}{ Labour market policy } \\
\hline $\begin{array}{l}\text { Employment protection } \\
\text { legislation (EPL) }\end{array}$ & $\begin{array}{l}-0.456 \\
(0.576)\end{array}$ & & $\begin{array}{c}0.068 \\
(0.431)\end{array}$ & & $\begin{array}{l}1.043^{* *} \\
(0.439)\end{array}$ & & $\begin{array}{l}0.626^{*} \\
(0.346)\end{array}$ & & $\begin{array}{l}-1.711^{* *} \\
(0.948)\end{array}$ & \\
\hline EPL on regular contracts & $\begin{array}{c}0.170 \\
(0.943)\end{array}$ & & $\begin{array}{l}0.595 \\
(0.821)\end{array}$ & & $\begin{array}{c}0.262 \\
(0.695)\end{array}$ & & $\begin{array}{c}0.181 \\
(0.444)\end{array}$ & & $\begin{array}{l}-0.980 \\
(1.188)\end{array}$ & \\
\hline $\begin{array}{l}\text { EPL on temporary } \\
\text { contracts }\end{array}$ & $\begin{array}{l}-0.270 \\
(0.375) \\
\end{array}$ & & $\begin{array}{l}-0.052 \\
(0.314) \\
\end{array}$ & & $\begin{array}{l}0.819^{* * *} \\
(0.290)\end{array}$ & & $\begin{array}{l}0.589^{* * *} \\
(0.218)\end{array}$ & & $\begin{array}{l}-1.033^{*} \\
(0.583)\end{array}$ & \\
\hline \multicolumn{11}{|l|}{ Financial market regulation } \\
\hline $\begin{array}{l}\text { Credit to the private sector } \\
\text { (\% of GDP) }\end{array}$ & $\begin{array}{l}-3.954^{\star * *} \\
(1.262)\end{array}$ & $\begin{array}{c}0.593^{*} \\
(0.315)\end{array}$ & $\begin{array}{l}-2.987^{\star \star} \\
(1.362)\end{array}$ & $\begin{array}{l}-1.133^{\star *} \\
(0.470)\end{array}$ & $\begin{array}{c}1.842 \\
(1.180)\end{array}$ & $\begin{array}{l}1.126^{* \star} \\
(0.451)\end{array}$ & $\begin{aligned} 1.896^{*} \\
(1.019)\end{aligned}$ & $\begin{array}{l}0.970^{* *} \\
(0.452)\end{array}$ & $\begin{array}{l}-2.930 \\
(1.848)\end{array}$ & \\
\hline $\begin{array}{l}\text { Stock Market Capitalization } \\
\text { (\% of GDP) }\end{array}$ & $\begin{array}{l}-1.744 \\
(2.391)\end{array}$ & $\begin{array}{r}-0.342 \\
(0.544)\end{array}$ & $\begin{array}{l}-0.821 \\
(1.421)\end{array}$ & $\begin{array}{l}-0.389 \\
(0.720)\end{array}$ & $\begin{array}{c}0.181 \\
(1.435)\end{array}$ & & $\begin{array}{l}1.979 \\
(2.220)\end{array}$ & $\begin{array}{l}1.036^{* *} \\
(0.498)\end{array}$ & $\begin{array}{l}-2.636 \\
(1.918)\end{array}$ & \\
\hline $\begin{array}{l}\text { Stock market trade } \\
(\% \text { of GDP) }\end{array}$ & $\begin{array}{l}-1.085 \\
(1.184)\end{array}$ & $\begin{array}{l}-0.594^{* * *} \\
(0.206)\end{array}$ & $\begin{array}{l}-1.065 \\
(0.662)\end{array}$ & $\begin{array}{l}-0.442^{* *} \\
(0.214)\end{array}$ & $\begin{array}{l}-0.332 \\
(0.697)\end{array}$ & & $\begin{array}{l}0.250 \\
(0.692)\end{array}$ & $\begin{array}{l}0.312^{*} \\
(0.179)\end{array}$ & $\begin{array}{l}-1.057 \\
(0.902)\end{array}$ & $\begin{array}{l}-0.692^{*} \\
(0.326)\end{array}$ \\
\hline Financial reform index & $\begin{array}{r}0.016 \\
(0.087) \\
\end{array}$ & & $\begin{array}{l}-0.076 \\
(0.104)\end{array}$ & & $\begin{array}{c}0.146 \\
(0.131)\end{array}$ & & $\begin{array}{c}0.153 \\
(0.117) \\
\end{array}$ & & $\begin{array}{l}-0.096 \\
(0.168)\end{array}$ & \\
\hline \multicolumn{11}{|l|}{ Product market regulation } \\
\hline $\begin{array}{l}\text { Regulation in seven non- } \\
\text { manufacturing sectors }\end{array}$ & & & & & $\begin{array}{c}0.150 \\
(0.375)\end{array}$ & $\begin{array}{l}-0.543^{* *} \\
(0.221)\end{array}$ & $\begin{array}{c}0.270 \\
(0.355)\end{array}$ & $\begin{array}{l}-1.002^{* *} \\
(0.390)\end{array}$ & $\begin{array}{l}-0.866 \\
(0.598)\end{array}$ & \\
\hline
\end{tabular}

Note: Robust standard errors in parentheses. *, ** and ${ }^{* * *}$ denote significance at the $10 \%, 5 \%$ and $1 \%$ significance level. SAVT, SAVP, INVT, INVP, and CA denote the GDP shares of respectively total saving, private saving, total investment, private investment, and the current account balance. $\mathrm{LR}=$ long run, $\mathrm{SR}=$ short run. For social welfare programs no short-run dynamics are included in the specifications due to linear interpolation of the data. All specifications include country and period fixed effects. 
Table 4. The impact of structural policies on saving, investment and current accounts - OECD/non-OECD sample

Baseline equations augmented with structural policy indicators

\begin{tabular}{l|c|c|c}
\hline & INVT & SAVT & CA \\
\hline Employment law index & -2.130 & -3.201 & -4.204 \\
Unemployment benefits & $(2.870)$ & $(5.230)$ & $(5.719)$ \\
Public health expenditure (\% of GDP) & & -2.832 & -1.834 \\
& & $(3.947)$ & $(3.275)$ \\
Ease of doing business index & & -0.725 & $-0.992^{* *}$ \\
& & $(0.491)$ & $(0.465)$ \\
Cost of starting a business (\% of GNI) & -0.014 & & -0.003 \\
& $(0.012)$ & & $(0.026)$ \\
Days required to start a business & $-0.009^{* *}$ & & -0.005 \\
& $(0.004)$ & & $(0.004)$ \\
Number of procedures to register a business & 0.008 & & 0.015 \\
& $(0.010)$ & & $(0.017)$ \\
Financial reform index & $-0.229^{* *}$ & & 0.245 \\
\hline
\end{tabular}

Note: Robust standard errors in parentheses. * ${ }^{* *}$ and ${ }^{* * *}$ denote significance at the $10 \%, 5 \%$ and $1 \%$ significance level. SAVT, INVT, and CA denote the GDP shares of respectively total saving, total investment, and the current account balance.

22. These findings are broadly consistent with micro studies on the saving impact of social welfare schemes. Higher unemployment benefit replacement rates have been found to reduce household saving on US state-level data (Engen and Gruber, 2001). ${ }^{45}$ Likewise, several studies show that a broader coverage and better quality of public health insurance schemes discourage private saving (e.g. de Nardi et al., 2006; Jappelli et al., 2006; Maynard and Qiu, 2009; Chou et al., 2003), though the size of the effect differs across different types of households. Regarding China more specifically, there is recent evidence that government health spending (or lack thereof) affects individual household saving rates (OECD, 2010c; Barnett and Brooks, 2010; Chamon and Prasad, 2010). Other relevant design features of social welfare systems include the asset tests associated with means-tested social programs, which may discourage saving in order to qualify for benefits (see Hubbard et al., 1995, Gruber and Yellowitz, 1999; Nam, 2008; and McKernan et al., 2007 for some evidence for the United States). ${ }^{46}$

45. According to Engen and Gruber (2001), cutting the unemployment benefit replacement rate by half would increase gross financial asset holdings by $14 \%$ for the average worker.

46. Specifically, the authors examine the means tests of the AFDC/TANF programs (Aid to Families with Dependent Children \& Temporary Assistance for Needy Families) and of Medicaid. However, Hurst and Ziliak (2006) and Sullivan (2006), also looking at the AFDC/TANF programs, cannot find any evidence that means tests discourage asset holding. 
ECO/WKP(2010)71

Table 5. Results for interaction effects

\begin{tabular}{|c|c|c|c|}
\hline \multicolumn{4}{|l|}{ OECD/non-OECD sample } \\
\hline & SAVT & SAVT & SAVT \\
\hline Real interest rate & $\begin{array}{l}-0.076 \\
(0.063)\end{array}$ & $\begin{array}{l}-0.603^{\star \star *} \\
(0.182)\end{array}$ & $\begin{array}{l}-0.118^{\star \star *} \\
(0.045)\end{array}$ \\
\hline Productivity growth & $\begin{array}{c}0.532 \\
(0.324)\end{array}$ & $\begin{array}{c}0.506 \\
(0.582)\end{array}$ & $\begin{array}{c}0.277 \\
(0.282)\end{array}$ \\
\hline Change in terms of trade & $\begin{array}{c}0.333^{* *} \\
(0.132)\end{array}$ & $\begin{array}{c}0.289 \\
(0.260)\end{array}$ & $\begin{array}{c}0.115 \\
(0.149)\end{array}$ \\
\hline Old-age dependency ratio & $\begin{array}{l}-0.461^{* *} \\
(0.223)\end{array}$ & $\begin{array}{l}-0.336 \\
(0.266)\end{array}$ & $\begin{array}{l}-0.493^{\star \star \star} \\
(0.149)\end{array}$ \\
\hline Youth dependency ratio & $\begin{array}{l}-0.286^{\star * *} \\
(0.053)\end{array}$ & $\begin{array}{l}-0.205^{\star * *} \\
(0.059)\end{array}$ & $\begin{array}{l}-0.223^{\star \star \star} \\
(0.043)\end{array}$ \\
\hline Public health expenditure (\% of GDP) & $\begin{array}{l}-1.128^{\star *} \\
(0.558)\end{array}$ & & \\
\hline Public health expenditure (\% of GDP) squared & $\begin{array}{l}0.375^{\star * *} \\
(0.137)\end{array}$ & & \\
\hline Employment law index & & $\begin{array}{l}-4.230 \\
(5.332)\end{array}$ & \\
\hline Unemployment benefits & & $\begin{array}{l}-1.373 \\
(3.993)\end{array}$ & \\
\hline Employment law index * Unemployment benefits & & $\begin{array}{c}23.270^{*} \\
(13.376)\end{array}$ & \\
\hline Financial reform index & & & $\begin{array}{l}-0.444^{* *} \\
(0.222)\end{array}$ \\
\hline GDP per capita relative to the US & & & $\begin{array}{c}6.759^{*} \\
(3.993)\end{array}$ \\
\hline Financial reform index * GDP per capita relative to the US & & & $\begin{array}{c}0.176 \\
(0.627)\end{array}$ \\
\hline$F$-test for joint significance of policy variables and interaction term ( $p$-value) & 0.017 & 0.248 & 0.077 \\
\hline Number of cross sections & 90 & 54 & 58 \\
\hline Number of observations & 170 & 54 & 161 \\
\hline
\end{tabular}

Note: Robust standard errors in parentheses. ${ }^{*},{ }^{* *}$ and ${ }^{* * *}$ denote significance at the $10 \%, 5 \%$ and $1 \%$ significance level. SAVT denotes the GDP share of total saving.

23. Regarding pension reforms, the present analysis suggests that increasing the statutory retirement age by one-year reduces total and private saving by around half a percentage point of GDP in the medium to long run (Table 3), a finding that is robust to variations in the sample (Table A1.9 and Figures A1.3 and A1.4 in Annex 1). ${ }^{47}$ This negative relationship is consistent with the notion that a higher retirement age prolongs the period during which to accumulate wealth and shortens the period during which to live of that wealth, and it is also supported by other recent studies (e.g. Kirsanova and Sefton, 2007). As regards pension benefits, the existing empirical evidence indicates that a cut in benefits is associated with higher private saving rates in the aftermath of the reform. Exploiting the Italian pension reform of 1992, Attanasio and Brugiavini (2003) demonstrate that this effect is particularly high for workers between 35 and 45. Feng et al. (2009) show that the pension reform for enterprise employees implemented in China in the late 1990s boosted the household saving rate. ${ }^{48}$ The scarce evidence that exists on the relative impact of unfunded

47. While the variable is insignificant in the specification with country-specific time trends (see Table A1.8 in Annex 1), this result may be due to the specific way in which such reforms are implemented - namely stepwise increases in the retirement age phased in over a period of several years - which make the variable essentially collinear to a linear combination of a country-specific dummy and a country-specific trend.

48. Attanasio and Brugiavini (2003) look at a simultaneous rise in the retirement age and a cut in the level of benefits. The positive relationship could thus be interpreted in the sense that the effect of the benefit cut dominates or that the analysis captures the immediate impact of an increase in the retirement age with individuals increasing their saving in order to self-finance a retirement ahead of the new retirement age so as to stick to their pre-reform retirement plans. 
versus funded schemes is more mixed, with tentative evidence that countries with a pay-as-you-go system tend to have lower saving rates (Samwick, 2000).

\section{Figure 3. Results for interaction effects - OECD/non-OECD sample}
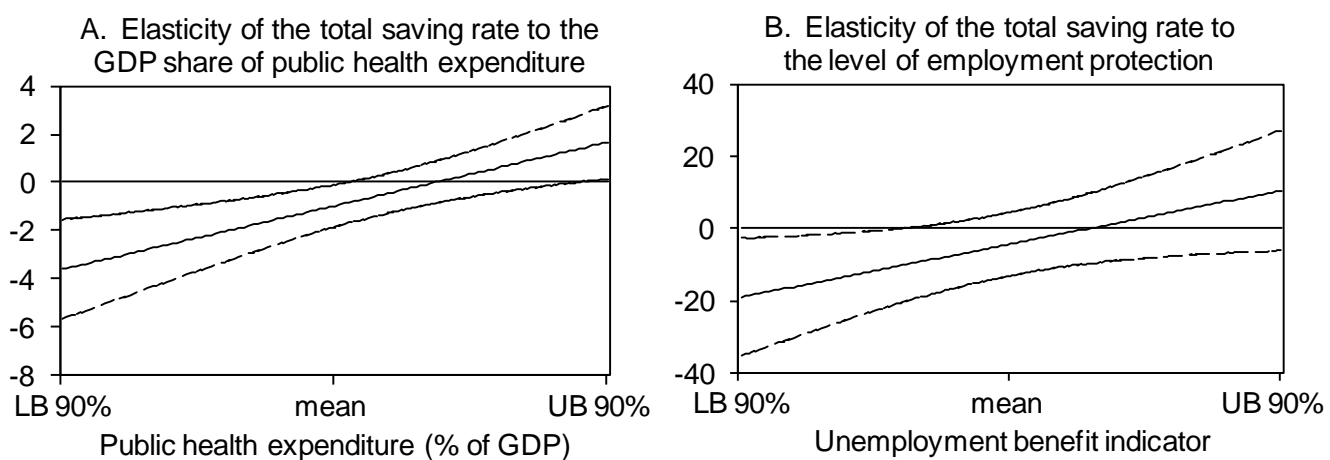

C. Elasticity of the total saving rate to

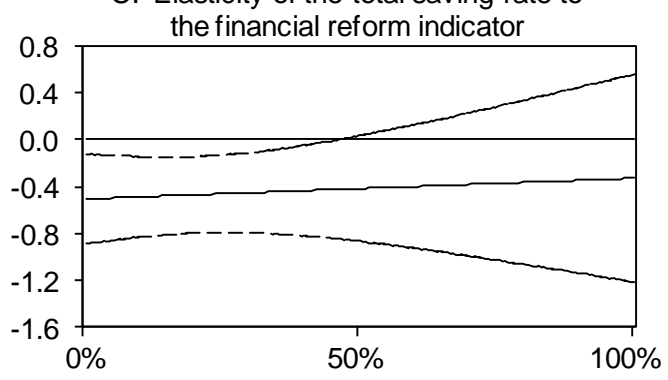

GDP per capita relative to the US (2005 PPP USD)

Note: mean, LB $90 \%$ and UB $90 \%$ denote respectively the sample mean and the lower and upper bounds of a $90 \%$ confidence interval around the mean of the variable considered. A higher score on the unemployment benefit indicator (panel B) means better income protection in case of job loss.

Source: Calculations based on coefficient estimates presented in Table 5.

\subsection{The impact of labour market reform}

24. There is ample evidence at the micro level that higher income uncertainty is associated with larger wealth holdings by households (or higher saving/lower consumption), though the size of the effect appears to differ widely across studies, potentially related to the focus on different countries. ${ }^{49}$ The empirical analysis conducted in this paper does not provide strong evidence that the stringency of employment protection legislation (EPL) impacts the private or total saving rate in OECD countries. ${ }^{50,51}$

49. Income risk is typically measured by either the variance of income over time (e.g. Guariglia and Rossi, 2002; Zhou, 2003; Hurst et al., 2005; Bartzsch, 2006) or by self-reported information on the future employment and/or earnings outlook (e.g. Lusardi, 1997; Harris et al., 2002; Carroll et al., 2003; Benito, 2006). Regarding the magnitude of the effect, Lusardi (1997) finds, for example, that precautionary wealth accumulation ranges from one-fifth to one-fourth of the total wealth accumulation of Italian households, whereas Hurst et al. (2005) conclude that precautionary wealth accounts for less than $10 \%$ of total household wealth in the United States.

50. Although the variable comes out as significant in the specification that features country-specific time trends (see Table A1.8 in Annex 1), this result does not appear to be robust across different country samples.

51. Bassanini et al. (2010) point out that the indicator of employment protection on temporary contracts must be handled with care due to strong enforcement issues in several OECD countries. However, restricting the sample to countries with good law enforcement - defined as those with an average score on two 
The insignificance of this variable may reflect two offsetting effects, as more stringent protection reduces the probability of job loss, but also lengthens the expected unemployment spell after dismissal. This explanation is consistent with existing evidence that perceived job security is actually weaker in high-EPL countries (Clark and Postel-Vinay, 2009). For the broader country dataset, however, there is some evidence that lower employment protection is associated with higher saving rates, but only in countries with low or no unemployment benefits (Table 5 and Figure 3, panel B). ${ }^{52}$ Other labour market indicators (e.g. the level of the minimum wage and the bargaining power of unions) are not found to have a significant influence on saving rates (results not shown).

25. As regards investment, employment protection is the only one of the labour market indicators considered that is found to have a robust impact, and only for the sample of OECD countries. Stricter EPL appears to be associated with higher GDP shares of both private and total investment, a finding that applies to both the overall index of employment protection and the sub-index for temporary workers (Table 3). ${ }^{53,54}$ One potential explanation for this result is that while the implicit and explicit costs associated with stronger protection might discourage FDI to countries with higher EPL ${ }^{55}$ domestic firms may instead react by substituting capital for labour, ${ }^{56}$ and the latter effect may dominate on average across OECD countries. The point estimates imply that a one-standard-deviation rise in the EPL indicator boosts private investment by around half a percentage point of GDP and total investment by around 1 percentage point of GDP in the medium to long run. ${ }^{57}$ The current account regressions point to a negative link between a country's level of employment protection and its current account position, in line with the favourable investment effects of strict EPL. ${ }^{58,59}$

enforcement indicators (integrity of the judicial system and the enforcement of contracts) that is above the median of the sample (see Bassanini et al., 2010) - does not change the results.

52. No evidence of such an interaction effect is found for the OECD sample (results not shown), possibly reflecting the higher level of benefits in these countries (which, during the sample period, was generally above the significance threshold found for the broader country set).

53. However, higher employment protection may be detrimental to investment in specific sectors. For example, OECD (2003b) provides some indicative evidence that ICT investment is lower in countries with strong EPL, which may reflect higher workforce adjustment costs that limit firms' profitability from investments.

54. The finding is robust to most (though not all) variations in the specification (see Tables A1.8 and A1.11) and also to variations in the sample, including the omission of countries with poor law enforcement (see Table A1.9 and Figures A1.15 and A1.16).

55. Detrimental effects of strict EPL on FDI inflows are confirmed by several recent studies (e.g. Haaland et al., 2003; Nicoletti et al., 2003; Görg, 2005; Javoric and Spatareanu, 2005).

56. There is even some evidence that strict employment protection in a firm's home country makes this firm reluctant to relocate abroad, at least temporarily (Dewit et al., 2009).

57. By construction, the values of the EPL indicator range from 0 to 6 . In 2008, the average value across all OECD countries was 1.94 and the standard deviation was equal to 0.85 . For the average OECD country, a decline in the EPL indicator by one standard deviation would be equivalent to bringing it down to the stance observed, on average, in the five most liberal OECD countries (Australia, Canada, Ireland, the United Kingdom, and the United States).

58. The EPL indicators are, however, not statistically significant in the specification that features countryspecific time trends (Table A1.8).

59. There is no evidence that labour market reforms affect the speed at which investment adjusts to its new equilibrium level following a macroeconomic shock to the economy (results not shown). 


\subsection{The impact of product market reform}

26. Product market reform can influence investment in several conflicting ways (Alesina et al., 2005): i) reductions in entry barriers may increase output and capital accumulation by reducing the markup of prices over marginal costs; $i$ i) reductions in red tape and other forms of regulatory burdens can lower the costs of expanding the capital stock for incumbent firms and thus enhance their capacity to respond to changes in fundamentals; ${ }^{60}$ iii) in the presence of information asymmetries, internal and external sources of financing may not be perfectly substitutable, and reductions in mark-ups may depress investment; $i v$ ) to the extent that product market reforms are accompanied by the privatization of public enterprises that had been heavy investors, investment may fall despite the decline in the shadow cost of entry; $v$ ) product market reforms may affect the GDP share of investment by altering the sectoral specialization of the economy towards sectors that are less/more capital intensive or rely less/more on investment goods with a high rate of depreciation. ${ }^{61}$

27. The empirical analysis suggests that product market deregulation boosts private investment and total investment, but that this effect vanishes after a few years (Table 3) ${ }^{62}$ Taken at face value, the magnitude of the coefficient implies that an improvement in the regulation index similar in size to that achieved in the average OECD country over 1998-2008 is associated with an increase in total investment by about 0.4 percentage points of GDP in the year following the reform (Figure A1.7). ${ }^{63}$ The level of product market regulation does, however, not appear to affect the speed at which the investment-to-GDP ratio adjusts to its new equilibrium level following an exogenous shock. ${ }^{64}$ Previous studies on the issue also generally conclude that a reduction in regulation is associated with higher investment. Alesina et al. (2005) find for a panel of OECD countries that this effect is particularly large for a removal of entry barriers. Regarding public ownership, the authors find that privatization is associated with higher investment rates, suggesting that privatization is, on average, associated with lower shadow costs of entry and that this outweighs the effect of less overinvestment. Vartia (2008) and Griffith and Harrison (2004) also provide evidence that less regulation is associated with a higher investment rate. As for the current

60. The more responsive investment is to the marginal profitability, the higher the steady state capital stock.

61. In the latter case only the gross investment rate is affected, whereas in all other cases it is also the net investment rate that changes.

62. Although the specification with country-specific time trends indicates that product market deregulation is detrimental to investment in the medium to long run, this result appears to be driven by a small number of countries. Previous studies on the link between product market regulation and investment also use specifications without time trends (e.g. Vartia, 2008).

63. Figure 4 shows the investment effect of a one-standard-deviation increase in the indicator of regulation in seven non-manufacturing industries. By construction, the values of the indicator on regulation in seven non-manufacturing industries range from 0 to 6 . In 2007, the average value across all OECD countries was 2.13 and the standard deviation was equal to 0.63 . For the average OECD country, a decline in the regulation indicator by one standard deviation would be equivalent to bringing it close to the stance observed in some of the most liberal OECD countries (Australia, Denmark and Spain, where regulation is estimated to be somewhat more stringent than in the most liberal countries, Germany and the United Kingdom).

64. The regressions for the broader country dataset which make use of the World Bank's Doing Business indicators also point to a possible negative link between some regulations and investment (Table 4). 
account, the empirical analysis does not provide any robust evidence for an impact of product market regulation. ${ }^{65}$

\subsection{The impact of financial market reform}

28. The impact of financial market reform on the saving behaviour of firms and households is theoretically ambiguous. On the one hand, reforms that increase the depth and/or sophistication of domestic financial markets might reduce saving by relaxing borrowing constraints and by lowering the need for precautionary saving through better portfolio diversification, at least provided adequate prudential regulation is in place. On the other hand, financial market development might increase saving by widening saving opportunities, which should allow the supply of financial services to better match individual preferences, risk aversion and income profiles. In addition, financial market development might influence saving by altering rates of return and lending margins (e.g. by lowering transaction costs), with the direction of the impact depending on the relative strength of the substitution and income effects.

29. Financial market regulation indicators are inherently difficult to construct with many studies not using policy indicators but intermediate outcome indicators which suffer from potential endogeneity. For the OECD sample, the study relies on both outcome and policy indicators to measure financial market reform, and the results appear to be highly sensitive to the choice of the indicator. While the outcome indicators tend to point to a negative relationship between financial market development and saving rates, this is not confirmed by the financial reform index of Abiad et al. (2010), which combines a wide range of policy indicators on financial sophistication and liberalization. ${ }^{66}$ These mixed results are consistent with the existing empirical literature. ${ }^{67}$ One possible explanation for the mixed results is the existence of thresholds effects whereby the negative effect from the removal of borrowing constraints may dominate in early stages of financial development, whereas the positive impact from broader supply and expected returns may become predominant at later stages (Ferrucci and Miralles, 2007). The analysis for the broader sample that includes both OECD and developing countries lends some support to this explanation, with the financial reform index by Abiad at al. (2010) found to be significantly negatively related to the total saving rate (Table 4). The effect appears to hold only for countries with GDP per capita levels below half of the US level (Table 5 and Figure 3, panel C). There is no robust evidence that the depth and sophistication of financial markets influences the saving effects of other structural policies, nor that it affects the speeds at which households and firms adapt their saving behaviour in response to changes in fundamentals.

30. Financial market deregulation should stimulate investment, not least by lowering the cost of acquiring and evaluating information on prospective projects and by reducing the risk of resource mismanagement through easier monitoring of investments (OECD, 2003a). However, to the extent that financial repression is associated with households supplying cheap capital to enterprises, liberalisation may raise the cost of capital and thus lower investment. As stressed by Caballero (2006) and Caballero et al. (2008), financial market imperfections in emerging and developing countries might be one reason why these countries have invested in advanced countries such as the US rather than domestically. While a positive link between financial development and investment is supported by several recent studies

65. By reducing precautionary saving through higher job turnover, product market deregulation may also affect the saving rate.

66. The outcome indicators are the GDP shares of stock market capitalization and stock market trade (which have the disadvantage of being driven by changes in the valuation of listed companies, thus capturing wealth effects) and credit to the private sector (which is likely to be endogenous to saving decisions).

67. For example, Loayza et al. (2000), Bandiera et al. (2000) and Sarantis and Stewart (2001) find a negative impact of financial market development on saving rates, whereas Cheung et al. (2010) and Hüfner and Koske (2010) are unable to establish a significant link. 
(e.g. OECD, 2003a; Cheung et al., 2010; Dorrucci et al., 2009), ${ }^{68}$ the empirical analysis conducted in this paper yields somewhat ambiguous results, with the coefficient either positive or insignificant depending on the choice of the proxy for financial market regulation and the specification. ${ }^{69}$ Similarly, this study does not find strong evidence that financial market development weakens the current account position, unlike several other studies (Chinn and Ito, 2007; Kennedy and Sløk, 2005; Dorrucci et al., 2009). ${ }^{70}$

\subsection{The impact of tax reform}

31. Tax reforms may affect household saving through a variety of different channels, not least via the after-tax rate of return on saving or via asymmetric tax treatment of different types of capital income (e.g. tax deductibility of interest expenses on loans in the absence of taxation of imputed rent). While the limited availability of time series data on capital gain tax rates and the interest rate deductibility of mortgages does not allow an investigation of these effects here, a number of individual-country studies have concluded that a reduction in the after-tax rate of return (e.g. by cutting down tax deduction of interest expenses) boosts the saving rate (e.g. Summers, 1984, for the United States; Koskela and Virén, 1994, for Denmark, Sweden and Finland). To the extent that higher-income households have a higher propensity to save, a more progressive income tax system may be associated with a lower aggregate saving rate, ceteris paribus. The empirical analysis does not yield robust evidence in favour of such a link, with the coefficient on income tax progressivity being significantly negative or insignificant, depending on the precise specification and sample (results not shown). As for tax-deferred retirement saving vehicles, several studies find that they boost private saving (Poterba et al., 1996; Rossi, 2009), whilst others point to sizeable crowding-out, at least for some types of households (Attanasio et al., 2004; Corneo et al., 2009). Looking at various pension-unrelated savings accounts, OECD (2007) concludes that tax-preferred accounts create new savings only when moderate-income households participate in them.

32. Lower corporate tax rates (or larger capital depreciation allowances) should raise investment by reducing the user cost of capital. ${ }^{71}$ Although the significant negative coefficient on the (not tax-adjusted) user cost of capital variable in the baseline specification is consistent with this link, the empirical analysis in this paper does not find support for a direct negative effect of corporate taxes when introducing them as separate explanatory variables in the investment equations. ${ }^{72}$ Studies that make use of sector or firm-level

68. Moreover, Henry (1999) provides some evidence that stock market liberalization leads to private investment booms in less developed countries.

69. The specifications with time trends even point to a detrimental effect of financial market reforms in the medium to long-run, though the significance of this effect hinges crucially on the set of countries that are included in the regression.

70. This negative effect of financial development on current accounts has been found to be greater in the presence of a strong legal system that increases the returns on investment through increased transparency and predictability of economic activity (Chinn and Ito, 2007).

71. If capital markets are not perfect there might be an additional effect beyond the user cost as taxes affect the after-tax earnings from existing projects and hence the internal funds available to finance future investment (see the discussion in Section 3).

72. As pointed out by Hassett and Hubbard (2002), investment and tax policy tend to move together over the business cycle, which makes it difficult to establish the user cost effect based on aggregate data. For example, policymakers introduce investment tax credits when investment is perceived to be low and remove them when investment is perceived to be high (Cummins et al., 1994; OECD, 2009). 
data generally find that lower corporate tax rates or higher depreciation allowances are associated with higher investment (e.g. Vartia, 2008; Schwellnus and Arnold, 2008; Hassett and Hubbard, 2002). ${ }^{73}$

\section{Quantifying the impact of policy reforms on current account imbalances}

33. The empirical results presented in the previous section (see Table 6 for an overview) are used to obtain illustrative estimates of the side effects of possible growth-enhancing policy reform packages on saving-investment gaps. While the reform packages are chosen to yield a double dividend by both boosting growth and reducing saving-investment gaps, some other desirable reforms ignored in the simulations may well be associated with a widening of external positions. Given the likelihood of and need for major fiscal tightening across the OECD over the coming years, the packages also incorporate fiscal tightening scenarios. The (dynamic) simulations rely on the coefficient estimates obtained for the saving and investment rate equations in Table 1 , which prove to be more robust than the current account equations. ${ }^{74}$ For the purpose of the simulations, the equations are transformed into deviations from the cross-country average to account for the fact that relative (rather than absolute) movements in macroeconomic and structural policy settings drive saving-investment gaps in equilibrium. A total of four scenarios are created, two global scenarios that look at 27 OECD countries ${ }^{75}$ plus China, and two euro area scenarios. ${ }^{76}$ In both cases, one scenario exclusively considers changes in fiscal positions, while the other also assumes the implementation of structural reforms. The results of this rather simplistic simulation exercise need to be interpreted with care. Most importantly, the simulations treat saving and investment separately and abstract from possibly heterogeneous interest rate responses (in particular to fiscal tightening). Specific caution is warranted when interpreting the results for China since the simulations mostly rely on the coefficient estimates obtained with the OECD panel dataset. ${ }^{77}$ Moreover, some of the coefficients used in the simulations are rather imprecisely estimated, meaning that the precise magnitudes of the saving-investment gap effects of policy reforms are surrounded by a high degree of uncertainty.

34. Figure 4 shows the simulated response of saving rates in selected countries under both the global and the euro area fiscal scenario (relative to a no-change baseline), and Figure 5 illustrates the implied impact on the size of global and intra-euro-area imbalances (measured as the GDP-weighted sum of the absolute saving-investment-gap-to-GDP ratios of all countries in the region). ${ }^{78}$ All countries with the

73. Tax policies affect individual firms differently as the composition of the capital stock varies across firms, making it possible to identify the effect of tax policies based on differences in investment response across different types of firms.

74. These coefficient estimates from the baseline specifications in Table 1 are combined with coefficient estimates from other specifications in order to simulate the impact of structural reforms. An overview on the precise specifications used is provided in Table 7.

75. All OECD countries with the exception of Chile, Israel, Luxembourg, Mexico, Slovenia and Turkey, which are excluded due to data availability problems.

76. The results of the scenario analysis are consistent with any kind of exchange rate regime. It is implicitly assumed that the exchange rate adjusts so as to make the current account balance equal to the savinginvestment gap.

77. Although the regressions for the OECD/non-OECD sample do not provide evidence that the effects of policies differ significantly between OECD and non-OECD countries, it cannot be ruled out that the elasticities would be different for a specific country such as China. Indeed, the size of the sample does not allow to properly test for coefficient heterogeneity for one particular country.

78. This measure of imbalances does not account for possible non-linearities (especially threshold effects), thus ignoring for instance that larger imbalances may be associated with disproportionally larger global systemic risk. However, giving more weight to larger surpluses and deficits by using the square instead of the absolute value of individual countries' current account balances yields qualitatively similar results. 
exception of China (which is assumed to leave its budget balance unchanged) are assumed to adjust their underlying primary balance so as to stabilise the debt-to-GDP ratio over the long-term, as embodied in the long-term baseline scenario presented in the OECD Economic Outlook 87. ${ }^{79}$ Fiscal tightening is implemented in equal steps over a period of 15 years (see Table 7 for an overview of the magnitude and timing of fiscal measures).

Table 6. Overview of the estimated effects of structural policies on saving, investment and current accounts

\begin{tabular}{|c|c|c|c|}
\hline & $\begin{array}{c}\text { Total } \\
\text { saving }\end{array}$ & $\begin{array}{c}\text { Total } \\
\text { investment }\end{array}$ & $\begin{array}{l}\text { Current } \\
\text { account }\end{array}$ \\
\hline \multicolumn{4}{|l|}{ Macroeconomic conditions } \\
\hline Increase in productivity growth & + & + & - \\
\hline Increase in the user cost of capital & & - & $(+)$ \\
\hline Increase in the growth rate of working age population & & + & - \\
\hline Increase in the rate of change of the terms of trade & + & & + \\
\hline Increase in the real rate of interest & - & & $(-)$ \\
\hline Increase in the old-age dependency ratio & - & & - \\
\hline Increase in the youth dependency ratio & + & & + \\
\hline Increase in government net lending & + & & $(+)$ \\
\hline \multicolumn{4}{|l|}{ Structural policies } \\
\hline Improvement in coverage/quality of social welfare system & - & & - \\
\hline Increase in retirement age & - & & $(-)$ \\
\hline Lowering of employment protection & 0 & - & + \\
\hline Product market deregulation & & + & $(-)$ \\
\hline Financial market deregulation & $0 /-$ & $0 /+$ & $(0 /-)$ \\
\hline
\end{tabular}

Note: +, -, 0 denote respectively a significant rise, a significance fall, and no significant change in the dependent variable. The reported results refer to the medium- to long-run effect in all cases but product market regulation reform, where the short-run effect is shown. Results for the current account regressions are reported in brackets if the findings from the preferred saving and investment equations imply an impact which cannot be detected in the current account estimates. The lower half of the table reports the impact of structural policies over and above any impact that works through changes in macroeconomic conditions (e.g. product market deregulation may raise investment not only directly but also indirectly through higher productivity growth).

35. Overall, as fiscal tightening would be stronger in deficit countries than in surplus countries, global and intra-euro-area imbalances would narrow as a result of fiscal consolidation, although only to a limited extent (Figure 5). Fiscal consolidation in the United States would raise the aggregate saving rate, thereby reducing the country's saving-investment gap. However, due to private saving offsets and due to the simultaneous fiscal tightening in other countries, the gap would decline by less than the improvement in the government's budget balance, i.e. by just 0.6 percentage points of GDP over the next decade and by about $1 \frac{1 / 4}{4}$ percentage points of GDP over the full 25 year simulation horizon considered here. In Japan, fiscal tightening would raise the currently positive saving-investment gap by slightly over half a percentage point of GDP over the next two decades. In Germany, the positive saving-investment gap would fall, reflecting the smaller effort needed to stabilize the debt-to-GDP ratio compared with other countries. As for other euro area countries, fiscal tightening would, for example, reduce the saving-investment gap in Spain, Portugal and Greece.

36. The second set of scenarios investigates how saving-investment gaps would be affected if countries were to implement structural reforms in addition to the fiscal measures. The reform packages that underlie the scenarios are designed with the view to reducing current account imbalances in countries with sizeable deficits or surpluses. However, other desirable, growth-enhancing structural reforms ignored here

79. However, the relatively modest pace of the assumed consolidation is such that in most cases the debt-toGDP ratio first increases further before stabilising. 
may or may not be associated with a reduction in saving-investment gaps ${ }^{80}$ In the global scenario, Japan and Germany are assumed to deregulate their product markets so as to align their level of regulation with OECD best practice (defined as the average of the top three performing countries). In addition, China is assumed to implement product market reforms over the next decade that are similar in magnitude to those that happened in OECD countries over the period 1998 to 2008, to implement over the next decade financial market reforms that are similar in magnitude to those undertaken by China between 1995 and 2005 and to increase social spending on health by 2 percentage points of GDP, split equally over the first and second years. The increase in public health spending is assumed to be fiscally neutral, so that the government budget balance remains unchanged. For the euro area scenario it is assumed that Germany deregulates its product markets and that Spain, Portugal and Greece deregulate their labour markets, aligning the level of their EPL indicator to OECD best practice (see Table 7 for an overview of the magnitudes and timing of simulated structural reforms). This second set of scenarios accounts both for the direct effect of product market reforms, based on the preferred specifications from Section 4, and for their indirect impact via higher productivity growth, using estimates by Boulhol et al. (2008). ${ }^{81}$

Figure 4. Simulated current account impact of illustrative structural reforms and fiscal consolidation scenarios

Percentage point deviation from no-change scenario
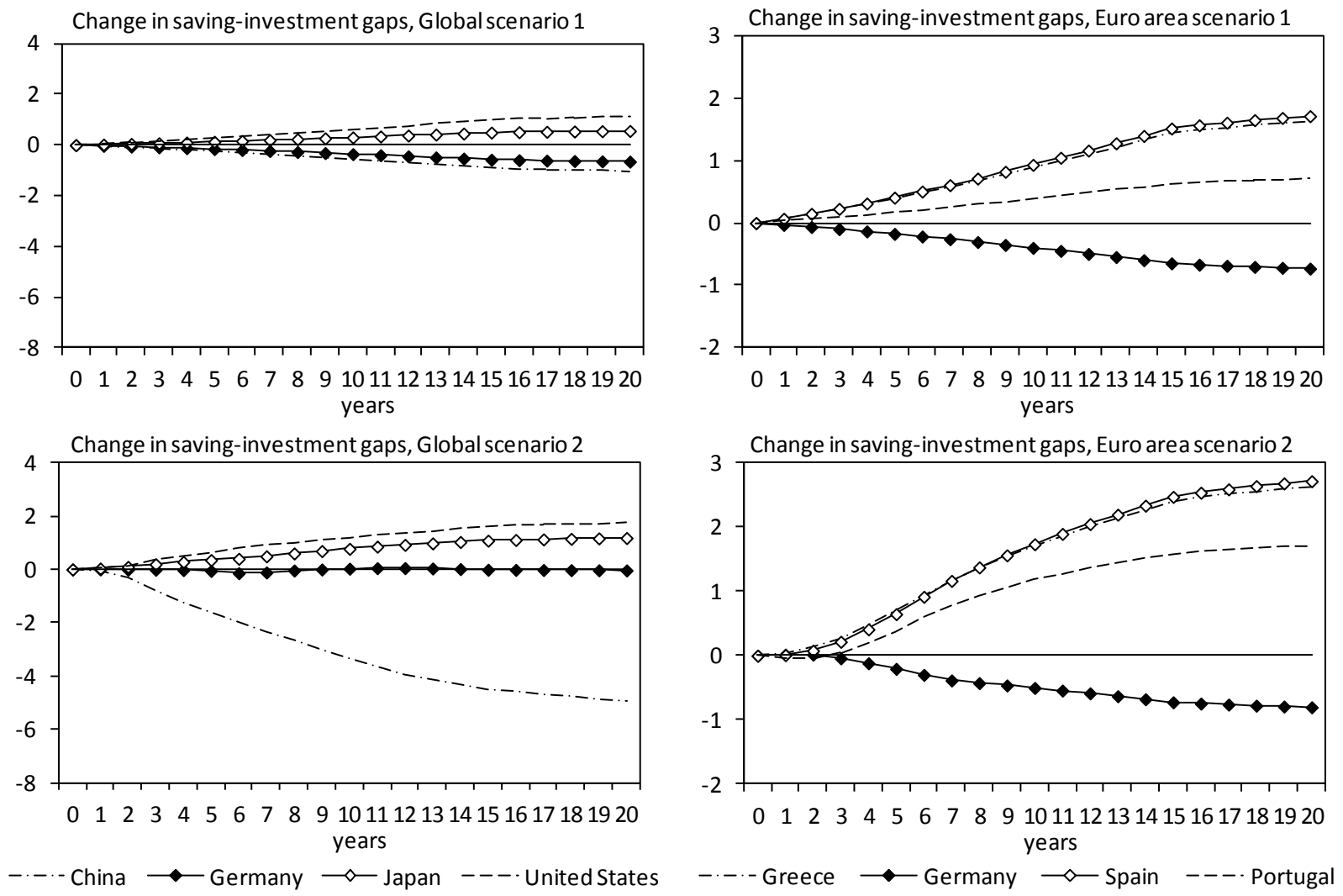

Note: Global scenario 1 and Euro area scenario 1 only feature fiscal adjustment, whereas Global scenario 2 and Euro area scenario 2 feature fiscal adjustment and structural reforms.

80. For example, if all OECD countries were to undertake product and labour market reforms so as to align their level of regulation with OECD best practice, the decline in global imbalances would be somewhat larger than found here.

81. See Table 3, column 1 in Bouhol et al. (2008). 
ECO/WKP(2010)71

Table 7. Assumptions underlying the scenario analysis

\begin{tabular}{|c|c|c|c|c|c|}
\hline & $\begin{array}{l}\text { Change in government net } \\
\text { lending }\end{array}$ & $\begin{array}{l}\text { Product market reform (change in } \\
\text { economy-wide PMR indicator) }\end{array}$ & $\begin{array}{l}\text { Change in public social } \\
\text { spending on health }\end{array}$ & $\begin{array}{l}\text { Financial market reform } \\
\text { (change in FRI) }\end{array}$ & $\begin{array}{l}\text { Labour market reform } \\
\text { (change in EPL indicator) }\end{array}$ \\
\hline \multicolumn{6}{|l|}{ Global scenarios } \\
\hline United States & $\begin{array}{c}\text { 7.3\% of GDP, } \\
\text { split evenly over first } 15 \text { years }\end{array}$ & & & & \\
\hline Japan & $\begin{array}{l}5.4 \% \text { of GDP, } \\
\text { split evenly over first } 15 \text { years }\end{array}$ & $\begin{array}{l}-0.25 \text {, } \\
\text { split evenly over first } 5 \text { years }\end{array}$ & & & \\
\hline Germany & $\begin{array}{c}1.3 \% \text { of GDP, } \\
\text { split evenly over first } 15 \text { years }\end{array}$ & $\begin{array}{l}-0.46 \text {, } \\
\text { split evenly over first } 5 \text { years }\end{array}$ & & & \\
\hline China & & $\begin{array}{l}-0.80, \text { split over first } 10 \text { years with } \\
\text { larger reforms in first } 5 \text { years }\end{array}$ & $\begin{array}{l}2 \% \text { of GDP, split evenly } \\
\text { over } 1 \text { st and } 2 \text { nd year }\end{array}$ & $\begin{array}{l}\text { 6.50, split evenly over } \\
\text { first } 10 \text { years }\end{array}$ & \\
\hline $\begin{array}{l}\text { Unweighted average of other } \\
\text { countries in the region }{ }^{1}\end{array}$ & $\begin{array}{c}4.5 \% \text { of GDP, } \\
\text { split evenly over first } 15 \text { years }\end{array}$ & & & & \\
\hline \multicolumn{6}{|l|}{ Euro area scenarios } \\
\hline Germany & $\begin{array}{c}1.3 \% \text { of GDP, } \\
\text { split evenly over first } 15 \text { years }\end{array}$ & $\begin{array}{l}-0.46, \\
\text { split evenly over first } 5 \text { years }\end{array}$ & & & \\
\hline Spain & $\begin{array}{l}\text { 9.6\% of GDP, } \\
\text { split evenly over first } 15 \text { years }\end{array}$ & & & & $\begin{array}{l}-2.41 \text {, } \\
\text { split evenly over first } 5 \text { years }\end{array}$ \\
\hline Portugal & $\begin{array}{c}6.2 \% \text { of GDP, } \\
\text { split evenly over first } 15 \text { years }\end{array}$ & & & & $\begin{array}{l}-2.58, \\
\text { split evenly over first } 5 \text { years }\end{array}$ \\
\hline Greece & $\begin{array}{l}\text { 9.3\% of GDP, } \\
\text { split evenly over first } 15 \text { years }\end{array}$ & & & & $\begin{array}{l}-2.16 \\
\text { split evenly over first } 5 \text { years }\end{array}$ \\
\hline $\begin{array}{l}\text { Unweighted average of other } \\
\text { countries in the region }\end{array}$ & $\begin{array}{c}4.7 \% \text { of GDP, } \\
\text { split evenly over first } 15 \text { years }\end{array}$ & & & & \\
\hline Specifications & Table 1 (SAVT) & Table 3 (INVT) & Table 3 (SAVP) & Table 5 (SAVT) & Table 3 (INVT) \\
\hline
\end{tabular}

1. Australia, Austria, Belgium, Canada, Czech Republic, Denmark, Finland, France, Greece, Hungary, Iceland, Ireland, Italy, Korea, Netherlands, New Zealand, Norway, Poland, Portugal Slovak Republic, Spain, Sweden Switzerland, United Kingdom.

2. Austria, Belgium, Finland, France, Ireland, Italy, Netherlands, Slovak Republic. 
Figure 5. Simulated impact of structural reforms and fiscal consolidation on a summary measure of global and intra-euro-area imbalances

$\%$ of region-wide GDP

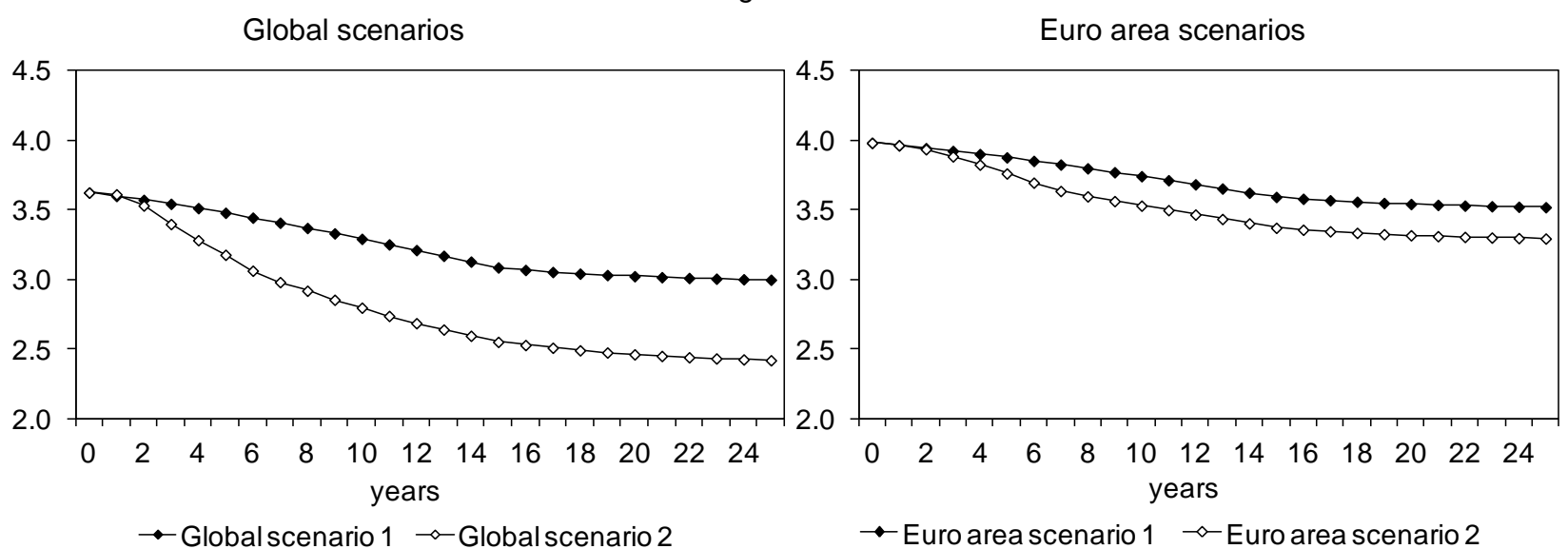

Note: The size of imbalances is measured as the sum of the absolute saving-investment-gap-to-GDP ratios of all countries in the region, weighted by 2009 GDP (in current USD). The starting values are based on the current-account-to-GDP ratios in 2009. Global scenario 1 and Euro area scenario 1 only feature fiscal adjustment, whereas Global scenario 2 and Euro area scenario 2 feature fiscal adjustment and structural reforms.

Source: Simulations based on assumptions presented in Table 7.

37. The removal of competition-unfriendly product market regulation in Japan, Germany, and China would temporarily reduce the saving-investment gaps of all three countries. In the year after the reform is fully phased in, the investment rate of Germany would be 0.4 percentage points above its pre-reform level, whereas those of Japan and China would be 0.15 and 0.2 percentage points higher, respectively. The increase in public health expenditure in China would reduce the country's saving-investment surplus by a further $13 / 4$ percentage points of GDP, with more than half of the adjustment complete after about five years. ${ }^{82}$ The decline in the surplus attributable to structural reforms could reach over 5 percentage points of GDP if China also were to implement financial market reforms. Overall, a combination of fiscal tightening/loosening and structural reforms would reduce global imbalances by about one-third over the forecast horizon, compared with one-sixth in the pure fiscal scenario (Figure 5). Similarly, the structural reforms that underpin the euro area scenario would contribute to a narrowing of intra-euro-area imbalances. While, overall, the size of this effect would be rather modest, saving-investment gaps would be reduced significantly in the smaller euro area countries (Figure 4). ${ }^{83}$ The simulated contribution of structural reforms to the reduction in global and intra-euro area imbalances represents a lower-bound estimate since their indirect impact through changes in macroeconomic conditions is not fully taken into account. ${ }^{84}$ Moreover, it should be kept in mind that the summary measure of imbalances used here implicitly takes zero current accounts as the benchmark. It seems plausible that observed current account imbalances are at least partially an equilibrium phenomenon, so that there would be no need to bring them

82. Relaxing the assumption that the increase in health spending is fiscally neutral would lead to an even larger effect.

83. For instance, when using an unweighted measure of imbalances, the overall decline in intra-euro area imbalances due to fiscal measures and structural policies amounts to almost one-fourth.

84. Also, the simulations do not account for possible structural reforms in the United States that might boost saving and thus lower the size of global imbalances (e.g. a reduction of tax deductibility of interest payments on mortgages), the reason being the lack of empirical estimates of the size of the associated saving effects. 
ECO/WKP(2010)71

fully back to zero. To the extent that this is the case, the share of any undesirable imbalance that could be reduced through structural reforms would be bigger than computed here. ${ }^{85}$

85. If by contrast (at least some) countries' observed and equilibrium current account positions were of opposite signs, the contribution of structural reforms to reducing "undesirable" imbalances would be less than computed here against the zero benchmark. 


\section{REFERENCES}

Abel, A.B. and J.C. Eberly (1994), "A Unified Model of Investment Under Uncertainty", American Economic Review, Vol. 84, pp. 1369-1384.

Abiad, A., E. Detragiache and T. Tressel (2010), “A New Database of Financial Reforms”, IMF Staff Papers, Vol. 57, pp. 281-302.

Aglietta, M. et al. (2007), "Pension Reforms in Europe: An Investigation with a Computable OLG World Model”, Economic Modelling, Vol. 24, pp. 481-505.

Alesina, A., Ardana, S., Perotti, R. and F. Schiantarelli (2002), "Fiscal Policy, Profit and Investment", American Economic Review, Vol. 92, pp. 571-589.

Alesina, A., S. Ardagna, G. Nicoletti, and F. Schiantarelli (2005), "Regulation and Investment", Journal of the European Economic Association, Vol. 3, pp. 1-35.

Attanasio, O.P. and A. Brugiavini (2003), "Social Security and Household Saving", Quarterly Journal of Economics, Vol. 118, pp 1075-1179.

Attanasio, O.P., J. Banks and M. Wakefield (2004), "Effectiveness of Tax Incentives to Boost (Retirement) Saving: Theoretical Motivation and Empirical Evidence", OECD Economic Studies No. 39.

Baldacci, E. et al. (2010), "Public Expenditures on Social Programs and Household Consumption in China", IMF Working Paper No. 10/69.

Bandiera, O. et al. (2000), "Does Financial Reform Raise or Reduce Saving?", Review of Economics and Statistics, Vol.82, No. 2, pp. 239-263.

Barnett, S. and R. Brooks (2010), "China: does Government Health and Education Spending Boost Consumption?", IMF Working Paper No. 10/16.

Bartzsch, N. (2006), "Precautionary Saving and Income Uncertainty in Germany - New Evidence from Microdata", Deutsche Bundesbank Discussion Paper Series 1: Economic Studies No. 44/2006.

Bassanini A. et al. (2010), "Institutional Determinants of Worker Flows: A Cross-Country/Cross-Industry Approach”, OECD Social, Employment and Migration Working Papers No. 107.

Bassanini, A. and D. Venn (2007), “Assessing the Impact of Labour Market Policies on Productivity: a Difference-in-Differences Approach", OECD Social, Employment and Migration Working Papers No. 54.

Beck, N. (2001), "Time-series-cross-section Data: What Have We Learned in the Past Few Years? Annual Review of Political Science, Vol. 4, pp. 271-293. 
Beck. T., A. Demirguc-Kunt, R. Levine and V. Maksimovic (2007), "Financial Structure and Economic Development", World Bank Research Working Paper No. 2423.

Beck, N. and J.N. Katz (2001), "Throwing Out the Baby with the Bath Water: A Comment on Green, Kim, and Yoon”, International Organization, Vol. 55, 487-495.

Benito, A. (2006), “Does Job Insecurity Affect Household Consumption?”, Oxford Economic Papers, Vol. 58, pp 157-181.

Bernanke, B. (2005), "The Global Saving Glut and the US Current Account Deficit”, Sandridge Lecture, Virginia Association of Economics.

Bernanke, B. (2010), "Monetary Policy and the Housing Bubble", Speech at the Annual Meeting of the American Economic Association, Atlanta, Georgia, January 3, 2010.

Boone, L., N. Girouard and I. Wanner (2001), "Financial Liberalization, Wealth and Consumption", OECD Economics Department Working Papers No. 308.

Botero, J. et al. (2004), "The Regulation of Labour”, The Quarterly Journal of Economics, Vol. 119, pp. 1339-1382.

Boulhol, H.A. de Serres and M. Molnar (2008), "The contribution of economic geography to GDP per capita”, OECD Economics Studies, Vol. 2008, pp. 287-323.

Box, S. (2009), "OECD Work on Innovation - A Stocktaking of Existing Work", OECD Science, Technology and Industry Working Papers No. 2009/2.

Bracke, T. et al. (2008), “A Framework for Assessing Global Imbalances”, ECB Occasional Paper Series No. 78.

Caballero, R.J. and A. Krishnamurthy (2009), "Global Imbalances and Financial Fragility", American Economic Review, Vol. 99, pp. 584-588.

Caballero, R.J., E. Farhi and P.-O. Gourinchas (2008), “An Equilibrium Model of 'Global Imbalances' and Low Interest Rates”, American Economic Review, Vol. 98, pp. 358-393.

Caballero, R. J. (2006) “On the macroeconomics of asset shortages”, NBER Working Paper, No. 12753

Carroll D., C., Karen E., D. and K. Spencer (2003), "Unemployment Risk and Precautionary Wealth: Evidence from Households' Balance Sheets", Review of Economic and Statistics, Vol. 85, pp. 586604.

Chamon, M.D. and E.S. Prasad (2010), "Why Are Saving Rates of Urban Households in China Rising?", American Economic Journal: Macroeconomics, Vol. 2, pp. 93-130.

Cheung, C., D. Furceri and E. Rusticelli (2010), "Structural and Cyclical Factors Behind Current-Account Balances", OECD Economics Department Working Papers No. 775.

Chinn, M.D. and H. Ito (2007), "Current Account Balances, Financial Development and Institutions: Assaying the World 'Saving Glut'”, Journal of International Money and Finance, Vol. 26, pp. 546-569. 
Chou, Shin-Yi et al. (2003), "National Health and Precautionary Saving: Evidence from Taiwan", Journal of Public Economics, Vol. 87, pp 1873-1894.

Clark, A. E. and F. Postel-Vinay (2009), "Job Security and Job Protection", Oxford Economic Papers, Vol. 61, pp. 207-239.

Conway, P., D. De Rosa, G. Nicoletti and F. Steiner (2006), "Regulation, Competition and Productivity Convergence", OECD Economics Department Working Papers No. 509.

Corneo, G., M. Keese and C. Schröder (2009), “The Riester Scheme and Private Savings: An Empirical Analysis Based on the German SOEP”, Schmollers Jahrbuch, Vol. 129, pp. 321-332.

Cummins, J., K. Hassett and R. Hubbard (1994), “A Reconsideration of Investment Behaviour Using Tax Reforms as Natural Experiments", Brookings Papers on Economic Activity, Vol. 1994, pp. 1-74.

de Mello, L., P. Kongsrud and R. Price (2004), "Saving Behavior and the Effectiveness of Fiscal Policy", OECD Economics Department Working Papers No. 397.

de Nardi, M., French, E. and J.B. Jones (2006), "Differential Mortality, Uncertain Medical Expenses, and Saving Elderly Singles", NBER Working Paper No. 12554.

de Serres, A. and F. Pelgrin (2003), "The Decline in Private Saving Rates in the 1990s in OECD Countries: How much can be Explained by Non-wealth Determinants? ", OECD Economic Studies, Vol. 36, pp. 117-153.

de Serres, A. et al. (2006), "Regulation of Financial Systems and Economic Growth", OECD Economics Department Working Papers No. 506.

Dewit, G., Görg, H. and C. Montagana (2009), "Should I Stay or Should I Go? Foreign Direct Investment, Employment Protection and Domestic Anchorage", Review of World Economics, Vol. 145, pp. 93-110.

Dixit, R.K. and R.S. Pindyck (1994), Investment Under Uncertainty, Princeton University Press, Princeton.

Dornbusch, R. (1983), "Real Interest Rates, Home Goods and Optimal External Borrowing”, Journal of Political Economy, Vol. 91, pp. 141-53.

Dorrucci, E., Meyer-Cirkel, A. and D. Santabárbara (2009), "Domestic Financial Development in Emerging Economies Evidence and Implications”, ECB Occasional Paper No. 102.

Duval, R. (2003), "The Retirement Effects of Old-Age Pension and Early Retirement Schemes in OECD Countries", OECD Economics Department Working Papers No. 370.

Engen, E. and J. Gruber (2001), "Unemployment Insurance and Precautionary Saving", Journal of Monetary Economics, Vol. 47, pp. 545-579.

Feng, J., L. He and H. Sato (2009), "Public Pension and Household Saving: Evidence from China", Bank of Finland Discussion Papers No. 2/2009.

Ferrucci, G. and C. Miralles (2007), "Saving Behavior and Global Imbalances - the Role of Emerging Market Economies”, ECB Working Papers No. 842. 
Fogli, A. and F. Perri, (2006), "The "Great Moderation" and the US External Imbalance", NBER Working Papers No. 12708.

Fournier, J.-M. and I. Koske (2010), “A Simple Model of the Relationship between Productivity, Saving and the Current Account", OECD Economics Department Working Paper No. 816.

Friedman, M. (1957), A Theory of the Consumption Function, Princeton University Press, Princeton.

Furceri, D. and A. Mourougane (2010), "The Influence of the Age Structure on Saving and Social Spending", mimeo.

Görg, H. (2005), "Fancy a Stay at the "Hotel California"? The Role of Easy Entry and Exit for FDI", Kyklos, Vol. 58, pp. 519-535.

Griffith, R. and R. Harrison (2004), "The Link Between Product Market Reform and Macro-Economic Performance”, European Commission Economic Paper No. 209.

Gruber, J.W. and S.B. Kamin (2007), "Explaining the Global Pattern of Current Account Imbalances", Journal of International Money and Finance, Vol. 26, pp. 500-522.

Gruber, J. and A. Yellowitz (1999), "Public Health Insurance and Savings", Journal of Political Economy, Vol. 107, pp. 1249-1274.

Guariglia, A. and M. Rossi (2002), "Consumption, Habit Formation, and Precautionary Saving: Evidence from the British Household Panel Survey", Oxford Economic Papers, Vol. 54, pp. 1-19.

Haaland, J.I., I. Wooton and G. Faggio (2003), “Multinational Firms: Easy Come, Easy Go?" FinanzArchiv, Vol. 59, pp. 3-26.

Hall, R.E. and D. Jorgenson (1967), “Tax Policy and Investment Behaviour”, American Economic Review, Vol. 57, pp. 391-414.

Harris, M.N., Loundes, J. and E. Webster (2002), "Determinants of Household Saving in Australia", Economic Record, Vol. 78, pp. 207-223.

Hassett, K. and R. Hubbard (2002), "Tax Policy and Business Investment, in Auerbach”, A.J. and M. Feldstein (eds.), Handbook of Public Economics, Vol. 3, Elsevier, North-Holland.

Hausmann, R. and F. Sturzenegger (2005), "U.S. and global imbalances: Can dark matter prevent a big bang?" Center for International Development Working Paper, Harvard University, Cambridge.

Henry, P.B. (1999), “Do Stock Market Liberalizations Cause Investment Booms?”, Journal of Financial Economics, Vol. 58, pp. 301-334.

Hubbard, G.R. et al. (1995), "Precautionary Saving and Social Insurance", Journal of Political Economy, Vol. 103, pp. 360-399.

Hüfner, F. and I. Koske (2010), "Explaining Household Saving Rates in G7 Countries: Implications for Germany”, OECD Economics Department Working Papers No. 754.

Hurst, E. and J.P. Ziliak (2006), "Do Welfare Asset Limits Affects Household Saving? Evidence from Welfare Reform", Journal of Human Resources, Vol. 41, pp. 46-71. 
Hurst, E., A. Lusardi, A. Kennickel and F. Torralba (2005), "Precautionary Savings and the Importance Business Owners", NBER Working Paper No. 11731.

Jappelli, T. et al. (2006), "Health Care Quality, Economic Inequality, and Precautionary Saving", Health Economics, Vol. 16, pp. 327-346.

Javorcik, B. S. and M. Spatareanu (2005). "Do Foreign Investors Care About Labor Market Regulations?" Review of World Economics, Vol. 127, pp. 375-403.

Jeanne, O. and R. Ranciere (2008), "The Optimal Level of International Reserves for Emerging Market Countries: A New Formula and Some Applications", CEPR Discussion Paper No. 723.

Jha, S., E. Prasad and A. Terada-Hagiwra (2009), "Saving in Asia and Issues for Rebalancing Growth", ADB Economics Working Paper Series No. 161.

Jorgenson, D. (1963), “Capital Theory and Investment Behavior”, American Economic Review, Vol. 53, pp. 247-259.

Ju, J. and S.-J. Wei (2006), “A Solution to Two Paradoxes of International Capital Flows", NBER Working Paper No. 12668.

Kennedy, M. and T. Sløk (2005), "Structural Policy Reforms and External Imbalances", OECD Economics Department Working Papers No. 415.

Kirsanova, T. and J. Sefton (2007), "A Comparison of National Saving Rates in the UK, US and Italy", European Economic Review, Vol. 51, pp. 1998-2028.

Koskela, E. and M. Viren (1994), "Taxation and Households Saving in Open Economies-Evidence From the Nordic Countries", Scandinavian Journal of Economics, Vol. 96, pp. 425-445.

Krugman, P. (1989), "Differences in Income Elasticities and Trends in Real Exchange Rates", European Economic Review, Vol. 33, pp. 1031-1046.

Levine, R. (2005), "Finance and Growth: Theory, Evidence, and Mechanisms", in: Aghion, P. and S. Durlauf (eds.), The Handbook of Economic Growth, North-Holland, Amsterdam.

Loayza, N., K. Schmidt-Hebbel and L. Serven (2000), "What Drives Private Saving Across the World?", Review of Economics and Statistics, Vol. 82, pp. 165-181.

Lusardi, A. (1997), "Precautionary Saving and Subjective Earnings Variance", Economics Letters, Vol. 57, pp. 319-326.

Maynard, A and J. Qiu (2009), "Public Insurance and Private Savings; Who is Affected and by How Much?", Journal of Applied Econometrics, Vol. 24, pp. 282-308.

McKernan, S.-M., Ratcliffe, C. and Y. Nam (2007), "The Effects of Welfare and IDA Program Rules on the Asset Holdings of Low-Income Families", US Department of Health and Human Services, United States.

Modigliani, F. (1966), "The Life-Cycle Hypothesis of Saving, the Demand of Wealth and the Supply of Capital”, Social Research, Vol. 33, pp. 55-84. 
Modigliani, F. and A. Ando (1963): "The Life Cycle Hypothesis of Saving: Aggregated Implications and Tests". American Economic Review, Vol. 53, pp. 55-84.

Nam, Y. (2008), "Welfare Reform, Asset Limits, and Financial Asset Accumulation Among Low-Income Households", Social Science Quarterly, Vol. 89, pp. 133-154.

Nickell, S. (1981), "Biases in Dynamic Models with Fixed Effects", Econometrica, Vol. 49, pp. 1417-1426.

Nicoletti, G. and S. Scarpetta (2003), "Regulation, Productivity, and Growth: OECD Evidence", World Bank Policy Research Working Paper No. 2944.

Nicoletti, G. et al. (2003), "Policies and International Integration: Influences on Trade and Foreign Direct Investment”, OECD Economics Department Working Paper No. 359.

Obstfeld, M. and Rogoff, K. (2009), "Global Imbalance and Financial Crisis: Products of Common Causes”, Federal Reserve Bank of Asia Economic Policy Conference, Asia.

Obstfeld, M. (2010), “The Immoderate World Economy”, Journal of International Money and Finance, Vol. 29, pp. 603-614.

OECD (2003a), Policy Settings, Institutions and Aggregate Economic Growth: a Cross-Country Analysis, OECD, Paris.

OECD (2003b), ICT and Economic Growth: Evidence from OECD Countries, Industries and Firms, OECD, Paris.

OECD (2007), OECD Tax Policy Studies No. 15: Encouraging Savings through Tax-Preferred Account, OECD, Paris.

OECD (2009), OECD Economic Outlook, Interim Report March 2009, OECD, Paris.

OECD (2010a), OECD Economic Outlook No. 87, OECD, Paris.

OECD (2010b), "The Role of Structural Policies in Housing Markets", paper presented to Working Party No. 1 of the Economic Policy Committee, autumn 2010.

OECD (2010c), OECD Economic Surveys: China, OECD, Paris.

Ostry, J.D. and C.M. Reinhart (1991), "Private Saving and Terms of Trade Shocks: Evidence from Developing Countries", IMF Working Paper No. 91/100.

Papaioannou, E. (2007), "Finance and Growth with a Macroeconomic Assessment of the Evidence from a European Angle", ECB Working Paper No. 787.

Plümper, T. and V. Troeger (2007), "Efficient Estimation of Time-Invariant and Rarely Changing Variables in Finite Sample Panel Analyses with Unit Fixed Effects", Political Analysis, Vol. 15, pp. 124-139.

Poterba, J., S. Venti and D. Wise (1996), "How Retirement Saving Programs Increase Saving", Journal of Economic Perspectives, Vol. 10, pp. 91-112. 
Röhn, O. (2010), "New Evidence on the Private Saving Offset and Ricardian Equivalence", OECD Economics Department Working Papers No. 762.

Rossi, M. (2009), "Examining the Interaction Between Saving and Contributions to Personal Pension Plans: Evidence from the BHPS", Oxford Bulletin of Economics and Statistics, Vol. 71, pp. 253-271.

Samwick, A.A. (2000), "Is Pension Reform Conducive to Higher Saving?", The Review of Economics and Statistics, Vol. 82, pp. 264-272.

Sarantis, N. and C. Stewart (2001), "Saving behaviour in OECD countries: Evidence from Panel Cointegration Tests", The Manchester School, Vol. 69, pp. 22-41.

Scarpetta, S. and T. Tressel (2002), "Productivity and Convergence in a Panel of OECD Industries: Do Regulations and Institutions Matter?”, OECD Economics Department Working Papers No. 342.

Scarpetta, S. and T. Tressel (2004), "Boosting Productivity via Innovation and Adoption of New Technologies: Any Role for Labor Market Institutions?”, World Bank Policy Research Working Paper Series No. 3273.

Schiantarelli, F. (2008), "Product Market Regulation and Macroeconomic Performance: a Review of Cross-Country Evidence", Boston College Working Papers in Economics No. 623.

Schwellnus, C. and J.M. Arnold (2008), "Do Corporate Taxes Reduce Productivity and Investment at the Firm Level? Cross-Country Evidence From the Amadeus Dataset", OECD Economics Department Working Papers No. 641.

Sullivan, X.J. (2006), "Welfare Reform, Saving, and Vehicle Ownership”, Journal of Human Resources, Vol. 41, pp. 72-105.

Summers, H.L. (1984), "The After Tax of Return Affects Private Savings", NBER Working Paper No. 1351.

Vartia, L. (2008), "How do Taxes Affect Investment and Productivity? An industry-level analysis of OECD countries", OECD Economics Department Working Papers No. 656.

Zhou (2003), "Precautionary Saving and Earnings Uncertainty in Japan: A Household-Level Analysis", Journal of the Japanese and International Economies, Vol. 17, pp. 192-212. 
ANNEX 1. ADDITIONAL FIGURES AND TABLES

Figure A1.1. In-sample and out-of sample forecasting properties of baseline saving rate specifications - selected OECD countries
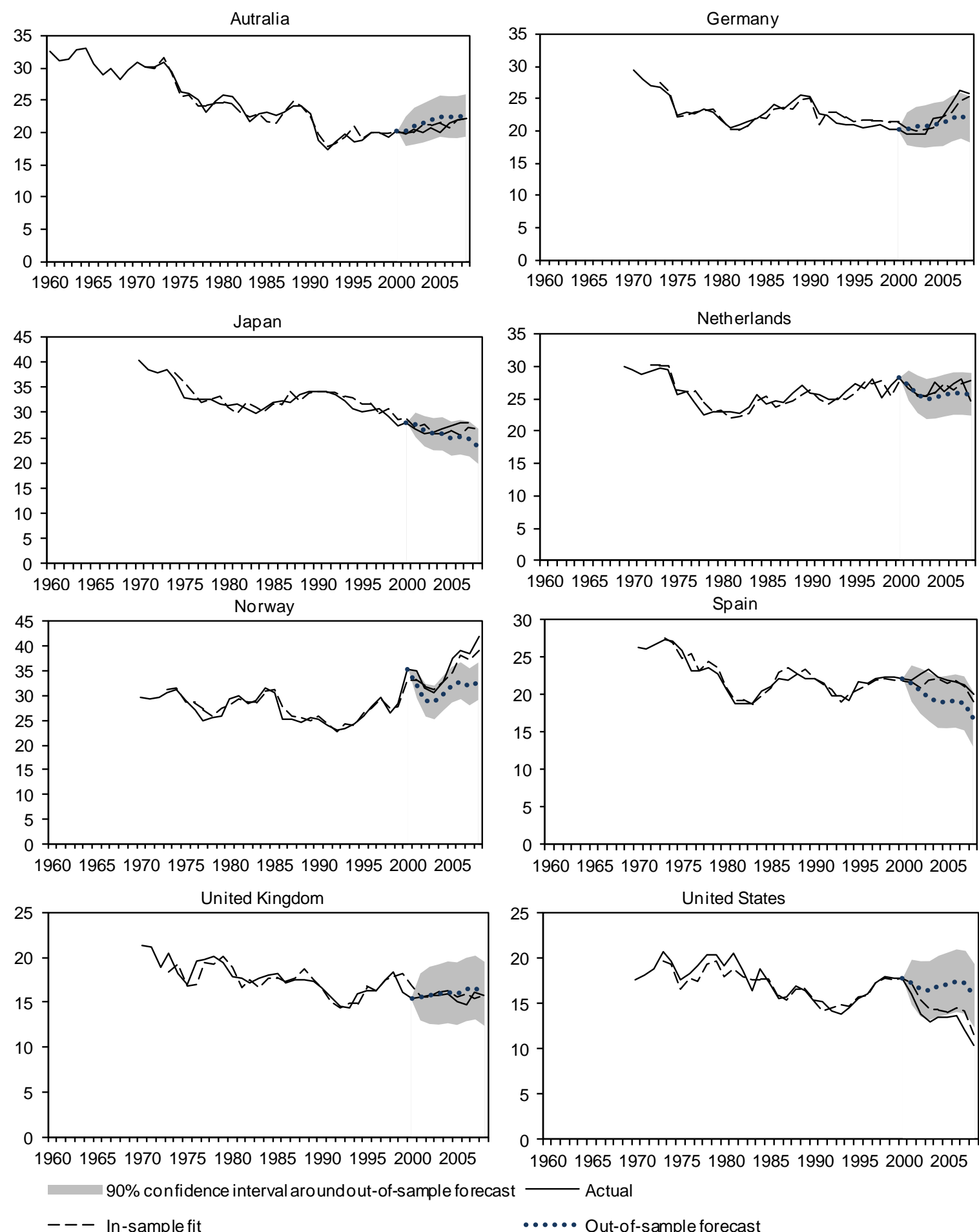

Note: The in-sample fit is the total saving rate implied by the baseline specification with country and period fixed effects, estimated over the entire sample period. The out-of-sample forecast is the dynamic forecast of the total saving rate based on the baseline specification estimated until the year 2000 . 
Figure A1.2. In-sample and out-of sample forecasting properties of baseline investment rate specifications - selected OECD countries

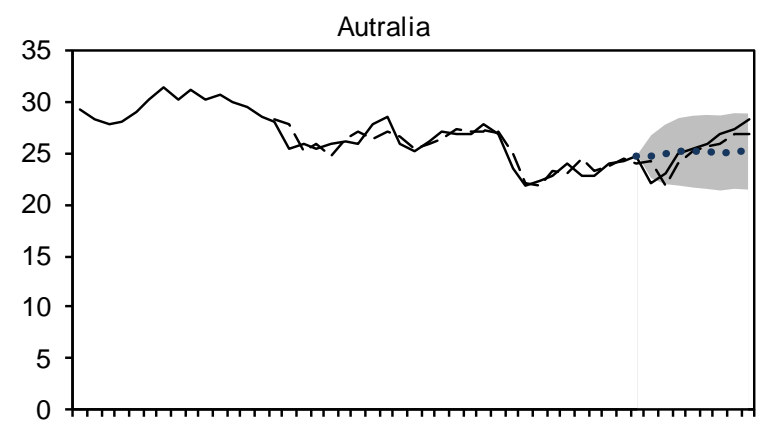

1960196519701975198019851990199520002005

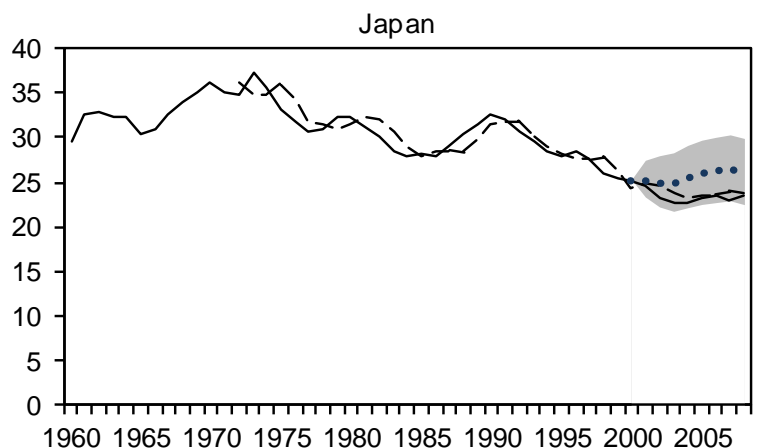

1960196519701975198019851990199520002005
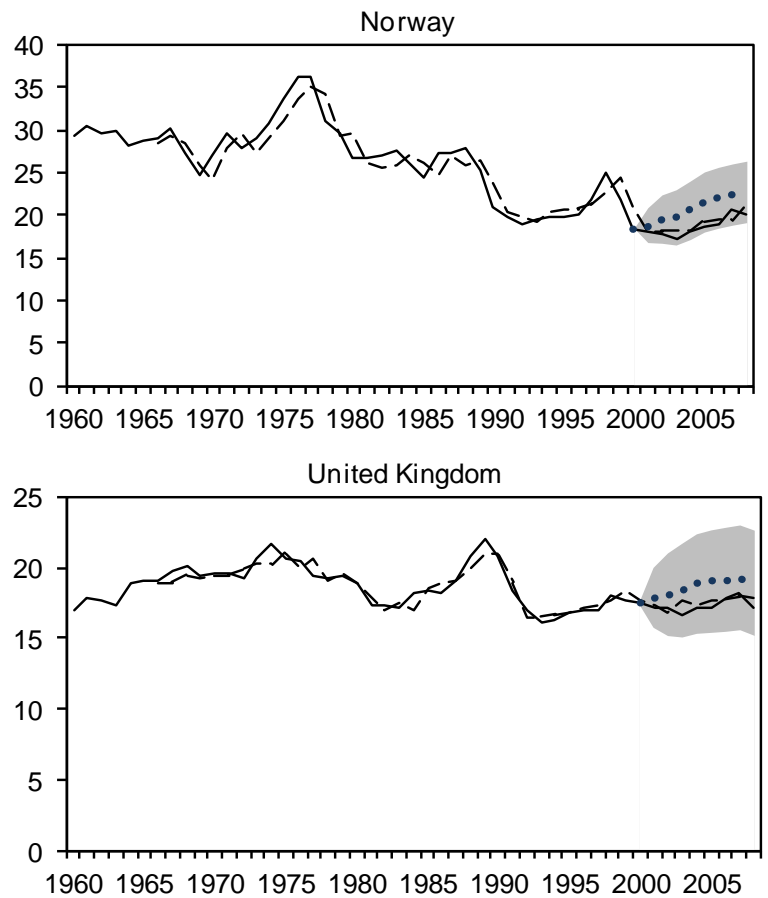
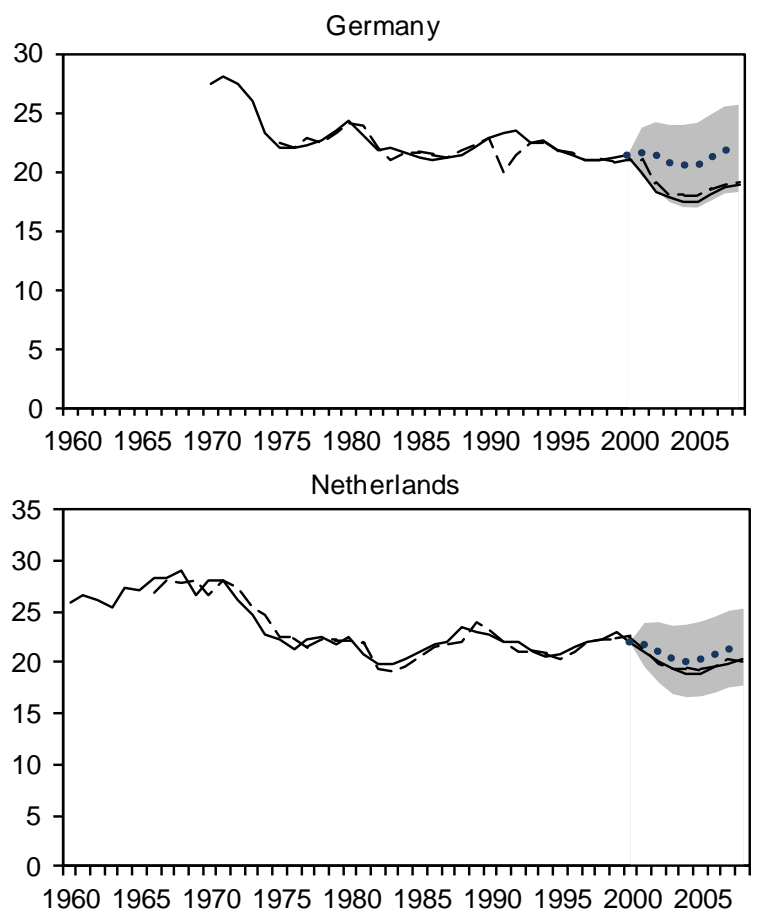

Spain
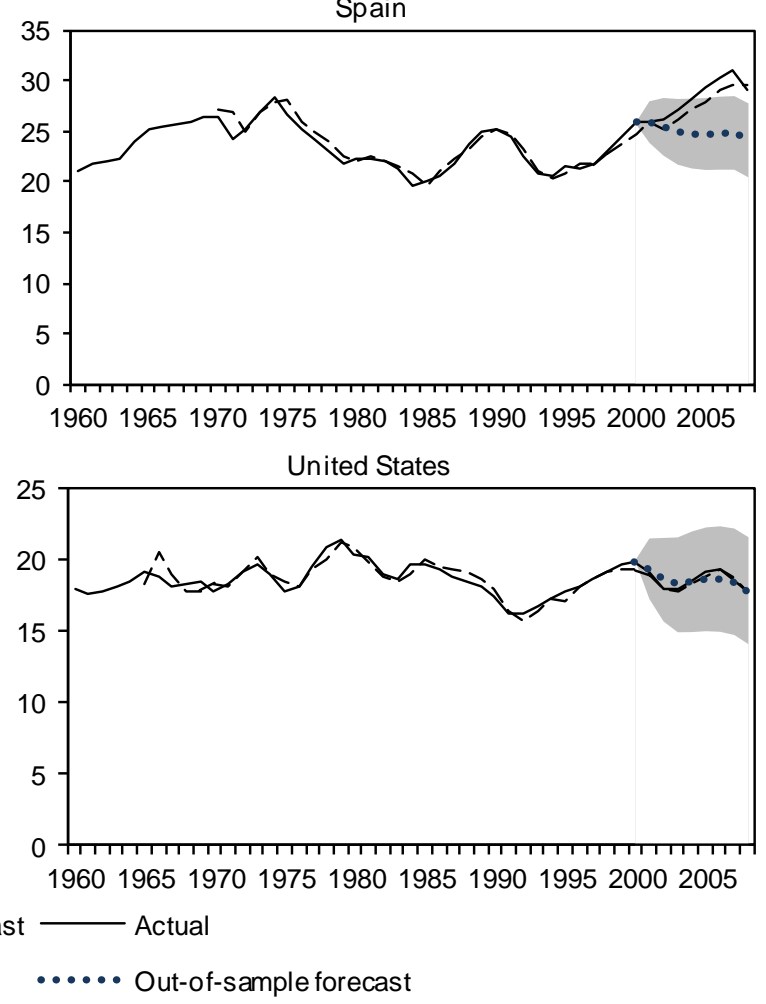

Note: The in-sample fit is the total investment rate implied by the baseline specification with country and period fixed effects, estimated over the entire sample period. The out-of-sample forecast is the dynamic forecast of the total investment rate based on the baseline specification estimated until the year 2000 . 
Figure A1.3. Robustness of estimation results to variations in the set of countries included in the sample - total saving rate
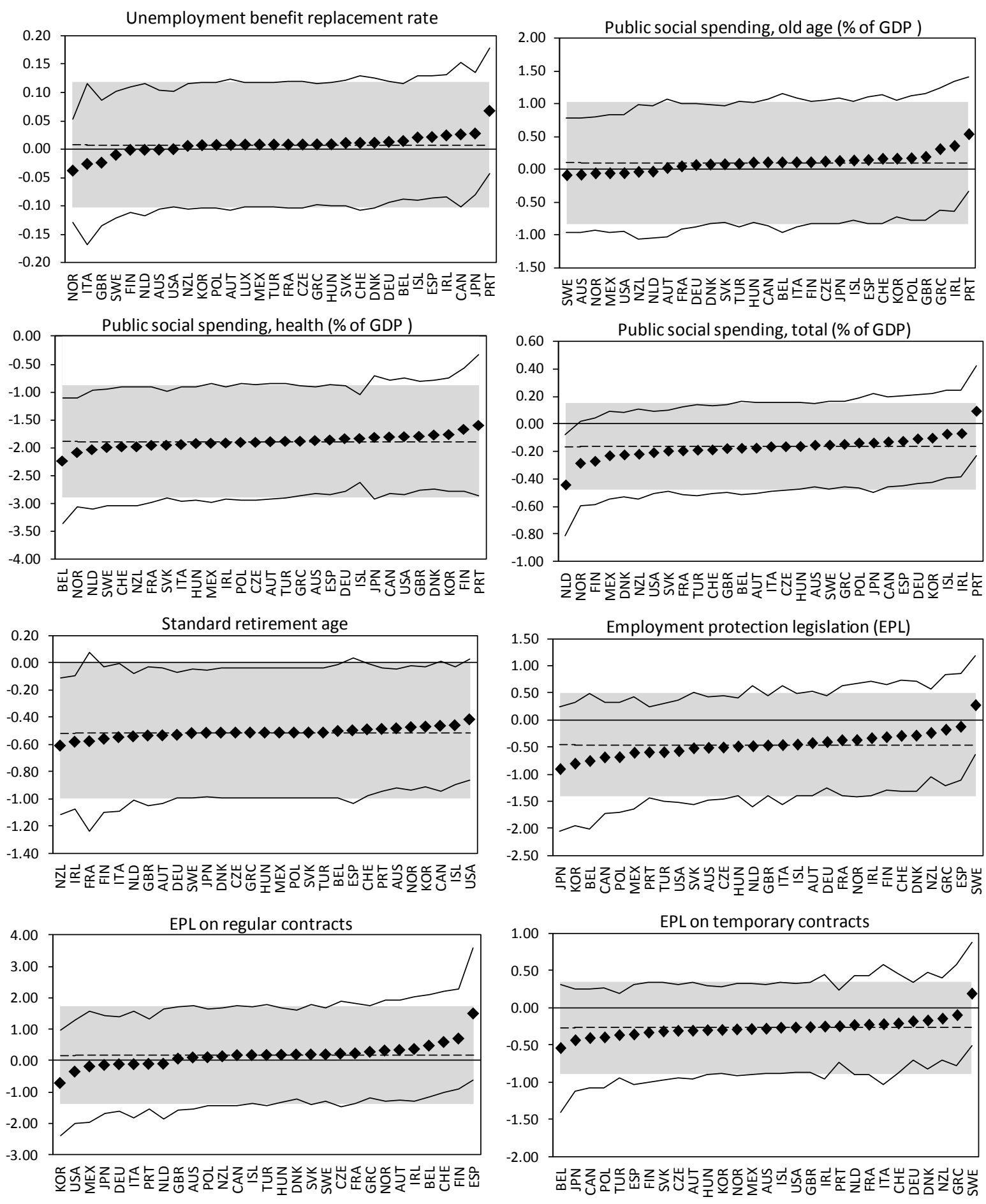
Figure A1.3. Robustness of estimation results to variations in the set of countries included in the sample - total saving rate (cont.)
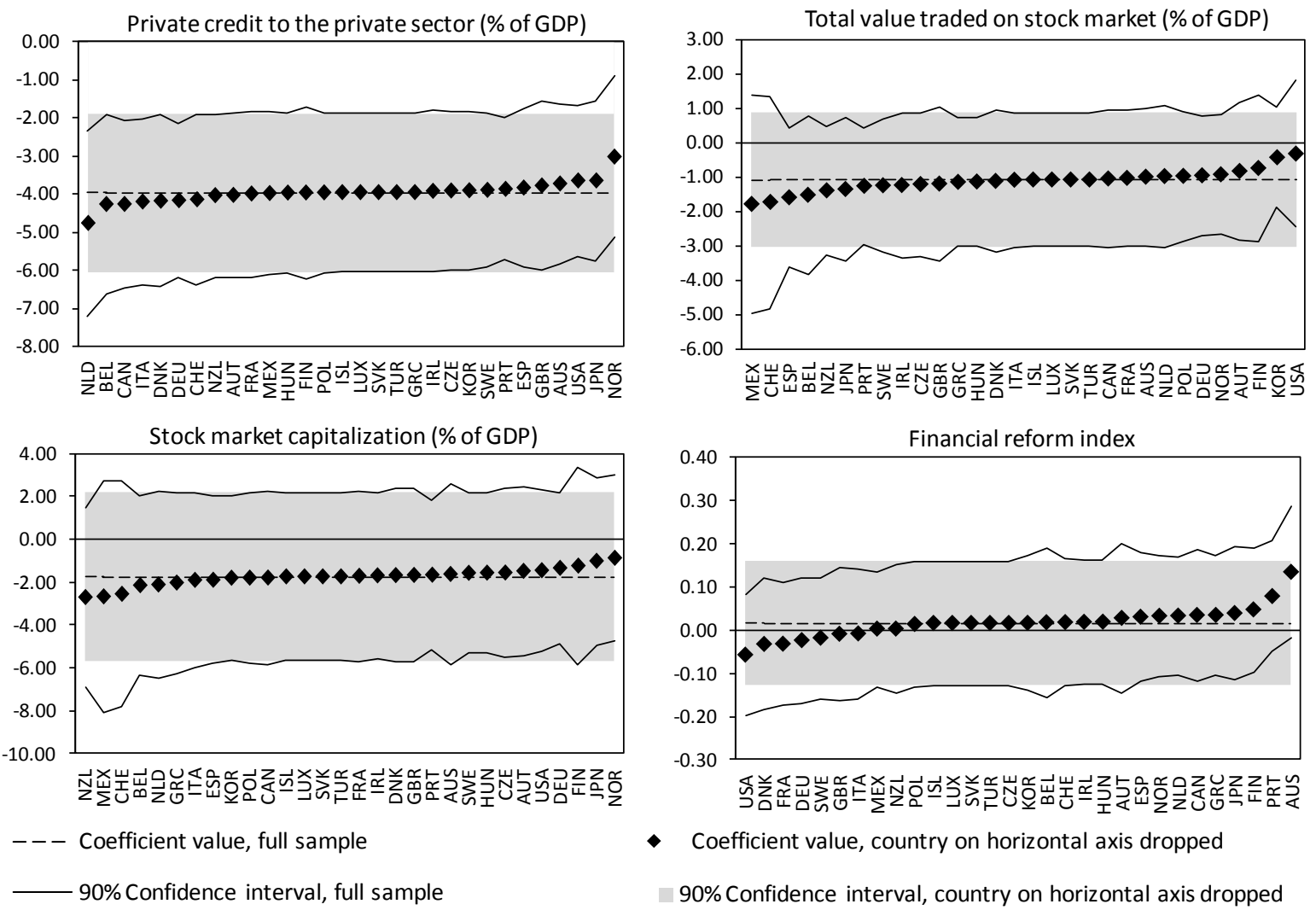

- Coefficient value, country on horizontal axis dropped

$90 \%$ Confidence interval, country on horizontal axis dropped

Figure A1.4. Robustness of estimation results to variations in the set of countries included in the sample - private saving rate (SAVP)
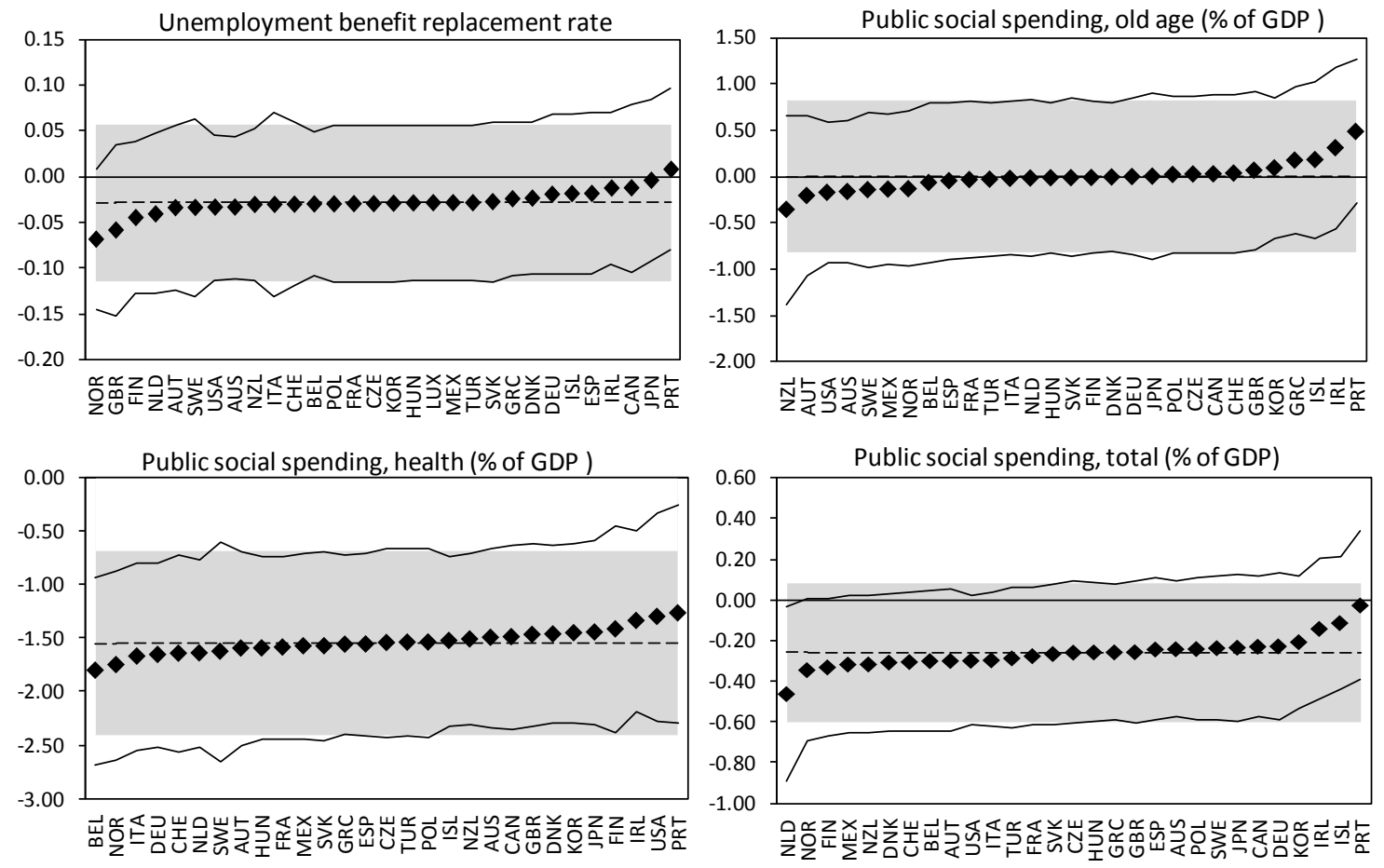
Figure A1.4. Robustness of estimation results to variations in the set of countries included in the sample - private saving rate (cont.)
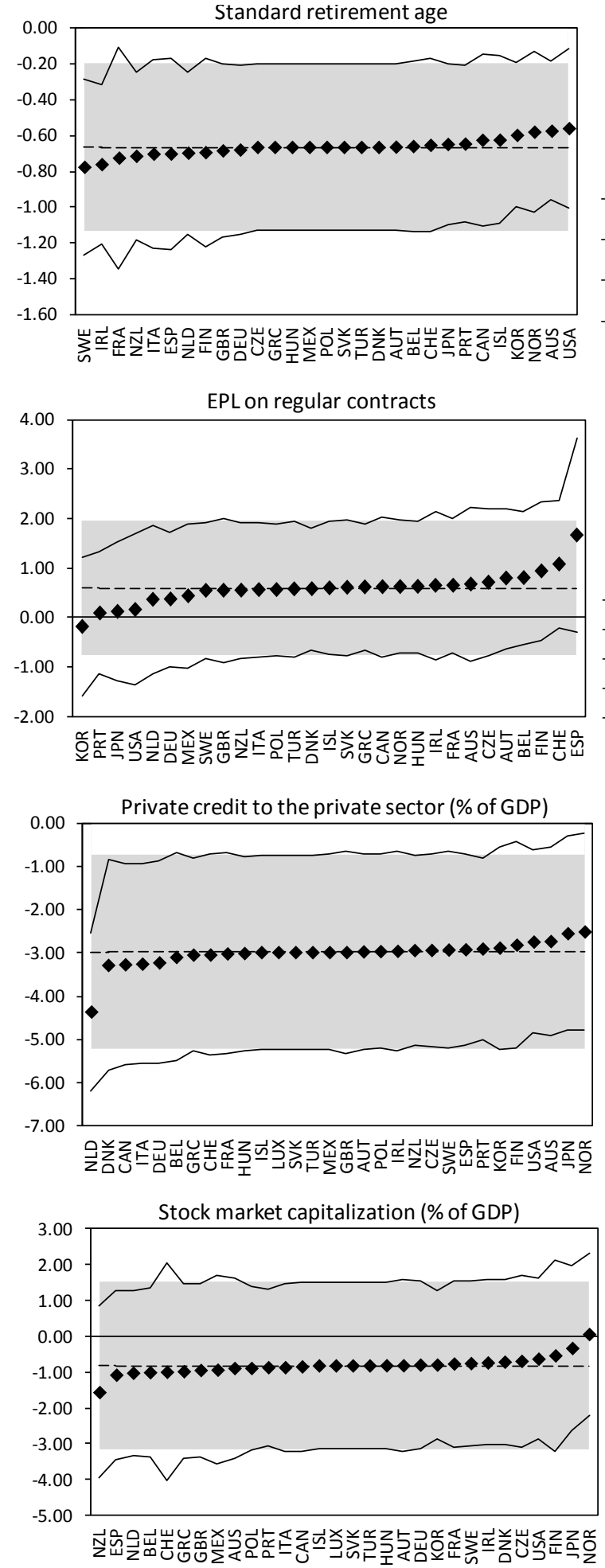

--- Coefficient value, full sample

— $90 \%$ Confidence interval, full sample
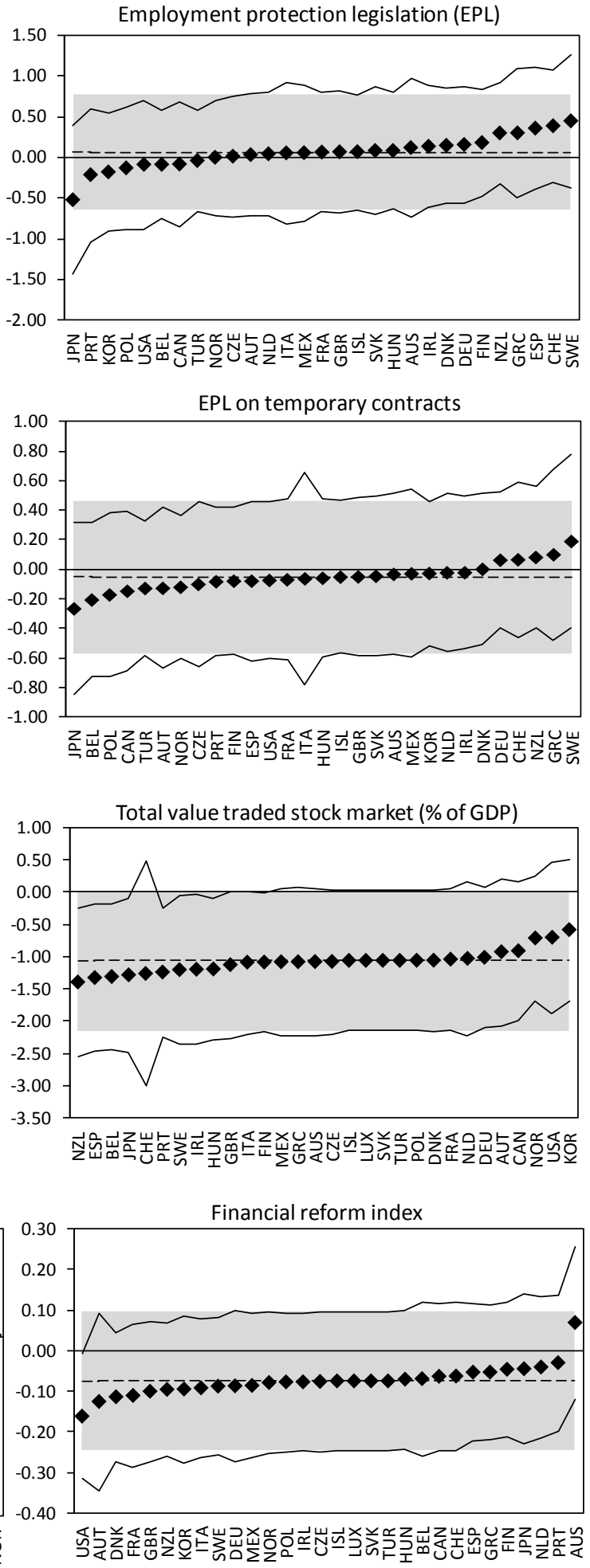

- Coefficient value, country on horizontal axis dropped

90\% Confidence interval, country on horizontal axis dropped 
Figure A1.5. Robustness of estimation results to variations in the set of countries included in the sample - total investment rate
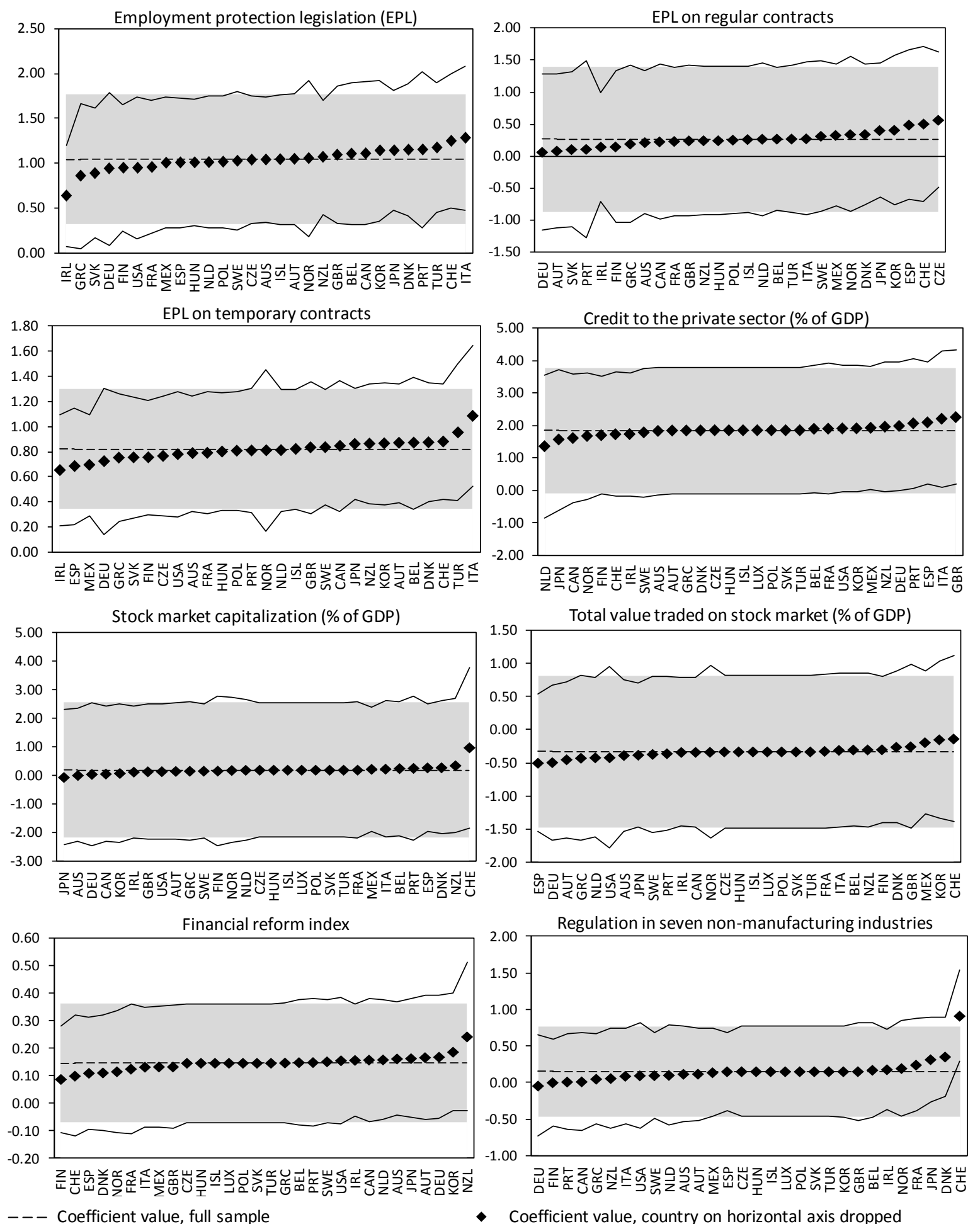

-- Coefficient value, full sample

- Coefficient value, country on horizontal axis dropped

- $90 \%$ Confidence interval, full sample

90\% Confidence interval, country on horizontal axis dropped 
Figure A1.6. Robustness of estimation results to variations in the set of countries included in the sample - private investment rate
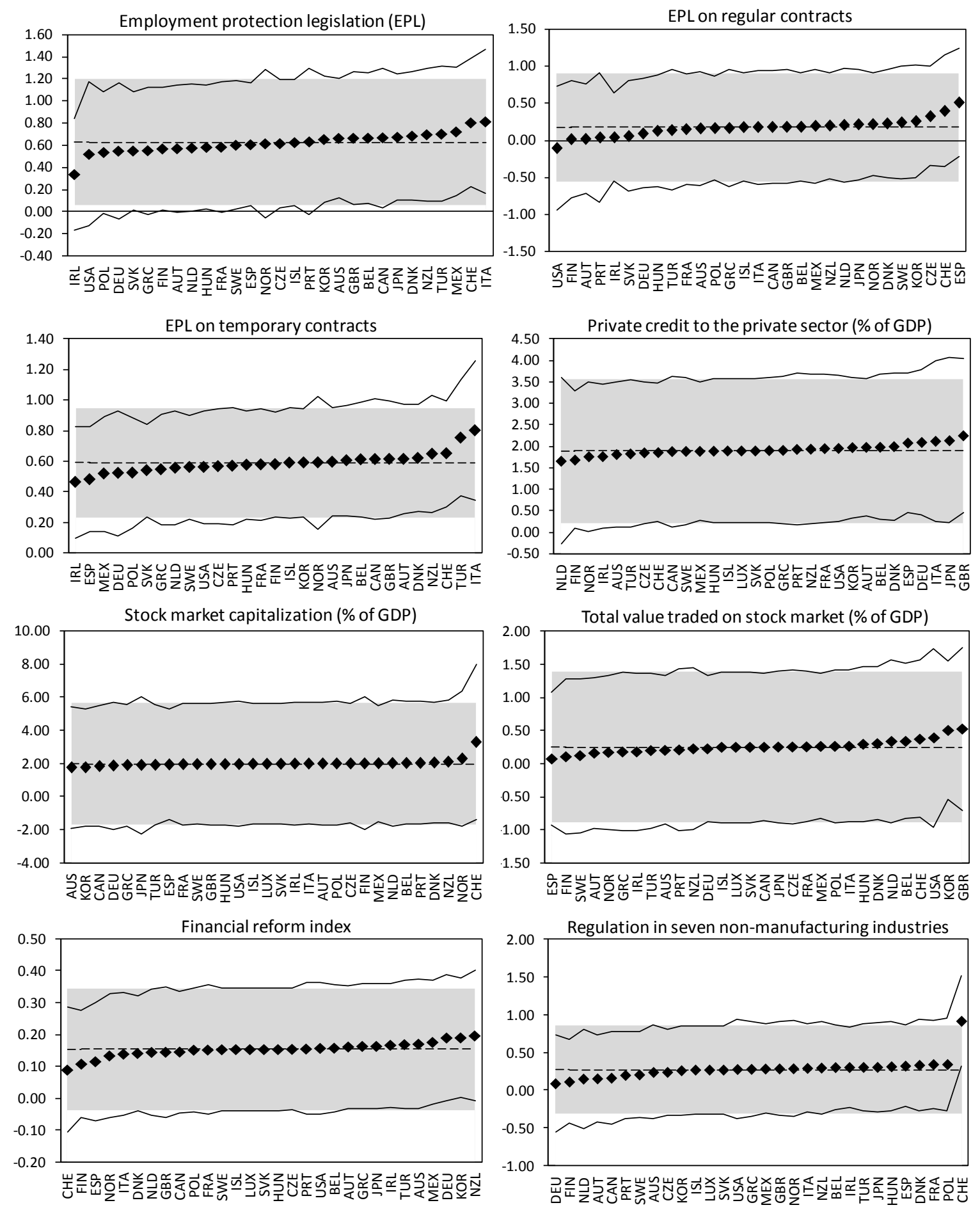

- - - Coefficient value, full sample

- Coefficient value, country on horizontal axis dropped

_ $90 \%$ Confidence interval, full sample

$90 \%$ Confidence interval, country on horizontal axis dropped 
Figure A1.7. Estimated adjustment of saving and investment rates to selected structural reforms Total saving rate

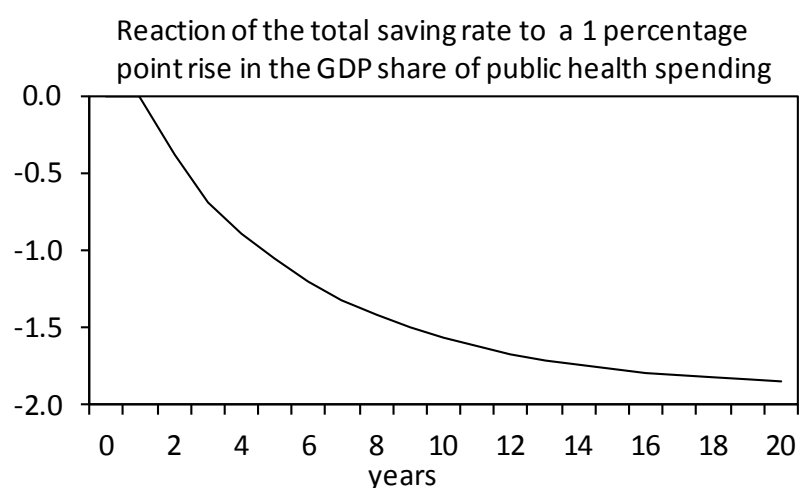

Reaction of the total saving rate to a rise in the

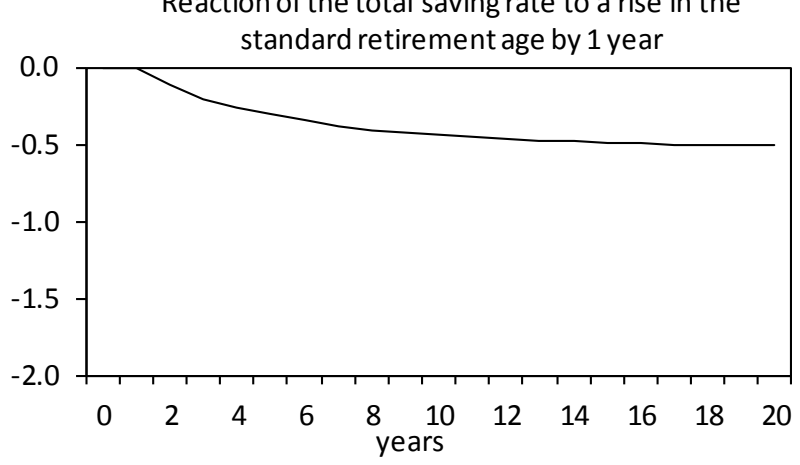

Reaction of the total saving rate to a 1 percentage point rise in the GDP share of private credit

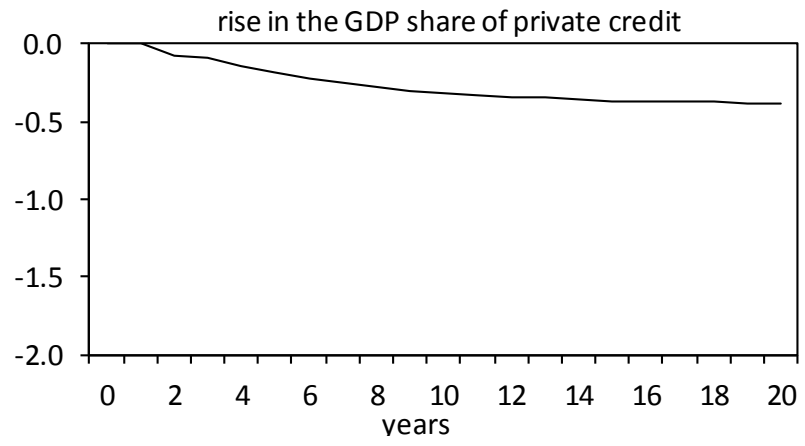

Total investment rate
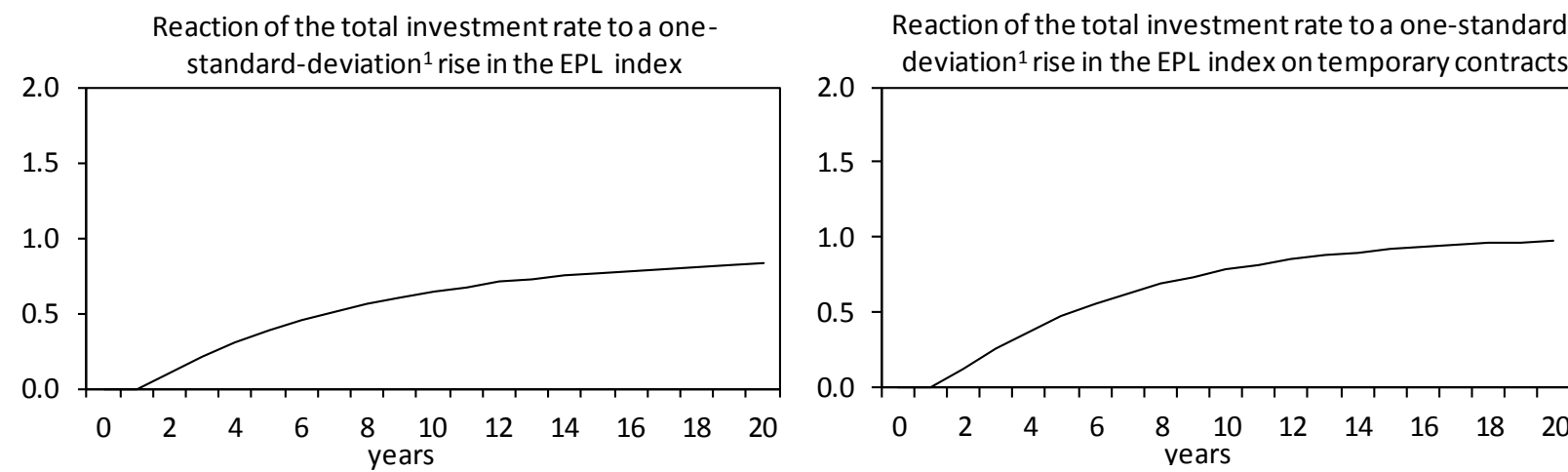

Reaction of the total investment rate to a one-standard-

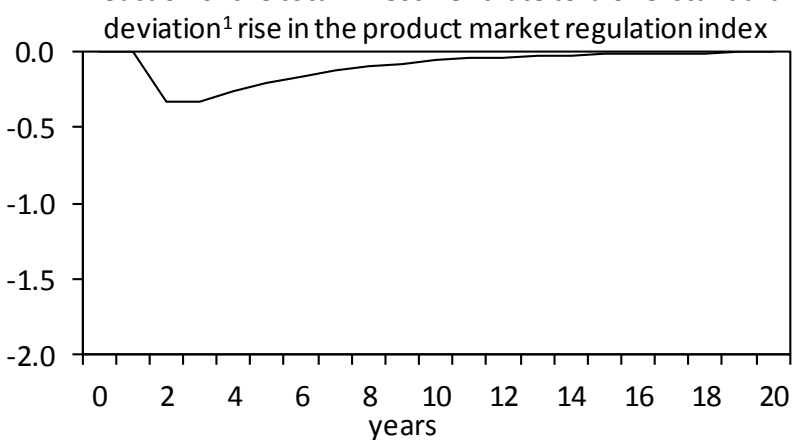

1. Standard deviation across all OECD countries in 2008 for EPL and in 2007 for product market regulation.

Source: Simulations based on coefficient estimates presented in Table 3. 
ECO/WKP(2010)71

Table A1.1. Data definition and sources - OECD dataset

\begin{tabular}{|c|c|c|}
\hline Variable & Definition & Source \\
\hline Total saving rate & Gross national saving, $\%$ of GDP & $\begin{array}{l}\text { World Development Indicators, Annual } \\
\text { National Accounts Database }\end{array}$ \\
\hline Private saving rate & $\begin{array}{l}\text { Difference between gross total saving and } \\
\text { gross government saving, \% of GDP }\end{array}$ & $\begin{array}{l}\text { World Development Indicators, Annual } \\
\text { National Accounts Database, } \\
\text { Analytical Database }\end{array}$ \\
\hline Total investment rate & Gross fixed capital formation, \% of GDP & $\begin{array}{l}\text { World Development Indicators, Annual } \\
\text { National Accounts Database }\end{array}$ \\
\hline Private investment rate & $\begin{array}{l}\text { Difference between gross fixed capital } \\
\text { formation and gross government fixed capital } \\
\text { formation, \% of GDP }\end{array}$ & Analytical Database \\
\hline Current account balance & $\%$ of GDP & World Development Indicators \\
\hline Government net lending & $\%$ of GDP & Analytical Database \\
\hline Real long-term interest rate & $\begin{array}{l}\text { Long-term interest rate on government bonds, } \\
\text { CPI deflated, \% }\end{array}$ & $\begin{array}{l}\text { Analytical Database, International } \\
\text { Financial Statistics Database }\end{array}$ \\
\hline Old-age dependency ratio & $\begin{array}{l}\text { Ratio of population older than } 64 \text { years to } \\
\text { population aged } 15 \text { to } 64\end{array}$ & World Development Indicators \\
\hline Youth dependency ratio & $\begin{array}{l}\text { Ratio of population younger than } 15 \text { years to } \\
\text { population aged } 15 \text { to } 64\end{array}$ & World Development Indicators \\
\hline Productivity & Real GDP (2005 PPP USD) per worker & Analytical Database \\
\hline Terms of trade & Goods and services, index & Analytical Database \\
\hline User cost of capital & $\begin{array}{l}\left(P I T_{t} / P G D P_{t}\right)^{*}\left(I R L_{t}+R S C R_{t}-\right. \\
\left.\left(P I T_{t}-P I T_{t-1}\right) / P I T_{t-1}\right), \text { where } P I T \text { denotes the } \\
\text { gross fixed capital formation deflator, } P G D P \text { the } \\
\text { GDP deflator, IRL the long-term real interest } \\
\text { rate and } R S C R \text { the total economy capital stock } \\
\text { scrapping rate }\end{array}$ & Analytical Database \\
\hline Population aged 15 to 64 & Thousands & World Development Indicators \\
\hline $\begin{array}{l}\text { Unemployment benefit } \\
\text { replacement rate }\end{array}$ & $\begin{array}{l}\text { Average of the gross unemployment benefit } \\
\text { replacement rate for two earnings levels, three } \\
\text { family situations and three durations of } \\
\text { unemployment }\end{array}$ & Benefits and Wages Database \\
\hline Public social spending, old age & $\%$ of GDP & Social Expenditure Database \\
\hline Public social spending, health & $\%$ of GDP & Social Expenditure Database \\
\hline Public social spending, total & $\%$ of GDP & Social Expenditure Database \\
\hline Standard retirement age & Average of women and men & Duval (2003) \\
\hline $\begin{array}{l}\text { Employment protection } \\
\text { legislation }\end{array}$ & $\begin{array}{l}\text { Index from } 0 \text { to } 6 \text { from lowest to highest } \\
\text { protection }\end{array}$ & $\begin{array}{l}\text { Employment Protection Legislation } \\
\text { Database }\end{array}$ \\
\hline $\begin{array}{l}\text { Sub-indicator for dismissal of } \\
\text { employees on regular contracts }\end{array}$ & $\begin{array}{l}\text { Index from } 0 \text { to } 6 \text { from lowest to highest } \\
\text { protection }\end{array}$ & $\begin{array}{l}\text { Employment Protection Legislation } \\
\text { Database }\end{array}$ \\
\hline $\begin{array}{l}\text { Sub-indicator for regulation on } \\
\text { temporary contracts }\end{array}$ & $\begin{array}{l}\text { Index from } 0 \text { to } 6 \text { from lowest to highest } \\
\text { protection }\end{array}$ & $\begin{array}{l}\text { Employment Protection Legislation } \\
\text { Database }\end{array}$ \\
\hline Credit to the private sector & $\begin{array}{l}\text { Private credit by deposit money banks \& other } \\
\text { financial institutions, } \% \text { of GDP }\end{array}$ & $\begin{array}{l}\text { Beck et al. (2007) and International } \\
\text { Financial Statistics Database }\end{array}$ \\
\hline $\begin{array}{l}\text { Total value traded on the stock } \\
\text { market }\end{array}$ & $\%$ of GDP & $\begin{array}{l}\text { World Bank Database on Financial } \\
\text { Development and Structure }\end{array}$ \\
\hline Stock market capitalization & $\%$ of GDP & $\begin{array}{l}\text { World Bank Database on Financial } \\
\text { Development and Structure }\end{array}$ \\
\hline Financial reform index & Index from 0 to 21 from least to most developed & Abiad et al. (2010) \\
\hline $\begin{array}{l}\text { Regulation in seven non- } \\
\text { manufacturing sectors }\end{array}$ & $\begin{array}{l}\text { Airlines, telecoms, electricity, gas, post, rail, } \\
\text { road freight, index from } 0 \text { to } 6 \text { from least to } \\
\text { most restrictive }\end{array}$ & $\begin{array}{l}\text { International Product Market } \\
\text { Regulation Database }\end{array}$ \\
\hline
\end{tabular}


Table A1.2. Data definition and sources - OECD/non-OECD dataset

\begin{tabular}{|c|c|c|}
\hline Variable & & Source \\
\hline Total saving rate & Gross national saving, \% of GDP & World Development Indicators. \\
\hline Total investment rate & $\begin{array}{l}\text { Gross fixed capital formation, \% of } \\
\text { GDP }\end{array}$ & World Development Indicators. \\
\hline Current account balance & $\%$ of GDP & World Development Indicators \\
\hline Real interest rate & Discount rate, CPI deflated, \% & $\begin{array}{l}\text { International Financial Statistics } \\
\text { Database }\end{array}$ \\
\hline Old-age dependency ratio & $\begin{array}{l}\text { Ratio of population older than } 64 \\
\text { years to population aged } 15 \text { to } 64\end{array}$ & World Development Indicators \\
\hline Youth dependency ratio & $\begin{array}{l}\text { Ratio of population younger than } \\
15 \text { years to population aged } 15 \text { to } \\
64\end{array}$ & World Development Indicators \\
\hline Productivity & $\begin{array}{l}\text { Real GDP (2005 PPP USD) per } \\
\text { worker }\end{array}$ & World Development Indicators \\
\hline Terms of trade & Goods and services, index & $\begin{array}{l}\text { World Development Indicators, } \\
\text { Analytical Database }\end{array}$ \\
\hline Population aged 15 to 64 & Thousands & World Development Indicators \\
\hline Employment law index & $\begin{array}{l}\text { Index from } 0 \text { to } 1 \text { from lowest to } \\
\text { highest level of employment } \\
\text { protection }\end{array}$ & Botero et al. (2004) \\
\hline Unemployment benefits & $\begin{array}{l}\text { Index from } 0 \text { to } 1 \text { from least to } \\
\text { most generous system }\end{array}$ & Botero et al. (2004) \\
\hline Public social spending, health & $\%$ of GDP & World Development Indicators \\
\hline Ease of doing business index & $\begin{array}{l}\text { Rank, } 1=\text { most business-friendly } \\
\text { regulations }\end{array}$ & $\begin{array}{l}\text { World Bank Doing Business } \\
\text { Indicators }\end{array}$ \\
\hline Cost of starting a business & $\%$ of $\mathrm{GNI}$ & $\begin{array}{l}\text { World Bank Doing Business } \\
\text { Indicators }\end{array}$ \\
\hline Days required to start a business & Days & $\begin{array}{l}\text { World Bank Doing Business } \\
\text { Indicators }\end{array}$ \\
\hline $\begin{array}{l}\text { Number of procedures to register } \\
\text { a business }\end{array}$ & Number & $\begin{array}{l}\text { World Bank Doing Business } \\
\text { Indicators }\end{array}$ \\
\hline Financial reform index & $\begin{array}{l}\text { Index from } 0 \text { to } 21 \text { from least to } \\
\text { most developed }\end{array}$ & Abiad et al. (2010) \\
\hline
\end{tabular}


Table A1.3. Descriptive statistics - OECD sample

\begin{tabular}{|c|c|c|c|c|c|c|c|c|c|c|}
\hline Variable & Minimum & Maximum & Median & Mean & $\begin{array}{l}\text { Standard } \\
\text { deviation }\end{array}$ & $\begin{array}{c}\text { First } \\
\text { observation }\end{array}$ & $\begin{array}{c}\text { Last } \\
\text { observation }\end{array}$ & $\begin{array}{l}\text { Country } \\
\text { coverage }\end{array}$ & $\begin{array}{c}\text { Total } \\
\text { number of } \\
\text { observations }\end{array}$ & $\begin{array}{c}\text { Share of between } \\
\text { variance in total } \\
\text { variance }^{1}\end{array}$ \\
\hline Total saving rate & 7.58 & 42.06 & 21.82 & 22.07 & 5.72 & 1960 & 2009 & 29 & 1081 & 60.3 \\
\hline Private saving rate & -1.38 & 34.51 & 19.95 & 20.22 & 5.14 & 1960 & 2008 & 29 & 952 & 62.0 \\
\hline Total investment rate & 9.89 & 38.89 & 22.27 & 22.88 & 4.47 & 1960 & 2009 & 30 & 1388 & 43.7 \\
\hline Private investment rate & 7.63 & 32.95 & 18.90 & 19.30 & 3.79 & 1960 & 2009 & 30 & 1215 & 51.0 \\
\hline Current account balance & -25.45 & 18.56 & -0.91 & -0.85 & 4.54 & 1960 & 2009 & 30 & 1083 & 47.3 \\
\hline Government net lending & -31.71 & 18.81 & -2.02 & -1.92 & 4.34 & 1960 & 2008 & 30 & 1084 & 43.1 \\
\hline Real long-term interest rate & -26.04 & 29.25 & 2.92 & 2.76 & 3.54 & 1961 & 2009 & 30 & 1113 & 12.1 \\
\hline Old-age dependency ratio & 5.95 & 32.85 & 18.62 & 18.12 & 5.15 & 1960 & 2008 & 30 & 1470 & 69.9 \\
\hline Youth dependency ratio & 19.87 & 94.57 & 33.88 & 37.01 & 13.49 & 1960 & 2008 & 30 & 1470 & 59.8 \\
\hline Productivity & 6031 & 109,735 & 30,226 & 31,630 & 14,132 & 1960 & 2008 & 30 & 1322 & 45.9 \\
\hline Terms of trade & 0.552 & 1.654 & 1.009 & 1.006 & 0.155 & 1960 & 2009 & 30 & 1324 & 51.8 \\
\hline User cost of capital & -0.368 & 0.485 & 0.161 & 0.162 & 0.062 & 1961 & 2008 & 30 & 1064 & 18.8 \\
\hline Population aged 15 to 64 & 101 & 204,000 & 6,980 & 21,398 & 31,553 & 1960 & 2008 & 30 & 1470 & 95.6 \\
\hline Unemployment benefit replacement rate & 0.00 & 64.94 & 24.70 & 23.98 & 13.78 & 1961 & 2007 & 29 & 1039 & 58.6 \\
\hline Public social spending, old age & 0.16 & 12.82 & 6.32 & 6.32 & 2.70 & 1980 & 2005 & 30 & 699 & 86.3 \\
\hline Public social spending, health & 0.91 & 8.24 & 5.32 & 5.24 & 1.36 & 1980 & 2005 & 30 & 704 & 75.4 \\
\hline Public social spending, total & 1.90 & 32.14 & 19.46 & 18.98 & 6.24 & 1980 & 2005 & 30 & 699 & 89.1 \\
\hline Standard retirement age & 57.50 & 70.00 & 65.00 & 64.14 & 2.42 & 1967 & 2003 & 23 & 603 & 80.0 \\
\hline Employment protection legislation & 0.21 & 4.19 & 2.11 & 2.11 & 1.01 & 1985 & 2009 & 30 & 630 & 90.7 \\
\hline Sub-indicator for regular contracts & 0.17 & 5.00 & 2.25 & 2.15 & 0.87 & 1985 & 2009 & 30 & 630 & 95.4 \\
\hline Sub-indicator for temporary contracts & 0.00 & 5.38 & 1.69 & 2.06 & 1.49 & 1985 & 2009 & 30 & 635 & 81.2 \\
\hline Credit to the private sector & 0.017 & 3.451 & 0.643 & 0.691 & 0.439 & 1960 & 2008 & 30 & 1268 & 43.9 \\
\hline Total value traded on the stock market & 0.000 & 4.279 & 0.194 & 0.439 & 0.609 & 1975 & 2007 & 30 & 621 & 43.6 \\
\hline Stock market capitalization & 0.002 & 3.034 & 0.418 & 0.569 & 0.530 & 1976 & 2007 & 30 & 597 & 64.0 \\
\hline Financial reform index & 0.75 & 21.00 & 16.00 & 14.10 & 5.70 & 1973 & 2005 & 27 & 840 & 23.5 \\
\hline Regulation in seven non-manufacturing sectors & 0.94 & 6.00 & 4.32 & 4.15 & 1.41 & 1975 & 2007 & 30 & 898 & 29.4 \\
\hline
\end{tabular}

1. Percentage of the sample variance of the variable that can be attributed to differences in the mean across countries. Alternatively, this can be interpreted as the percentage of the variance of the variable captured by country fixed effects in the regressions. 
ECO/WKP(2010)71

Table A1.4. Panel unit root tests for dependent and macroeconomic control variables - OECD sample

\begin{tabular}{|c|c|c|c|c|c|c|}
\hline & \multicolumn{3}{|c|}{ Individual intercepts } & \multicolumn{3}{|c|}{ Individual intercepts and linear trends } \\
\hline & LLC $^{1}$ & $\mathrm{IPS}^{2}$ & ADF-F ${ }^{3}$ & LLC & IPS & ADF-F \\
\hline Total saving rate & $-3.837^{* * *}$ & $-3.238^{* * *}$ & $88.681^{* \star *}$ & $-2.156^{\star *}$ & $-2.108^{* *}$ & $82.429^{* *}$ \\
\hline Private saving rate & $-2.374^{* * *}$ & $-4.153^{* * *}$ & $118.066^{* * *}$ & $-2.665^{\star \star *}$ & $-5.274^{\star * *}$ & $125.777^{* * *}$ \\
\hline Total investment rate & $-2.820^{\star * *}$ & $-4.208^{\star * \star}$ & $113.870^{\star \star \star}$ & $-3.281^{* * *}$ & $-5.801^{* * *}$ & $135.215^{\star * *}$ \\
\hline Private investment rate & $-3.993^{* * *}$ & $-4.777^{* * *}$ & $127.578^{* * *}$ & $-3.447^{* * *}$ & $-5.166^{* * *}$ & $125.643^{* * *}$ \\
\hline $\begin{array}{l}\text { Current account } \\
\text { balance }\end{array}$ & $-2.652^{* \star *}$ & $-4.403^{\star * \star}$ & $118.999^{* * *}$ & $-3.836^{\star * \star}$ & $-4.433^{* \star *}$ & $123.720^{* * *}$ \\
\hline $\begin{array}{l}\text { Government net } \\
\text { lending }\end{array}$ & $-2.398^{* * *}$ & $-4.699^{\star * \star}$ & $141.262^{* * *}$ & $-1.498^{*}$ & $-3.602^{* \star *}$ & $116.346^{* \star *}$ \\
\hline $\begin{array}{l}\text { Real long-term interest } \\
\text { rate }\end{array}$ & $-1.972^{\star *}$ & $-4.112^{\star * \star}$ & $110.762^{* \star \star}$ & $-4.507^{\star * \star}$ & $-4.277^{\star \star \star}$ & $117.974^{* \star *}$ \\
\hline $\begin{array}{l}\text { Old-age dependency } \\
\text { ratio }\end{array}$ & 7.592 & 8.131 & 18.083 & 3.953 & $-4.866^{\star * *}$ & $199.532^{* * *}$ \\
\hline $\begin{array}{l}\text { Youth dependency } \\
\text { ratio }\end{array}$ & $-5.847^{\star * \star}$ & $-1.647^{* \star}$ & $116.869^{* * *}$ & 12.987 & $-2.686^{\star * *}$ & $138.830^{* * *}$ \\
\hline Productivity growth & $-17.170^{* * *}$ & $-18.322^{* * *}$ & $439.452^{* * *}$ & $-15.603^{* * *}$ & $-15.918^{* * *}$ & $368.533^{* * *}$ \\
\hline $\begin{array}{l}\text { Change in terms of } \\
\text { trade }\end{array}$ & $-27.783^{\star \star \star}$ & $-26.120^{* * *}$ & $661.908^{* * *}$ & $-24.453^{* * *}$ & $-22.848^{* \star *}$ & $551.813^{\star \star *}$ \\
\hline User cost of capital & $-3.724^{* * *}$ & $-3.720^{* * *}$ & $111.341^{* \star *}$ & $-3.342^{\star * *}$ & $-2.886^{* * *}$ & $112.343^{* * *}$ \\
\hline $\begin{array}{l}\text { Change in population } \\
\text { aged } 15-64\end{array}$ & 1.850 & $-3.562^{\star \star \star}$ & $118.988^{\star * *}$ & -0.479 & $-4.779^{* * *}$ & $125.780^{* * *}$ \\
\hline
\end{tabular}

Note: * ${ }^{* *}$ and ${ }^{* * *}$ denote rejection of the null-hypothesis that the variable is non-stationary at respectively the $10 \%, 5 \%$ and $1 \%$ significance level.

1. $t^{*}$ test statistic by Levin, A., C.F. Lin and C. Chu (2002), "Unit Root Tests in Panel Data: Asymptotic and Finite-Sample Properties", Journal of Econometrics, Vol. 108, pp. 1-24.

2. W-stat test statistic by Im, K.S., M.H. Pesaran and Y. Shin (2003). "Testing for Unit Roots in Heterogeneous Panels", Journal of Econometrics, Vol. 115, pp. 53-74.

3. ADF-Fisher Chi-square test statistic by Maddala, G.S. and S. Wu (1999), "A Comparative Study of Unit Root Tests with Panel Data and a New Simple Test", Oxford Bulletin of Economics and Statistics, Vol. 61, pp. 631-652; and Choi, I. (2001), "Unit Root Tests for Panel Data", Journal of International Money and Finance, Vol. 20, pp. 249-272. 
Table A1.5. Baseline estimation results for OECD sample 1965-2008 - country fixed effects and time trends

\begin{tabular}{|c|c|c|c|c|c|}
\hline & SAVT & SAVP & INVT & INVP & $\mathrm{CA}$ \\
\hline \multicolumn{6}{|l|}{ Long-run relationship } \\
\hline User cost of capital & & & $\begin{array}{l}-0.242^{* * *} \\
(0.043)\end{array}$ & $\begin{array}{l}-0.206^{\star * *} \\
(0.038)\end{array}$ & $\begin{array}{l}-0.089 \\
(0.081)\end{array}$ \\
\hline Productivity growth & $\begin{array}{l}0.810^{\star \star \star} \\
(0.173)\end{array}$ & $\begin{array}{l}0.455^{\star \star *} \\
(0.143)\end{array}$ & $\begin{array}{l}1.636^{\star \star \star} \\
(0.241)\end{array}$ & $\begin{array}{l}1.414^{\star * \star} \\
(0.202)\end{array}$ & $\begin{array}{l}-0.641^{* *} \\
(0.281)\end{array}$ \\
\hline Change in population aged $15-64$ & & & $\begin{array}{l}3.074^{\star * *} \\
(0.528)\end{array}$ & $\begin{array}{l}2.276^{\star * *} \\
(0.449)\end{array}$ & $\begin{array}{l}-5.533^{\star * *} \\
(0.825)\end{array}$ \\
\hline Change in terms of trade & $\begin{array}{l}0.285^{\star \star *} \\
(0.050)\end{array}$ & $\begin{array}{l}0.213^{* * *} \\
(0.039)\end{array}$ & & & $\begin{array}{l}0.177^{* *} \\
(0.073)\end{array}$ \\
\hline Real long-term interest rate & $\begin{array}{l}-0.274^{* * *} \\
(0.095)\end{array}$ & $\begin{array}{l}-0.209^{* *} \\
(0.083)\end{array}$ & & & $\begin{array}{l}-0.022 \\
(0.168)\end{array}$ \\
\hline Old-age dependency ratio & $\begin{array}{l}-0.552^{\star \star \star} \\
(0.108)\end{array}$ & $\begin{array}{l}-0.061 \\
(0.130)\end{array}$ & & & $\begin{array}{l}-0.342 \\
(0.241)\end{array}$ \\
\hline Youth dependency ratio & $\begin{array}{l}-0.137^{*} \\
(0.076)\end{array}$ & $\begin{array}{l}-0.212^{* \star *} \\
(0.062)\end{array}$ & & & $\begin{array}{l}-0.105 \\
(0.108)\end{array}$ \\
\hline Government net lending & $\begin{array}{l}0.411^{\star \star *} \\
(0.074)\end{array}$ & $\begin{array}{l}-0.372^{\star \star \star} \\
(0.066)\end{array}$ & & & $\begin{array}{c}0.071 \\
(0.077) \\
\end{array}$ \\
\hline \multicolumn{6}{|l|}{ Short-run dynamics } \\
\hline Error correction parameter & $\begin{array}{l}-0.374^{* * *} \\
(0.056)\end{array}$ & $\begin{array}{l}-0.438^{* * *} \\
(0.050)\end{array}$ & 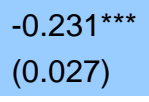 & $\begin{array}{l}-0.240^{\star * *} \\
(0.024)\end{array}$ & $\begin{array}{l}-0.412^{* * *} \\
(0.046)\end{array}$ \\
\hline$\Sigma \Delta$ Dependent variable & & $\begin{array}{c}0.094^{*} \\
(0.048)\end{array}$ & $\begin{array}{c}0.076 \\
(0.073)\end{array}$ & $\begin{array}{l}0.171^{\star * *} \\
(0.056)\end{array}$ & $\begin{array}{l}0.127^{\star *} \\
(0.049)\end{array}$ \\
\hline$\Sigma \Delta$ User cost of capital & & & $\begin{array}{c}0.011 \\
(0.017)\end{array}$ & $\begin{array}{l}-0.037^{* * *} \\
(0.008)\end{array}$ & \\
\hline$\Sigma \Delta$ Productivity growth & $\begin{array}{l}0.288^{\star * \star} \\
(0.051)\end{array}$ & $\begin{array}{l}0.179 * * * \\
(0.048)\end{array}$ & $\begin{array}{l}0.186^{\star \star \star} \\
(0.033)\end{array}$ & $\begin{array}{l}0.250^{\star * *} \\
(0.026)\end{array}$ & $\begin{array}{l}-0.202^{\star \star} \\
(0.097)\end{array}$ \\
\hline$\Sigma \Delta$ Change in population aged $15-64$ & & & $\begin{array}{c}0.206 \\
(0.199)\end{array}$ & $\begin{array}{c}0.211 \\
(0.158)\end{array}$ & $\begin{array}{c}1.347 \\
(0.853)\end{array}$ \\
\hline$\Sigma \Delta$ Change in terms of trade & $\begin{array}{l}0.093^{\star * *} \\
(0.013)\end{array}$ & $\begin{array}{l}0.051^{\text {***}} \\
(0.000)\end{array}$ & & & $\begin{array}{l}0.093^{* * *} \\
(0.027)\end{array}$ \\
\hline$\Sigma \Delta$ Real long-term interest rate & $\begin{array}{l}-0.157^{* \star *} \\
(0.041)\end{array}$ & $\begin{array}{l}-0.108^{* *} \\
(0.044)\end{array}$ & & & $\begin{array}{l}-0.156^{* * *} \\
(0.044)\end{array}$ \\
\hline$\Sigma \Delta$ Old-age dependency ratio & $\begin{array}{l}1.099^{* * *} \\
(0.312)\end{array}$ & $\begin{array}{l}1.062^{\text {***}} \\
(0.245)\end{array}$ & & & \\
\hline$\Sigma \Delta$ Youth dependency ratio & $\begin{array}{l}-0.337^{\star * *} \\
(0.118)\end{array}$ & $\begin{array}{l}-0.248^{* *} \\
(0.124)\end{array}$ & & & $\begin{array}{l}-1.143^{* * *} \\
(0.257)\end{array}$ \\
\hline$\Sigma \Delta$ Government net lending & $\begin{array}{l}0.132^{\star \star \star} \\
(0.046)\end{array}$ & $\begin{array}{l}-0.468^{\star \star \star} \\
(0.048)\end{array}$ & & & $\begin{array}{l}0.153^{\star * *} \\
(0.055)\end{array}$ \\
\hline
\end{tabular}

Note: Robust standard errors in parentheses. * , ** and *** denote significance at the 10\%, 5\% and $1 \%$ significance level. SAVT, SAVP, INVT, INVP, and CA denote the GDP shares of respectively total saving, private saving, total investment, private investment, and the current account balance. All models include country fixed effects and country-specific time trends. 
Table A1.6. Baseline estimation results for OECD sample 1965-2008 - exclusion of influential data points

\begin{tabular}{|c|c|c|c|c|c|}
\hline & SAVT & SAVP & INVT & INVP & $\mathrm{CA}$ \\
\hline \multicolumn{6}{|l|}{ Long-run relationship } \\
\hline User cost of capital & & & $\begin{array}{c}-0.371^{* * *} \\
(0.104)\end{array}$ & $\begin{array}{c}-0.460^{\star \star \star} \\
(0.106)\end{array}$ & $\begin{array}{l}-0.184 \\
(0.154)\end{array}$ \\
\hline Productivity growth & $\begin{array}{l}0.801^{* *} \\
(0.326)\end{array}$ & $\begin{array}{c}0.391 \\
(0.248)\end{array}$ & $\begin{array}{c}2.655^{\star \star \star} \\
(0.484)\end{array}$ & $\begin{array}{c}2.407^{\star * *} \\
(0.376)\end{array}$ & $\begin{array}{c}-1.809^{* * *} \\
(0.444)\end{array}$ \\
\hline Change in population aged $15-64$ & & & $\begin{array}{c}2.853^{\star * *} \\
(0.703)\end{array}$ & $\begin{array}{c}1.938^{* * *} \\
(0.581)\end{array}$ & $\begin{array}{c}-6.963^{* * *} \\
(1.690)\end{array}$ \\
\hline Change in terms of trade & $\begin{array}{c}0.483^{* * *} \\
(0.130)\end{array}$ & $\begin{array}{c}0.194^{* * *} \\
(0.074)\end{array}$ & & & $\begin{array}{l}0.509^{* *} \\
(0.211)\end{array}$ \\
\hline Real long-term interest rate & $\begin{array}{c}-0.691^{\text {** }} \\
(0.223)\end{array}$ & $\begin{array}{c}-0.534^{\star \star *} \\
(0.182)\end{array}$ & & & $\begin{array}{c}0.175 \\
(0.312)\end{array}$ \\
\hline Old-age dependency ratio & $\begin{array}{c}-0.488^{* * *} \\
(0.155)\end{array}$ & $\begin{array}{c}-0.322^{* *} \\
(0.160)\end{array}$ & & & $\begin{array}{c}-1.092^{* * *} \\
(0.243)\end{array}$ \\
\hline Youth dependency ratio & $\begin{array}{l}0.534^{\star *} \\
(0.213)\end{array}$ & $\begin{array}{c}0.380^{\star * *} \\
(0.123)\end{array}$ & & & $\begin{array}{c}0.509^{\star * *} \\
(0.188)\end{array}$ \\
\hline Government net lending & $\begin{array}{c}0.405^{\star \star \star} \\
(0.117)\end{array}$ & $\begin{array}{c}-0.542^{\star * *} \\
(0.101)\end{array}$ & & & $\begin{array}{c}-0.378^{\star *} \\
(0.189)\end{array}$ \\
\hline \multicolumn{6}{|l|}{ Short-run dynamics } \\
\hline Error correction parameter & $\begin{array}{c}-0.171^{* \star *} \\
(0.031)\end{array}$ & $\begin{array}{c}-0.217^{\star \star *} \\
(0.028)\end{array}$ & $\begin{array}{c}-0.135^{\star \star *} \\
(0.023)\end{array}$ & $\begin{array}{c}-0.148^{\star * *} \\
(0.020)\end{array}$ & $\begin{array}{c}-0.141^{* * *} \\
(0.025)\end{array}$ \\
\hline$\Sigma \Delta$ Dependent variable & $\begin{array}{c}-0.116^{\star * *} \\
(0.042)\end{array}$ & & $\begin{array}{l}0.102^{* *} \\
(0.051)\end{array}$ & $\begin{array}{c}0.005 \\
(0.060)\end{array}$ & $\begin{array}{c}-0.087^{* * *} \\
(0.033)\end{array}$ \\
\hline$\Sigma \Delta$ User cost of capital & & & $\begin{array}{l}-0.017 \\
(0.019)\end{array}$ & $\begin{array}{c}-0.053^{* * *} \\
(0.012)\end{array}$ & \\
\hline$\Sigma \Delta$ Productivity growth & $\begin{array}{c}0.438^{\star * \star} \\
(0.046)\end{array}$ & $\begin{array}{c}0.227^{* \star *} \\
(0.064)\end{array}$ & $\begin{array}{c}0.326^{\star \star \star} \\
(0.030)\end{array}$ & $\begin{array}{c}0.301^{* * *} \\
(0.019)\end{array}$ & $\begin{array}{c}-0.190^{\star * *} \\
(0.042)\end{array}$ \\
\hline$\Sigma \Delta$ Change in population aged $15-64$ & & & $\begin{array}{c}0.398^{* * *} \\
(0.106)\end{array}$ & & $\begin{array}{c}0.899^{\star * *} \\
(0.274)\end{array}$ \\
\hline$\Sigma \Delta$ Change in terms of trade & $\begin{array}{c}0.099^{* * *} \\
(0.015)\end{array}$ & $\begin{array}{c}0.047^{* * \star} \\
(0.016)\end{array}$ & & & $\begin{array}{c}0.123^{\star \star \star} \\
(0.024)\end{array}$ \\
\hline$\Sigma \Delta$ Real interest rate & $\begin{array}{c}-0.066^{\star *} \\
(0.028)\end{array}$ & $\begin{array}{c}-0.053^{* *} \\
(0.026)\end{array}$ & & & $\begin{array}{c}-0.092^{* *} \\
(0.040)\end{array}$ \\
\hline$\Sigma \Delta$ Old-age dependency ratio & $\begin{array}{l}0.600^{* *} \\
(0.234)\end{array}$ & $\begin{array}{c}0.155 \\
(0.355)\end{array}$ & & & \\
\hline$\Sigma \Delta$ Youth dependency ratio & $\begin{array}{c}-0.471^{* * *} \\
(0.162)\end{array}$ & $\begin{array}{c}-0.343^{* *} \\
(0.170)\end{array}$ & & & $\begin{array}{c}-0.687^{* * *} \\
(0.171)\end{array}$ \\
\hline$\Sigma \Delta$ Government net lending & $\begin{array}{c}0.180^{\star * *} \\
(0.033)\end{array}$ & $\begin{array}{c}-0.409^{* * *} \\
(0.042)\end{array}$ & & & $\begin{array}{l}0.081^{\star *} \\
(0.038)\end{array}$ \\
\hline
\end{tabular}

Note: Robust standard errors in parentheses. ${ }^{*},{ }^{* *}$ and ${ }^{* * *}$ denote significance at the $10 \%, 5 \%$ and $1 \%$ significance level. SAVT, SAVP, INVT, INVP, and CA denote the GDP shares of respectively total saving, private saving, total investment, private investment, and the current account balance. All models include country and period fixed effects. A data point is classified as influential if its inclusion alters the point estimate of one or more coefficients (excluding dummies) in the baseline specification by more than $1 / 2$ standard error. 
Table A1.7. Alternative baseline estimation results for OECD sample 1965-2008

\begin{tabular}{|c|c|c|c|}
\hline & SAVT & SAVP & $\mathrm{CA}$ \\
\hline \multicolumn{4}{|l|}{ Long-run relationship } \\
\hline User cost of capital & & & $\begin{array}{c}0.094 \\
(0.154)\end{array}$ \\
\hline Productivity growth & $\begin{array}{l}-1.100^{* * *} \\
(0.386)\end{array}$ & $\begin{array}{l}-0.560^{* *} \\
(0.250)\end{array}$ & $\begin{array}{l}1.300^{* * *} \\
(0.132)\end{array}$ \\
\hline Change in population aged $15-64$ & & & $\begin{array}{l}4.134^{\star \star *} \\
(1.545)\end{array}$ \\
\hline Change in terms of trade & $\begin{array}{l}-0.243^{\star *} \\
(0.128)\end{array}$ & $\begin{array}{l}-0.055 \\
(0.097)\end{array}$ & $\begin{array}{l}-0.141 \\
(0.244)\end{array}$ \\
\hline Real long-term interest rate & $\begin{array}{l}0.643^{* * *} \\
(0.227)\end{array}$ & $\begin{array}{l}0.503^{\star * *} \\
(0.201)\end{array}$ & $\begin{array}{c}0.007 \\
(0.314)\end{array}$ \\
\hline Old-age dependency ratio & $\begin{array}{l}0.519^{\star * *} \\
(0.145)\end{array}$ & $\begin{array}{l}0.331^{\star *} \\
(0.150)\end{array}$ & $\begin{array}{l}0.623^{\star * *} \\
(0.206)\end{array}$ \\
\hline Youth dependency ratio & $\begin{array}{l}-0.291^{* *} \\
(0.146)\end{array}$ & $\begin{array}{l}-0.417^{* * *} \\
(0.136)\end{array}$ & $\begin{array}{l}-0.250^{\star *} \\
(0.132)\end{array}$ \\
\hline Government net lending & $\begin{array}{l}-0.288^{\star *} \\
(0.120)\end{array}$ & $\begin{array}{l}0.632^{\star * *} \\
(0.105)\end{array}$ & $\begin{array}{c}0.015 \\
(0.156)\end{array}$ \\
\hline Oil exporter dummy & $\begin{array}{c}0.879 \\
(1.111)\end{array}$ & $\begin{array}{l}-0.652 \\
(0.861)\end{array}$ & $\begin{array}{c}0.301 \\
(1.441)\end{array}$ \\
\hline Change in terms of trade ${ }^{\star}$ Oil exporter dummy & $\begin{array}{l}-0.601^{* \star *} \\
(0.187)\end{array}$ & $\begin{array}{l}-0.407^{\star * *} \\
(0.138)\end{array}$ & $\begin{array}{l}-0.586^{\star * *} \\
(0.188)\end{array}$ \\
\hline \multicolumn{4}{|l|}{ Short-run dynamics } \\
\hline Error correction parameter & $\begin{array}{l}-0.183^{\star \star *} \\
(0.037)\end{array}$ & $\begin{array}{l}-0.229^{* * *} \\
(0.038)\end{array}$ & $\begin{array}{l}-0.224^{* * *} \\
(0.037)\end{array}$ \\
\hline$\Sigma \Delta$ Dependent variable & $\begin{array}{l}-0.105^{\star \star} \\
(0.041)\end{array}$ & & \\
\hline$\Sigma \Delta$ Productivity growth & $\begin{array}{l}0.226^{\star * *} \\
(0.055)\end{array}$ & $\begin{array}{c}0.058 \\
(0.082)\end{array}$ & $\begin{array}{l}-0.216^{* *} \\
(0.099)\end{array}$ \\
\hline$\Sigma \Delta$ Change in population aged $15-64$ & & & $\begin{array}{l}-1.005^{\text {** }} \\
(0.368)\end{array}$ \\
\hline$\Sigma \Delta$ Change in terms of trade & $\begin{array}{l}0.085^{\text {***}} \\
(0.016)\end{array}$ & $\begin{array}{c}0.046^{\star * *} \\
(0.016)\end{array}$ & $\begin{array}{l}0.180^{\text {***}} \\
(0.066)\end{array}$ \\
\hline$\Sigma \Delta$ Real interest rate & $\begin{array}{l}-0.075^{\star \star \star} \\
(0.027)\end{array}$ & $\begin{array}{l}-0.052^{*} \\
(0.027)\end{array}$ & $\begin{array}{l}-0.146^{\star *} \\
(0.058)\end{array}$ \\
\hline$\Sigma \Delta$ Old-age dependency ratio & $\begin{array}{l}0.581^{\star *} \\
(0.234)\end{array}$ & $\begin{array}{c}0.324 \\
(0.355)\end{array}$ & \\
\hline$\Sigma \Delta$ Youth dependency ratio & $\begin{array}{l}-0.557^{\text {***}} \\
(0.138)\end{array}$ & $\begin{array}{l}-0.384^{\star *} \\
(0.176)\end{array}$ & $\begin{array}{l}-0.805^{\text {** }} \\
(0.282)\end{array}$ \\
\hline$\Sigma \Delta$ Government net lending & $\begin{array}{l}0.167^{\star \star *} \\
(0.033)\end{array}$ & $\begin{array}{l}-0.427^{* * *} \\
(0.043)\end{array}$ & $\begin{array}{c}0.098 \\
(0.061)\end{array}$ \\
\hline$\Sigma \Delta$ Oil exporter dummy & $\begin{array}{c}0.100 \\
(0.189)\end{array}$ & $\begin{array}{l}-0.369 \\
(0.315)\end{array}$ & $\begin{array}{l}-0.140 \\
(1.519)\end{array}$ \\
\hline$\Sigma \Delta$ Change in terms of trade * Oil exporter dummy & $\begin{array}{l}-0.075^{\star \star *} \\
(0.027)\end{array}$ & $\begin{array}{l}-0.085^{\star *} \\
(0.034)\end{array}$ & $\begin{array}{l}-0.116^{*} \\
(0.064)\end{array}$ \\
\hline
\end{tabular}

Note: Robust standard errors in parentheses. ${ }^{*},{ }^{* *}$ and ${ }^{* * *}$ denote significance at the $10 \%, 5 \%$ and $1 \%$ significance level. SAVT, SAVP and CA denote the GDP shares of respectively total saving, private saving, total investment, private investment, and the current account balance. All models include country and period fixed effects. The following countries are classified as oil exporting: Australia (1986-2008), Canada (1972 to 1974 and 1982 to 2008), Denmark (1997 to 2008), Mexico (1975 to 2008), Norway (1975 to 2008), United Kingdom (1981 to 2005). 
Table A1.8. The impact of structural policies on saving, investment and current accounts in OECD countries-country fixed effects and time trends

\begin{tabular}{|c|c|c|c|c|c|c|c|c|c|c|}
\hline & \multicolumn{2}{|c|}{ SAVT } & \multicolumn{2}{|c|}{ SAVP } & \multicolumn{2}{|c|}{ INVT } & \multicolumn{2}{|c|}{$\begin{array}{l}\text { INVP } \\
\end{array}$} & \multicolumn{2}{|c|}{ CA } \\
\hline & LR & SR & LR & SR & LR & SR & LR & SR & LR & SR \\
\hline \multicolumn{11}{|l|}{ Social security programs } \\
\hline $\begin{array}{l}\text { Unemployment benefit } \\
\text { replacement rate }\end{array}$ & $\begin{array}{l}-0.075^{\star * *} \\
(0.027)\end{array}$ & & $\begin{array}{l}-0.073^{* * *} \\
(0.023)\end{array}$ & & & & & & $\begin{array}{l}-0.106^{* * *} \\
(0.040)\end{array}$ & \\
\hline Public social spending, total & $\begin{array}{l}-0.324^{\star *} \\
(0.140)\end{array}$ & & $\begin{array}{l}-0.315^{\star \star} \\
(0.129)\end{array}$ & & & & & & $\begin{array}{l}-0.349 \\
(0.224)\end{array}$ & \\
\hline Public social spending, old age & $\begin{array}{l}-0.812^{* *} \\
(0.364)\end{array}$ & & $\begin{array}{l}-0.718^{*} \\
(0.375)\end{array}$ & & & & & & $\begin{array}{l}-1.273^{\star *} \\
(0.620)\end{array}$ & \\
\hline Public social spending, health & $\begin{array}{l}-0.907^{* *} \\
(0.448)\end{array}$ & & $\begin{array}{l}-1.008^{\star * *} \\
(0.321)\end{array}$ & & & & & & $\begin{array}{l}-1.352^{* * *} \\
(0.522)\end{array}$ & \\
\hline Standard retirement age & $\begin{array}{l}-0.025 \\
(0.197) \\
\end{array}$ & & $\begin{array}{l}-0.182 \\
(0.196) \\
\end{array}$ & & & & & & $\begin{array}{l}-0.056 \\
(0.208) \\
\end{array}$ & \\
\hline \multicolumn{11}{|l|}{ Labour market policy } \\
\hline Employ. protection legislation (EPL) & $\begin{array}{l}1.045^{\star \star} \\
(0.479)\end{array}$ & & $\begin{array}{l}0.773^{*} \\
(0.429)\end{array}$ & & $\begin{array}{l}1.599^{\star \star \star} \\
(0.521)\end{array}$ & & $\begin{array}{r}1.136^{*} \\
(0.579)\end{array}$ & & $\begin{array}{c}1.236 \\
(0.828)\end{array}$ & \\
\hline EPL on regular contracts & $\begin{array}{l}2.855^{* *} \\
(1.444)\end{array}$ & & $\begin{array}{l}2.080^{* *} \\
(0.938)\end{array}$ & & $\begin{array}{c}0.942 \\
(0.674)\end{array}$ & & $\begin{array}{l}0.737 \\
(0.453)\end{array}$ & & $\begin{array}{c}1.128 \\
(1.770)\end{array}$ & \\
\hline EPL on temporary contracts & $\begin{array}{c}0.289 \\
(0.264) \\
\end{array}$ & & $\begin{array}{c}0.232 \\
(0.265) \\
\end{array}$ & & $\begin{array}{l}0.968^{\star *} \\
(0.466) \\
\end{array}$ & & $\begin{array}{r}0.666^{*} \\
(0.375) \\
\end{array}$ & & $\begin{array}{c}0.602 \\
(0.381) \\
\end{array}$ & \\
\hline \multicolumn{11}{|l|}{ Financial market regulation } \\
\hline $\begin{array}{l}\text { Credit to the private sector } \\
\text { (\% of GDP) }\end{array}$ & $\begin{array}{l}-1.208^{*} \\
(0.636)\end{array}$ & $\begin{array}{r}0.537^{*} \\
(0.302)\end{array}$ & $\begin{array}{l}-1.086^{*} \\
(0.612)\end{array}$ & & $\begin{array}{l}2.221^{* * *} \\
(0.820)\end{array}$ & $\begin{array}{l}1.182^{\star \star *} \\
(0.438)\end{array}$ & $\begin{array}{l}1.616^{\star *} \\
(0.718)\end{array}$ & $\begin{array}{l}0.987^{* *} \\
(0.393)\end{array}$ & $\begin{array}{l}-2.302^{\star * *} \\
(0.774)\end{array}$ & $\begin{array}{l}1.114^{\star *} \\
(0.555)\end{array}$ \\
\hline Stock market capitalization(\% of GDP) & $\begin{array}{c}0.837 \\
(1.240)\end{array}$ & $\begin{array}{l}-0.994^{\star} \\
(0.537)\end{array}$ & $\begin{array}{l}0.813 \\
(0.599)\end{array}$ & & $\begin{array}{l}0.402 \\
(0.572)\end{array}$ & $\begin{array}{l}-0.683^{*} \\
(0.371)\end{array}$ & $\begin{array}{l}-0.128 \\
(0.824)\end{array}$ & & $\begin{array}{l}-0.518 \\
(1.295)\end{array}$ & \\
\hline Stock market trade (\% of GDP) & $\begin{array}{l}-0.912^{*} \\
(0.534)\end{array}$ & & $\begin{array}{l}-0.731 \\
(0.455)\end{array}$ & $\begin{array}{l}-0.485^{\star \star} \\
(0.237)\end{array}$ & $\begin{array}{l}0.207 \\
(0.593)\end{array}$ & & $\begin{array}{l}-0.661 \\
(0.492)\end{array}$ & $\begin{array}{r}0.284^{*} \\
(0.146)\end{array}$ & $\begin{array}{l}-1.387 \\
(0.888)\end{array}$ & $\begin{array}{l}0.872^{\star \star *} \\
(0.230)\end{array}$ \\
\hline Financial reform index & $\begin{array}{c}0.095 \\
(0.092) \\
\end{array}$ & & $\begin{array}{l}-0.006 \\
(0.093) \\
\end{array}$ & & $\begin{array}{l}-0.263^{*} \\
(0.155) \\
\end{array}$ & $\begin{array}{l}0.201^{* * *} \\
(0.038) \\
\end{array}$ & $\begin{array}{l}-0.266^{\star *} \\
(0.133) \\
\end{array}$ & $\begin{array}{l}0.153^{\star \star \star} \\
(0.053) \\
\end{array}$ & $\begin{array}{c}0.108 \\
(0.132) \\
\end{array}$ & \\
\hline \multicolumn{11}{|l|}{ Product market regulation } \\
\hline $\begin{array}{l}\text { Regulation in seven non-manufacturing } \\
\text { sectors }\end{array}$ & & & & & $\begin{array}{c}0.981 \\
(0.620)\end{array}$ & $\begin{array}{l}0.824^{\star \star \star} \\
(0.318)\end{array}$ & $\begin{array}{l}0.897^{*} \\
(0.480)\end{array}$ & $\begin{array}{l}-0.745^{\star \star} \\
(0.350)\end{array}$ & $\begin{array}{c}0.206 \\
(0.532)\end{array}$ & \\
\hline
\end{tabular}

Note: Robust standard errors in parentheses. ${ }^{*},{ }^{* *}$ and ${ }^{* * *}$ denote significance at the $10 \%, 5 \%$ and $1 \%$ significance level. SAVT, SAVP, INVT, INVP, and CA denote the GDP shares of respectively total

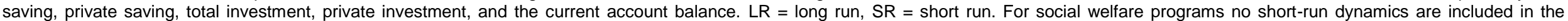
specifications due to linear interpolation of the data. All specifications include country fixed effects and country-specific time trends. 
ECO/WKP(2010)71

Table A1.9. The impact of structural policies on saving, investment and current accounts in OECD countries - exclusion of influential data points

\begin{tabular}{|c|c|c|c|c|c|c|c|c|c|c|}
\hline & \multicolumn{2}{|c|}{ SAVT } & \multicolumn{2}{|c|}{ SAVP } & \multicolumn{2}{|c|}{ INVT } & \multicolumn{2}{|c|}{$\begin{array}{l}\text { INVP } \\
\end{array}$} & \multicolumn{2}{|c|}{ CA } \\
\hline & LR & SR & LR & SR & LR & SR & LR & SR & LR & SR \\
\hline \multicolumn{11}{|l|}{ Social security programs } \\
\hline $\begin{array}{l}\text { Unemployment benefit } \\
\text { replacement rate }\end{array}$ & $\begin{array}{l}0.010 \\
(0.064)\end{array}$ & & $\begin{array}{l}-0.013 \\
(0.051)\end{array}$ & & & & & & $\begin{array}{l}-0.148^{* *} \\
(0.071)\end{array}$ & \\
\hline Public social spending, total & $\begin{array}{l}-0.271 \\
(0.175)\end{array}$ & & $\begin{array}{l}-0.248 \\
(0.182)\end{array}$ & & & & & & $\begin{array}{l}-0.508^{*} \\
(0.276)\end{array}$ & \\
\hline Public social spending, old age & $\begin{array}{l}-0.286 \\
(0.427)\end{array}$ & & $\begin{array}{l}0.090 \\
(0.476)\end{array}$ & & & & & & $\begin{array}{l}-0.239 \\
(0.676)\end{array}$ & \\
\hline Public social spending, health & $\begin{array}{l}-1.679^{* * *} \\
(0.561)\end{array}$ & & $\begin{array}{l}-1.558^{* * *} \\
(0.498)\end{array}$ & & & & & & $\begin{array}{l}-3.035^{* * *} \\
(0.643)\end{array}$ & \\
\hline Standard retirement age & $\begin{array}{l}-0.611^{* *} \\
(0.304) \\
\end{array}$ & & $\begin{array}{l}-0.749^{* * *} \\
(0.289) \\
\end{array}$ & & & & & & $\begin{array}{l}-0.992^{* *} \\
(0.435) \\
\end{array}$ & \\
\hline \multicolumn{11}{|l|}{ Labour market policy } \\
\hline Employ. protection legislation (EPL) & $\begin{array}{l}-0.634 \\
(0.608)\end{array}$ & & $\begin{array}{l}-0.136 \\
(0.439)\end{array}$ & & $\begin{array}{l}1.119^{\star \star} \\
(0.534)\end{array}$ & & $\begin{array}{c}0.557 \\
(0.416)\end{array}$ & & $\begin{array}{l}-2.523^{\star \star} \\
(1.137)\end{array}$ & \\
\hline EPL on regular contracts & $\begin{array}{l}-0.602 \\
(0.958)\end{array}$ & & $\begin{array}{l}0.175 \\
(0.722)\end{array}$ & & $\begin{array}{c}0.131 \\
(0.681)\end{array}$ & & $\begin{array}{l}0.021 \\
(0.454)\end{array}$ & & $\begin{array}{l}-2.194 \\
(1.377)\end{array}$ & \\
\hline EPL on temporary contracts & $\begin{array}{l}-0.212 \\
(0.325) \\
\end{array}$ & & $\begin{array}{l}-0.075 \\
(0.302) \\
\end{array}$ & & $\begin{array}{l}0.976^{\star \star \star} \\
(0.362) \\
\end{array}$ & & $\begin{array}{c}0.324 \\
(0.257) \\
\end{array}$ & & $\begin{array}{l}-1.246^{*} \\
(0.643) \\
\end{array}$ & \\
\hline \multicolumn{11}{|l|}{ Financial market regulation } \\
\hline $\begin{array}{l}\text { Credit to the private sector } \\
\text { (\% of GDP) }\end{array}$ & $\begin{array}{l}-2.527^{*} \\
(1.311)\end{array}$ & $\begin{array}{l}-0.687 \\
(0.610)\end{array}$ & $\begin{array}{l}-2.517^{* *} \\
(1.212)\end{array}$ & $\begin{array}{l}-0.981^{\star *} \\
(0.389)\end{array}$ & $\begin{array}{c}1.703 \\
(1.291)\end{array}$ & $\begin{array}{l}1.054^{\star *} \\
(0.413)\end{array}$ & $\begin{array}{c}1.094 \\
(0.870)\end{array}$ & $\begin{array}{l}0.811^{* *} \\
(0.385)\end{array}$ & $\begin{array}{l}-4.050^{\star *} \\
(1.689)\end{array}$ & \\
\hline Stock market capitalization(\% of GDP) & $\begin{array}{l}-0.881 \\
(2.153)\end{array}$ & $\begin{array}{l}-0.034 \\
(0.590)\end{array}$ & $\begin{array}{c}0.249 \\
(1.061)\end{array}$ & $\begin{array}{l}-0.507 \\
(0.737)\end{array}$ & $\begin{array}{c}2.473 \\
(1.730)\end{array}$ & & $\begin{array}{l}2.821^{* *} \\
(1.431)\end{array}$ & $\begin{array}{l}0.484^{* * *} \\
(0.153)\end{array}$ & $\begin{array}{l}-3.438 \\
(2.308)\end{array}$ & $\begin{array}{l}-1.195^{* *} \\
(0.592)\end{array}$ \\
\hline Stock market trade (\% of GDP) & $\begin{array}{l}0.391 \\
(0.849)\end{array}$ & $\begin{array}{l}-0.516^{\star *} \\
(0.231)\end{array}$ & $\begin{array}{l}-0.179 \\
(0.547)\end{array}$ & $\begin{array}{l}-0.462^{* *} \\
(0.215)\end{array}$ & $\begin{array}{c}0.835 \\
(1.062)\end{array}$ & & $\begin{array}{l}1.250 \\
(0.875)\end{array}$ & & $\begin{array}{l}-0.174 \\
(1.178)\end{array}$ & \\
\hline Financial reform index & $\begin{array}{l}-0.030 \\
(0.109) \\
\end{array}$ & & $\begin{array}{l}-0.063 \\
(0.109) \\
\end{array}$ & & $\begin{array}{c}0.192 \\
(0.142) \\
\end{array}$ & $\begin{array}{l}0.046^{\star \star} \\
(0.021) \\
\end{array}$ & $\begin{array}{c}0.177 \\
(0.108) \\
\end{array}$ & $\begin{array}{r}0.065^{*} \\
(0.036) \\
\end{array}$ & $\begin{array}{c}0.018 \\
(0.185) \\
\end{array}$ & \\
\hline \multicolumn{11}{|l|}{ Product market regulation } \\
\hline $\begin{array}{l}\text { Regulation in seven non-manufacturing } \\
\text { sectors }\end{array}$ & & & & & $\begin{array}{c}0.220 \\
(0.504)\end{array}$ & $\begin{array}{l}-0.782^{* *} \\
(0.314)\end{array}$ & $\begin{array}{c}0.446 \\
(0.452)\end{array}$ & $\begin{array}{l}-0.905^{* *} \\
(0.414) \\
\end{array}$ & $\begin{array}{l}-0.891 \\
(0.862)\end{array}$ & \\
\hline
\end{tabular}

Note: Robust standard errors in parentheses. * ${ }^{* *}$ and ${ }^{* * *}$ denote significance at the $10 \%, 5 \%$ and $1 \%$ significance level. SAVT, SAVP, INVT, INVP, and CA denote the GDP shares of respectively total

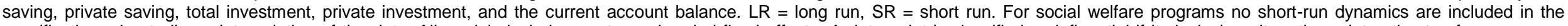

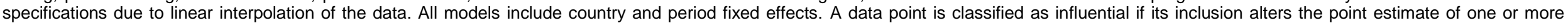
coefficients (excluding dummies) in the baseline specification by more than $1 / 2$ standard error. 
ECO/WKP(2010)71

Table A1.10. The impact of structural policies on saving in OECD countries - alternative specifications

\begin{tabular}{|c|c|c|c|c|}
\hline & SAVT & SAVT & SAVP & SAVP \\
\hline \multicolumn{5}{|l|}{ Long-run relationship } \\
\hline Productivity growth & $\begin{array}{c}0.438 \\
(0.315)\end{array}$ & $\begin{array}{c}0.406 \\
(0.310)\end{array}$ & $\begin{array}{c}0.058 \\
(0.228)\end{array}$ & $\begin{array}{c}0.053 \\
(0.208)\end{array}$ \\
\hline Change in terms of trade & $\begin{array}{c}0.380^{* * *} \\
(0.080)\end{array}$ & $\begin{array}{c}0.398^{\star * *} \\
(0.092)\end{array}$ & $\begin{array}{l}0.138^{\star *} \\
(0.063)\end{array}$ & $\begin{array}{l}0.114^{* *} \\
(0.057)\end{array}$ \\
\hline Real long-term interest rate & $\begin{array}{c}-0.507^{* * *} \\
(0.195)\end{array}$ & $\begin{array}{c}-0.381^{* *} \\
(0.150)\end{array}$ & $\begin{array}{l}-0.345^{*} \\
(0.193)\end{array}$ & $\begin{array}{c}-0.307^{* *} \\
(0.152)\end{array}$ \\
\hline Old-age dependency ratio & $\begin{array}{c}-0.397^{* * *} \\
(0.146)\end{array}$ & $\begin{array}{c}-0.420^{\star * *} \\
(0.156)\end{array}$ & $\begin{array}{l}-0.233 \\
(0.223)\end{array}$ & $\begin{array}{l}-0.285 \\
(0.200)\end{array}$ \\
\hline Youth dependency ratio & $\begin{array}{c}0.052 \\
(0.135)\end{array}$ & $\begin{array}{c}0.137 \\
(0.153)\end{array}$ & $\begin{array}{c}0.243 \\
(0.191)\end{array}$ & $\begin{array}{c}0.266 \\
(0.179)\end{array}$ \\
\hline Government net lending & $\begin{array}{c}0.216^{*} \\
(0.113)\end{array}$ & $\begin{array}{l}0.238^{*} \\
(0.123)\end{array}$ & $\begin{array}{c}-0.704^{\star \star *} \\
(0.106)\end{array}$ & $\begin{array}{c}-0.662^{\star * *} \\
(0.105)\end{array}$ \\
\hline Public social spending, health & $\begin{array}{c}-2.393^{* * *} \\
(0.543)\end{array}$ & $\begin{array}{c}-2.154^{\star * *} \\
(0.552)\end{array}$ & $\begin{array}{c}-1.937^{\star * *} \\
(0.484)\end{array}$ & $\begin{array}{c}-1.758^{* * *} \\
(0.445)\end{array}$ \\
\hline Employment protection legislation (EPL) & $\begin{array}{c}0.584 \\
(0.478)\end{array}$ & $\begin{array}{c}0.866^{*} \\
(0.482)\end{array}$ & $\begin{array}{c}0.781 \\
(0.519)\end{array}$ & $\begin{array}{l}0.937^{*} \\
(0.514)\end{array}$ \\
\hline Financial reform index & $\begin{array}{c}0.026 \\
(0.117)\end{array}$ & & $\begin{array}{c}0.011 \\
(0.109)\end{array}$ & \\
\hline Credit to private sector (\% of GDP) & & $\begin{array}{c}-2.546^{* * *} \\
(0.943)\end{array}$ & & $\begin{array}{l}-1.249 \\
(0.898) \\
\end{array}$ \\
\hline \multicolumn{5}{|l|}{ Short-run dynamics } \\
\hline Error correction parameter & $\begin{array}{c}-0.259^{* * *} \\
(0.042)\end{array}$ & $\begin{array}{c}-0.243^{* * *} \\
(0.043)\end{array}$ & $\begin{array}{c}-0.294^{* * *} \\
(0.049)\end{array}$ & $\begin{array}{c}-0.309^{* * *} \\
(0.047)\end{array}$ \\
\hline$\Sigma \Delta$ Dependent variable & $\begin{array}{c}-0.111^{* *} \\
(0.045)\end{array}$ & $\begin{array}{c}-0.127^{\star \star *} \\
(0.043)\end{array}$ & & \\
\hline$\Sigma \Delta$ Productivity growth & $\begin{array}{c}0.103 \\
(0.065)\end{array}$ & $\begin{array}{c}0.086 \\
(0.058)\end{array}$ & $\begin{array}{l}-0.012 \\
(0.077)\end{array}$ & $\begin{array}{l}-0.011 \\
(0.071)\end{array}$ \\
\hline$\Sigma \Delta$ Change in terms of trade & $\begin{array}{c}0.111^{* * *} \\
(0.016)\end{array}$ & $\begin{array}{c}0.114^{\star * *} \\
(0.015)\end{array}$ & $\begin{array}{l}0.038^{*} \\
(0.021)\end{array}$ & $\begin{array}{c}0.032 \\
(0.020)\end{array}$ \\
\hline$\Sigma \Delta$ Real long-term interest rate & $\begin{array}{l}-0.081^{*} \\
(0.046)\end{array}$ & $\begin{array}{l}-0.070 * \\
(0.036)\end{array}$ & $\begin{array}{l}-0.041 \\
(0.050)\end{array}$ & $\begin{array}{l}-0.036 \\
(0.039)\end{array}$ \\
\hline$\Sigma \Delta$ Old-age dependency ratio & $\begin{array}{c}0.499 \\
(0.439)\end{array}$ & $\begin{array}{c}0.546 \\
(0.456)\end{array}$ & $\begin{array}{l}-0.102 \\
(0.530)\end{array}$ & $\begin{array}{l}-0.042 \\
(0.541)\end{array}$ \\
\hline$\Sigma \Delta$ Youth dependency ratio & $\begin{array}{c}-0.607^{* * *} \\
(0.224)\end{array}$ & $\begin{array}{c}-0.436^{*} \\
(0.231)\end{array}$ & $\begin{array}{c}-0.569^{* *} \\
(0.263)\end{array}$ & $\begin{array}{l}-0.455^{\star} \\
(0.247)\end{array}$ \\
\hline$\Sigma \Delta$ Government net lending & $\begin{array}{c}0.228^{\star * *} \\
(0.027)\end{array}$ & $\begin{array}{c}0.218^{\star * *} \\
(0.028)\end{array}$ & $\begin{array}{c}-0.368^{* * *} \\
(0.043)\end{array}$ & $\begin{array}{c}-0.343^{\star \star *} \\
(0.042)\end{array}$ \\
\hline$\Sigma \Delta$ Credit to private sector (\% of GDP) & & $\begin{array}{c}0.656^{* * *} \\
(0.224)\end{array}$ & & \\
\hline
\end{tabular}

Note: Robust standard errors in parentheses. * ${ }^{* *}$ and ${ }^{* * *}$ denote significance at the $10 \%, 5 \%$ and $1 \%$ significance level. SAVT and SAVP denote the GDP shares of respectively total and private saving. For social welfare programs no short-run dynamics are included in the specifications due to linear interpolation of the data. All models include country and period fixed effects. 
Table A1.11. The impact of structural policies on investment in OECD countries - alternative specifications

\begin{tabular}{|c|c|c|c|c|c|c|}
\hline & INVT & INVT & INVT & INVP & INVP & INVP \\
\hline \multicolumn{7}{|l|}{ Long-run relationship } \\
\hline User cost of capital & $\begin{array}{c}-0.718^{* * *} \\
(0.212)\end{array}$ & $\begin{array}{c}-0.716^{* * *} \\
(0.215)\end{array}$ & $\begin{array}{c}-0.651^{* * *} \\
(0.197)\end{array}$ & $\begin{array}{c}-0.506^{* * *} \\
(0.133)\end{array}$ & $\begin{array}{c}-0.500^{* * *} \\
(0.133)\end{array}$ & $\begin{array}{c}-0.356^{* * *} \\
(0.115)\end{array}$ \\
\hline Productivity growth & $\begin{array}{c}2.982^{\star \star *} \\
(0.896)\end{array}$ & $\begin{array}{c}2.990^{\star * *} \\
(0.891)\end{array}$ & $\begin{array}{c}2.491^{* * *} \\
(0.771)\end{array}$ & $\begin{array}{l}1.976^{* \star *} \\
(0.562)\end{array}$ & $\begin{array}{l}1.967^{\star \star *} \\
(0.560)\end{array}$ & $\begin{array}{l}1.730^{\star * *} \\
(0.454)\end{array}$ \\
\hline Change in population aged $15-64$ & $\begin{array}{c}4.453^{\star * *} \\
(1.459)\end{array}$ & $\begin{array}{c}4.454^{\star * *} \\
(1.452)\end{array}$ & $\begin{array}{c}4.118^{* * *} \\
(1.274)\end{array}$ & $\begin{array}{l}2.359^{* *} \\
(1.001)\end{array}$ & $\begin{array}{l}2.328^{* *} \\
(0.980)\end{array}$ & $\begin{array}{c}2.249^{* * *} \\
(0.842)\end{array}$ \\
\hline Employment protection legislation (EPL) & $\begin{array}{c}1.043 \\
(0.853)\end{array}$ & & $\begin{array}{l}0.645 \\
(0.712)\end{array}$ & $\begin{array}{c}0.745 \\
(0.566)\end{array}$ & & $\begin{array}{c}0.237 \\
(0.476)\end{array}$ \\
\hline EPL on temporary contracts & & $\begin{array}{c}0.654 \\
(0.443)\end{array}$ & & & $\begin{array}{l}0.520^{*} \\
(0.307)\end{array}$ & \\
\hline $\begin{array}{l}\text { Regulation in seven non-manufacturing } \\
\text { sectors }\end{array}$ & $\begin{array}{c}0.360 \\
(0.630)\end{array}$ & $\begin{array}{c}0.400 \\
(0.560)\end{array}$ & $\begin{array}{l}0.715 \\
(0.624)\end{array}$ & $\begin{array}{c}0.609 \\
(0.535)\end{array}$ & $\begin{array}{c}0.544 \\
(0.534)\end{array}$ & $\begin{array}{l}0.958^{*} \\
(0.512)\end{array}$ \\
\hline Financial reform index & $\begin{array}{l}0.351^{*} \\
(0.201)\end{array}$ & $\begin{array}{l}0.344^{*} \\
(0.199)\end{array}$ & & $\begin{array}{l}0.352^{* *} \\
(0.156)\end{array}$ & $\begin{array}{l}0.352^{* *} \\
(0.156)\end{array}$ & \\
\hline Credit to private sector (\% of GDP) & & & $\begin{array}{l}2.339^{* *} \\
(1.085)\end{array}$ & & & $\begin{array}{c}2.080^{* * *} \\
(0.660)\end{array}$ \\
\hline \multicolumn{7}{|l|}{ Short-run dynamics } \\
\hline Error correction parameter & $\begin{array}{c}-0.113^{\star \star \star} \\
(0.024)\end{array}$ & $\begin{array}{c}-0.113^{\star \star *} \\
(0.023)\end{array}$ & $\begin{array}{c}-0.129^{\star \star \star} \\
(0.029)\end{array}$ & $\begin{array}{c}-0.164^{\star * *} \\
(0.034)\end{array}$ & $\begin{array}{c}-0.164^{\star * *} \\
(0.034)\end{array}$ & $\begin{array}{c}-0.181^{* * *} \\
(0.036)\end{array}$ \\
\hline$\Sigma \Delta$ Dependent variable & $\begin{array}{l}0.150^{*} \\
(0.086)\end{array}$ & $\begin{array}{l}0.150^{*} \\
(0.085)\end{array}$ & $\begin{array}{l}0.120 \\
(0.086)\end{array}$ & $\begin{array}{l}0.159^{* *} \\
(0.071)\end{array}$ & $\begin{array}{l}0.160^{\star *} \\
(0.070)\end{array}$ & $\begin{array}{l}0.148^{*} \\
(0.084)\end{array}$ \\
\hline$\Sigma \Delta$ User cost of capital & $\begin{array}{c}0.048^{* * *} \\
(0.018)\end{array}$ & $\begin{array}{l}0.047^{\star *} \\
(0.019)\end{array}$ & $\begin{array}{l}0.050^{\star *} \\
(0.021)\end{array}$ & $\begin{array}{c}-0.086^{* * *} \\
(0.015)\end{array}$ & $\begin{array}{c}-0.086^{* * *} \\
(0.014)\end{array}$ & $\begin{array}{c}-0.055^{\star * \star} \\
(0.020)\end{array}$ \\
\hline$\Sigma \Delta$ Productivity growth & $\begin{array}{c}0.186^{* * *} \\
(0.034)\end{array}$ & $\begin{array}{c}0.187^{\star * *} \\
(0.033)\end{array}$ & $\begin{array}{c}0.180^{\star * *} \\
(0.032)\end{array}$ & $\begin{array}{c}0.211^{* * *} \\
(0.045)\end{array}$ & $\begin{array}{c}0.211^{\star * *} \\
(0.045)\end{array}$ & $\begin{array}{c}0.227^{* * *} \\
(0.049)\end{array}$ \\
\hline$\Sigma \Delta$ Change in population aged $15-64$ & $\begin{array}{c}0.339^{* * *} \\
(0.110)\end{array}$ & $\begin{array}{c}0.339^{* * *} \\
(0.110)\end{array}$ & $\begin{array}{c}0.394^{* * *} \\
(0.114)\end{array}$ & & & \\
\hline$\Sigma \Delta$ Financial reform index & $\begin{array}{l}0.074^{* *} \\
(0.036)\end{array}$ & $\begin{array}{l}0.075^{\star *} \\
(0.036)\end{array}$ & & & & \\
\hline$\Sigma \Delta$ Product market regulation & $\begin{array}{l}-0.109 \\
(0.226)\end{array}$ & $\begin{array}{l}-0.105 \\
(0.226)\end{array}$ & $\begin{array}{l}-0.070 \\
(0.250)\end{array}$ & $\begin{array}{c}-0.440^{* *} \\
(0.197)\end{array}$ & $\begin{array}{c}-0.440^{\star *} \\
(0.198)\end{array}$ & $\begin{array}{c}-0.899^{\star *} \\
(0.413)\end{array}$ \\
\hline
\end{tabular}

Note: Robust standard errors in parentheses. ${ }^{*},{ }^{* *}$ and ${ }^{* * *}$ denote significance at the $10 \%, 5 \%$ and $1 \%$ significance level. INVT and INVP denote the GDP shares of respectively private and total investment. All models include country and period fixed effects. 
ECO/WKP(2010)71

\section{ANNEX 2. DEALING WITH (ALMOST) TIME-INVARIANT EXPLANATORY VARIABLES}

38. While it is possible to estimate a fixed effects model with almost time-invariant variables, this is likely to produce inaccurate point estimates for the coefficients of these variables since the between variance (the variation across countries which is disregarded in a fixed effects regression) accounts for a large share of the total variance of these variables, whereas the within variance (the variation across time which is exploited for inference) only accounts for a small share (for time-invariant explanatory variables the model cannot be estimated at all). Several solutions are available to deal with this issue. First, the country-specific effects could be dropped from the specification, implicitly assuming that what is not already explained by the regressors in the equation - including omitted fixed effects - is randomly distributed and uncorrelated with the regressors. Second, this distribution could be explicitly taken into account by estimating a random effects model. Both solutions add information to the model in order to (better) identify the impact of almost time-invariant variables. However, both will be biased if some regressors are correlated with the country fixed effects, which is likely to be the rule rather than the exception in many applications, including the present one.

39. Plümper and Troeger (2007) propose a new three-step estimator to make inference about the impact of time-invariant and almost time-invariant regressors. However, as pointed out by Greene (2010) and Breusch et al. (2010), the procedure produces downward biased standard errors. Nonetheless, several important insights emerge from the Plümper and Troeger (2007) approach. First, almost-time invariant variables should be treated in the same way as time-invariant ones since they carry similar types of information. Second, even though the fixed-effects model produces unbiased estimates, departing from the fixed-effects model can be reasonable in order to gain efficiency and obtain coefficient estimates with a smaller variance. Third, it is possible to pursue this approach while still controlling at least partially for the presence of country-specific effects.

40. To formalise, let the model be of the following general form:

$$
Y_{i t}=X_{i t} \beta+Z_{i t} \gamma+u_{i}+\varepsilon_{i t}
$$

where $Y_{i t}, u_{i}$ and $\varepsilon_{i t}$ are scalars, $X_{i t}$ and $Z_{i t}$ are row-vectors, and $1 \leq i \leq N$ and $1 \leq t \leq T$. The vector $Z_{i t}$ contains both time-invariant and almost-time invariant variables, while $X_{i t}$ contains the remaining regressors which have sufficient time-variation. The error terms $\varepsilon_{i t}$ are assumed to be centred and uncorrelated with each other and also uncorrelated with both $X_{i t}$ and $Z_{i t}$. The country random effects $u_{i}$ capture cross-country differences in $Y_{i}$ that are not already captured by $X_{i}$ and $Z_{i}$ (where $Y_{i}, X_{i}$ and $Z_{i}$ denote the averages of $Y_{i t}, X_{i t}$ and $Z_{i t}$ over time). It is assumed that the $u_{i}$ follow some centred random distribution and are uncorrelated with all $\varepsilon_{i t}$.

41. To estimate the model, one needs to instrument $Z_{i}$, meaning that a set of variables must be identified that are uncorrelated with the residual $u_{i}+\varepsilon_{i t}$ but correlated with $Z_{i t}$ (for simplicity, variables that are not part of the model are excluded as potential instruments). ${ }^{86}$ If no additional assumption is made

86. Baltagi (2008) discusses the instruments and the GLS correction that can be used to estimate the model in the case of time-invariant $Z$ 's. 
about the correlation between $\left(X_{i t}, Z_{i t}\right)$ and $u_{i}$, the list of potential instruments reduces to $\left(X_{i t}-X_{i}, Z_{i t}-Z_{i}\right)$, from which (non-identifiable) purely time-invariant $Z$ 's are dropped. Therefore, the fixed effects estimator becomes the proper instrumental variables estimator. If it is instead assumed that there is no correlation between $\left(X_{i t}, Z_{i t}\right)$ and $u_{i}$, the between information embedded in $X_{i t}$ and $Z_{i t}$ can be fully exploited. The list of exogenous variables is $\left(X_{i t}, Z_{i t}\right)$ and the optimal linear estimator is the classical random-effects estimator. The random-effects estimator is more efficient than the fixed-effects estimator, but only if this additional assumption is satisfied; otherwise the random-effects estimator is inconsistent and the fixed effects estimator should be preferred.

42. One way to achieve a reasonable consistency-efficiency trade-off between these two extreme alternatives is to use only some of the cross-sectional information embedded in $X_{i t}$ and $Z_{i t}$. Assuming that sufficiently good inference on $\beta$ can be made with the fixed effects estimator, additional information on $X_{i t}$ is not necessary, especially if it is also believed that $X_{i t}$ is more likely to be correlated with the $u_{i}$ than $Z_{i t}$ is. Since $\gamma$ is the problematic parameter and since one wishes to exploit the cross-country variations of $Z_{i t}$, using $Z_{i t}$ as an instrument, but not necessarily directly $X_{i t}$, looks natural.

43. Following these ideas, this box proposes two alternative estimators to obtain an estimate of the coefficient vector $\gamma$. The work builds upon the results of Breusch et al. (2010), who show that in the case of strictly time-invariant variables the estimator proposed by Plümper and Troeger (2007) is in fact an instrumental variable estimator. Defining $\tilde{X}_{i t}$ as the projection of $X_{i t}$ onto the orthogonal of $Z_{i t}$ and the country-dummies (i.e. the residual of a regression of $X_{i t}$ on $Z_{i t}$ and county dummies), ${ }^{87}$ then the set of instrumental variables could be either $\left(X_{i t}-X_{i}, Z_{i t}\right)$ or $\left(\tilde{X}_{i t}, Z_{i t}\right)$. Both sets of instruments could be used to estimate the model with generalised two-stage least squares (Baltagi, 2008, p. 123). Both sets use the between information for $Z_{i t}$, but not for $X_{i t}$. To be consistent, it must be assumed that the $Z_{i t}$ are uncorrelated with the unobserved $u_{i}$, but no assumption is needed with respect to the joint distribution of $u_{i}$ and $X_{i t}$. In this regard, the two alternative estimators lie in between the random-effects and the fixed-effects estimators. The second set of instruments was preferred in the application since it produces slightly more robust results than the first one. ${ }^{88}$ Indeed, the generalized two-stage least squares approach with instruments $\left(\tilde{X}_{i t}, Z_{i t}\right)$ has the additional desirable property that the estimate of $\beta$ is exactly equal to that obtained from the fixed-effects regression. Hence, if $\operatorname{cov}\left(Z_{i t}, u_{i}\right)$ is in fact non-zero, then only the estimate of $\gamma$ is biased, whereas the estimate of $\beta$ is sheltered from this risk.

44. While this estimator resembles that of Plümper and Troeger (2007) in its spirit, it is different in two important respects. First, the standard errors are trustworthy and, second, the feasible GLS method ensures higher efficiency. Even in the case when $\operatorname{cov}\left(Z_{i t}, u_{i}\right)$ is non-zero, but remains small, the additional information used by the proposed estimator can still improve the estimate of $\gamma$ relative to the fixed-effects estimator. Indeed, as demonstrated by Plümper and Troeger (2007) with some simulations, a small bias can be a fair cost for a much lower variance in terms of the root mean square error criterion. ${ }^{89}$

87. If the entire $Z_{i t}$ is time invariant, then $\tilde{X}_{i t}$ simply reduces to $\tilde{X}_{i t}=X_{i t}-X_{i}$.

88. Both approaches yield comparable conclusions, however.

89. The mean square error of an estimator equals its variance plus the square of its bias. 
ECO/WKP(2010)71

\section{BIBLIOGRAPHY}

Baltagi B. H. (2008), Econometric Analysis of Panel Data, Fourth Edition, John Wiley \& Sons, West Sussex.

Breusch, T. et al. (2010), “On the Fixed Effects Vector Decomposition”, Munich Personnal Repec Archive Paper No. 21452.

Greene, W. (2010), "Fixed Effects Vector Decomposition: A Magical Solution to the Problem of Time Invariant Variables in Fixed Effects Models?", mimeo, New York University.

Plümper, T. and V. Troeger (2007), "Efficient Estimation of Time-Invariant and Rarely Changing Variables in Finite Sample Panel Analyses with Unit Fixed Effects", Political Analysis, Vol. 15, pp. 124-139. 


\section{WORKING PAPERS}

The full series of Economics Department Working Papers can be consulted at www.oecd.org/eco/workingpapers/

814. Towards a less distortive and more efficient tax system in Portugal (November 2010) by Alvaro Pina

813. Are global imbalances sustainable? Shedding further light on the causes of current account reversals

(November 2010) by Luiz de Mello, Pier Carlo Padoan, Linda Rousová

812. Turkey's improving integration with the global capital market: Impacts on risk premia and capital costs

(November 2010) by Rauf Gönenç, Saygin Şahinöz, Özge Tuncel

811. Trade linkages in the OECD trade system

(October 2010) by Jérôme Brézillon, Stéphanie Guichard and Dave Turner

810. Enhancing the effectiveness of social policies in Indonesia

(October 2010) by Margherita Comola and Luiz de Mello

809. Tackling the infrastructure challenge in Indonesia

(October 2010) by Mauro Pisu

808. Phasing out energy subsidies in Indonesia

(October 2010) by Annabelle Mourougane

807. Implementing cost-effective policies in the United States to mitigate climate change (October 2010) by David Carey

806. Restoring fiscal sustainability in the United States

(October 2010) by Patrick Lenain, Bob Hagemann and David Carey

805. Norway: Sustainable development: climate change and fisheries policies (September 2010) by Paul O’Brien

804. Netherlands: How the transport system can contribute to better economic and environmental outcomes

(September 2010) by Tomasz Koźluk

803. Public-private partnerships and investment in infrastructure

(September 2010) by Sónia Araújo and Douglas Sutherland

802. Sustaining the momentum of fiscal reform

(September 2010) by Colin Forthun and Robert Hagemann

801. The consequences of banking crises for public debt

(September 2010) by Davide Furceri and Aleksandra Zdzienicka 
800. A simulation model of federal, provincial and territorial government accounts for the analysis of fiscal-consolidation strategies in Canada

(September 2010) by Yvan Guillemette

799. Product market regulation: extending the analysis beyond OECD countries (October 2010) by Anita Wölfl, Isabelle Wanner, Oliver Röhn, Giuseppe Nicoletti

798. Korea's green growth strategy: mitigating climate change and developing new growth engines (July 2010) by Randall S. Jones and Byungseo Yoo

797. Health-care reform in Korea

(July 2010) by Randall S. Jones

796. The Korean financial system: overcoming the global financial crisis and addressing remaining problems

(July 2010) by Masahiko Tsutsumi, Randall S. Jones and Thomas F. Cargill

795. Are global imbalances sustainable? Post-crisis scenarios

(July 2010) by Luiz de Mello and Pier Carlo Padoan

794. Is there a case for carbon-based border tax adjustment? An applied general equilibrium analysis (July 2010) by Jean-Marc Burniaux, Jean Chateau and Romain Duval

793. Promoting potential growth: The role of structural reform

(July 2010) by Luiz de Mello and Pier Carlo Padoan

792. Catching-up and inflation in Europe: Balassa-Samuelson, Engel's law and other culprits (July 2010) by Balázs Égert

791. Do product market regulations in upstream sectors curb productivity growth? Panel data evidence for OECD countries (July 2010) by Renaud Bourlès, Gilbert Cette, Jimmy Lopez, Jacques Mairesse, Giuseppe Nicoletti

790. Preparing for Euro adoption in Poland

(July 2010) by Rafal Kierzenkowski

789. Gauging the impact of higher capital and oil costs on potential output (June 2010) by Boris Cournède

788. The German banking system: lessons from the financial crisis (June 2010) by Felix Hüfner

787. Measuring competition in Slovenian industries - estimation of mark-ups (June 2010) by Margit Molnar

786. Enhancing financial stability through better regulation in Hungary (June 2010) by Margit Molnar

785. Chile: Boosting productivity growth by strengthening competition, entrepreneurship and innovation (June 2010) by Cyrille Schwellnus 